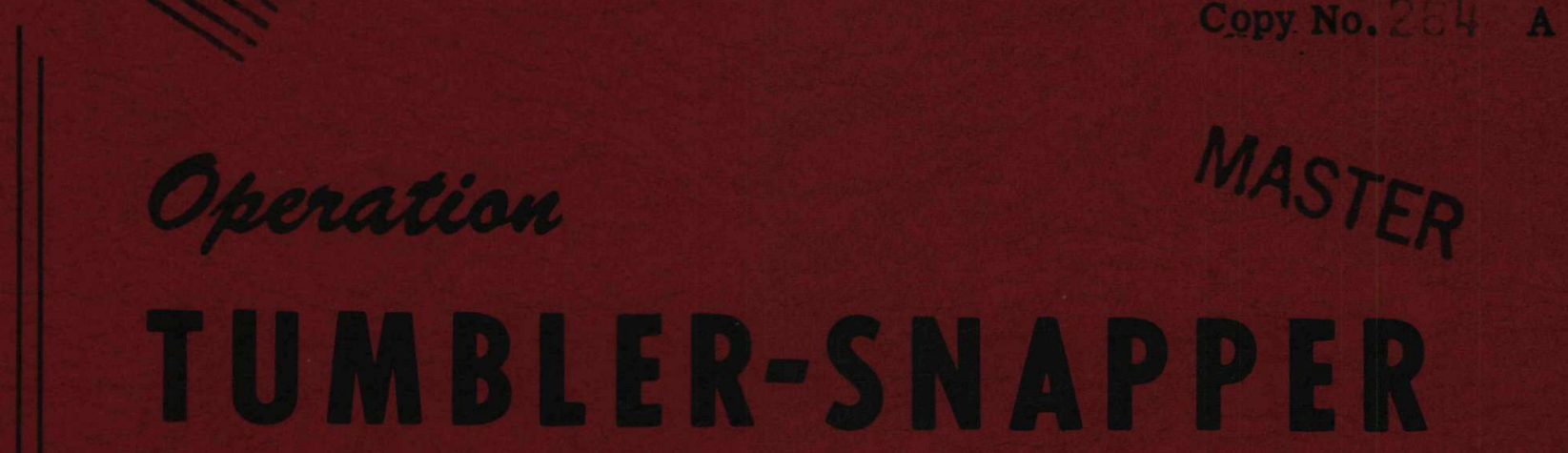

NEVADA PROVING GROUNDS

April - June, 1952

Project 8.3

THERMAL RADLATION FROM A NUCLEAR DETONATION
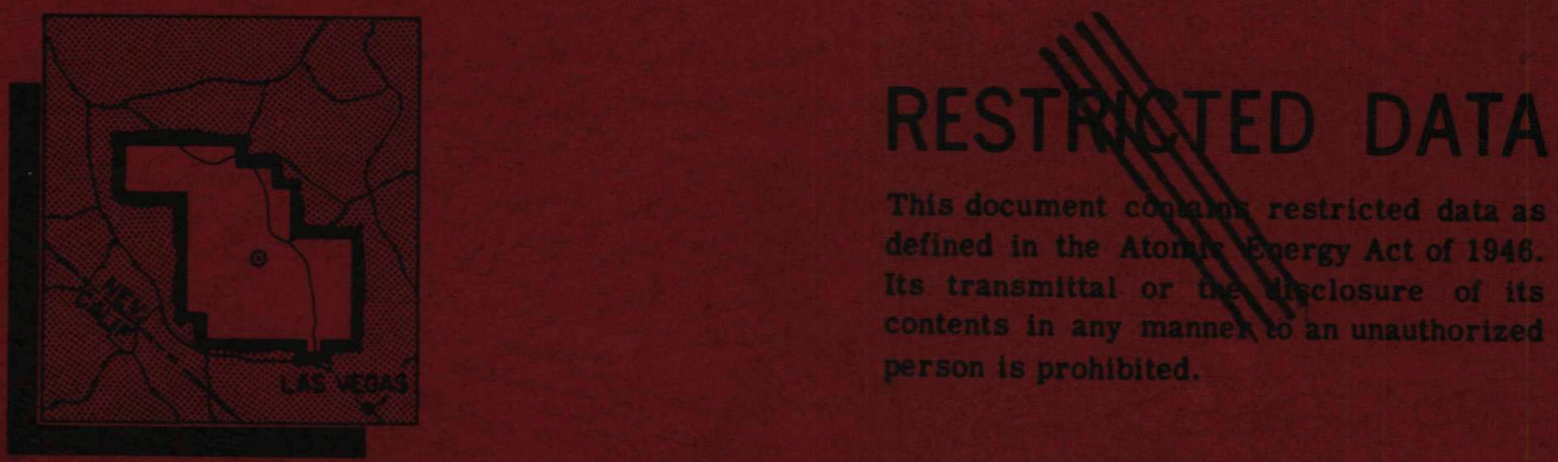

This document conthestricted data as defined in the Atorly Exergy Act of 1946. Its transmittal or th Mtsclosure of its contents in any mannek to an unauthorized person is prohibited.

ARMED FORCES SPECIAL WEAPONS PROJECT WASHINGTON, D.C.

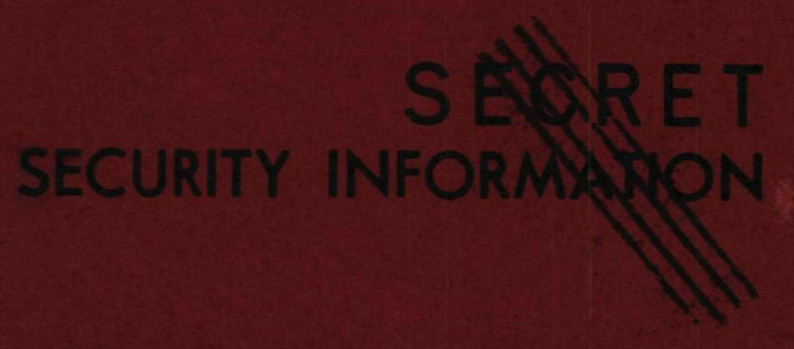




\section{DISCLAIMER}

This report was prepared as an account of work sponsored by an agency of the United States Government. Neither the United States Government nor any agency Thereof, nor any of their employees, makes any warranty, express or implied, or assumes any legal liability or responsibility for the accuracy, completeness, or usefulness of any information, apparatus, product, or process disclosed, or represents that its use would not infringe privately owned rights. Reference herein to any specific commercial product, process, or service by trade name, trademark, manufacturer, or otherwise does not necessarily constitute or imply its endorsement, recommendation, or favoring by the United States Government or any agency thereof. The views and opinions of authors expressed herein do not necessarily state or reflect those of the United States Government or any agency thereof. 


\section{DISCLAIMER}

Portions of this document may be illegible in electronic image products. Images are produced from the best available original document. 
This document consists of 109 pages

- No. $2 C 4$ of 340 copies, Series A

OPERATION TUMBLER-SNAPPER

Project 8.3

\title{
THERMAL RADIATION FROM A NUCLEAR DETONATION
}

\author{
REPORT TO THE TEST DIRECTOR
}

by
A. Broido
C. P. Butler
R. P. Day
R. W. Hillendahl
S. B. Martin
A. B. Willoughby

March 1953

CLASSIFICATION CANCELLED. DATE $4 / 27 / 62$ For The Atomic Energy Commission - Tr ir Oanack Chief, Declassification Brancti $D_{4}$

U. S. Naval Radiological Defense Laboratory

San Francisco 24, California 


\section{Reproduced Direct from Manuscript Copy by AEC Technical Information Service \\ Oak Ridge, Tennessee}

Inquiries relative to this report may be made to Chief, Armed Forces Special Weapons Project P. O. Box 2610

Washington, D. C.

If this report is no longer needed, return to AEC Technical Information Service

P. O. Box 401

Oak Ridge, Tennessee 


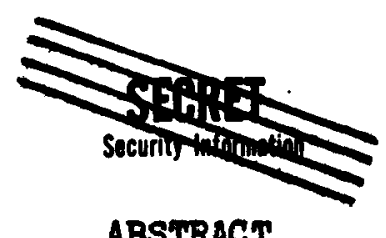

ABSTRACT

Yeasurements of thermal radiation from four molear dotonations at Operation TUMBLER-SNAPPER are described. Data were obtained from stations along the thermal line from ground zero to $9000 \mathrm{ft}$, along the U. S. Forest Service (USFS) Iine from 11,000 to $20,000 \mathrm{ft}$, from certain stations where aireraft were parked, and from the drop aircraft. The instruments used were similar to those used in previons field operations, with the exception of a few new instruments for measuring directly the rate of delivery of the thermal energy. Instruments included disk calorimeters, passive receivers, photronic cells, radiometers, and sphere calorimeters.

In addition to measurements of the total thermal energy received as a function of distance, elevation, and field of view of the measuring device, measurements were made of the thermal pulse shape, the spectral distribution, and the energy reflected from the ground. The results show the relationship between weapon yleld and such factors as total thermal energy at any distance, maximum intensity and duration of the thermal

- pulse, thermal efficiency of the weapons (ratio of thermal field to totel yield as determined by radiochemical analysis), and the amount of local obscuration caused by the thermal radiation and blast wave.

Although uncertainties are such that the range of weapon yields (1-30 KT) is not sufficiently great to allow accurate assessment of scaling laws, linear scaling of thermal efficiency and third power time scaling of the pulse do not seem to apply. The data reported here indicate a decrease in thermal efficiency with increasing weapon $\mathrm{jleld}$, ranging from about 44 per cent at 1 KT to about 34 per cent at $30 \mathrm{KT}$. The time to the second maximum of the thermal pulse ranges fram approximately 100 msec for a 1 KT weapon to about 200 msec for a $30 \mathrm{kT}$ dotonation.

The spectral measurements indicate that the thermal radiation arriving at the measuring stations peaks in the visible region, with about 10 per cent of the energy in the wave length region belor 3600 \& and about 25 per cent in wave lengths beyond $9500 \AA$. Total thermal rediation measurements made near ground level indicate that, even before the arrival of the shock wave, serious obscuration is prochuced by such effects of the radiation as "popcorning" of sand, and smoke produced by the burning of ground litter. The thermal energy received by aircraft flying above the detonation was appreciably greater than that received at equiralent distances along the ground. This increase is primarily de to reflection by the ground.
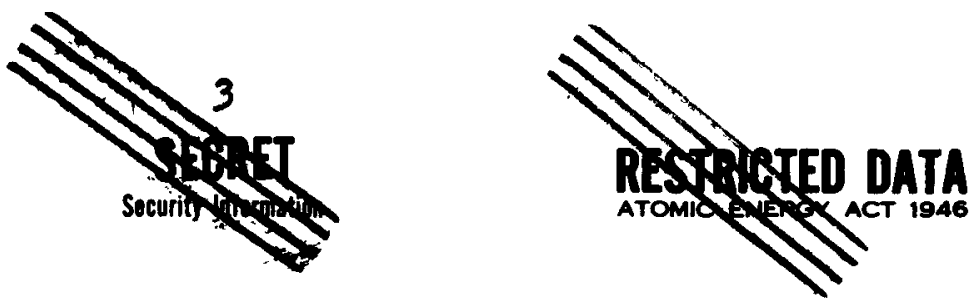


$$
x^{\prime}
$$

b 


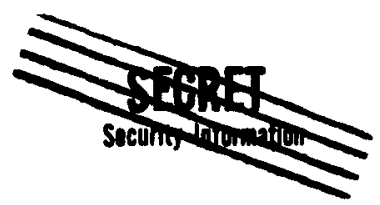

PRERACE

The U. S. Naval Radiological Defense Iaboratory (USNRDL), participated in Projects 8.2 and 8.3 of Operation TUMBLER-SNAPPER.

The first of these projects concerned measurements of the temperatures produced in air near the earth's surface in the vicinity of a muclear detonation. The other two each involved measurements of thermal radiation anitted in anch a detonation. The work performed under Project 8.2 is reported elsewhere. However, no attempt was made to distinguish between measurements made for Projects 8.3 and 8.38 , and all thermal radiation measurements are included in this report.

This report includes results obtained fron the analysis of data up to 15 Angust 1952. Also included for comparison purposes are results from simflar neasurements made during Operation BUSTER. It is expected that the results given are final. With a few minor exceptions, they include all data taken in these operations.

\section{- ACKNOWLEDCUENTS}

Project 8.3 of Operation TUMBLER-SNAPPER was carried out under the direction of A. Guthrie, Project Officer. The successful completion of the project was due to the cooperation and unstinted efforts of many individuals at the USNRDL.

The assiatance of R. L. Hopton, D. C. Gardenhire, CDR, USN, and J. R. Michols, AFC, USN, in the laboratory phases of the project is gratefully acknowledged. In addition, J. R. Nichols contributed substantially to the fleld construction work in his capacity as Field Construction Chief at the Nevada Proving Grounds. A. L. Greig and F. I. Iaughridge assisted in certain technical aspects of the project, both in the laboratory and in the fleld.

It is a pleasure to acknowledge the assistance and enconragement of P. C. Tompkins, Scientific Director, USIRDL. The assistance rendered by personnel of the Test Command contributed substantially to the success of the project.
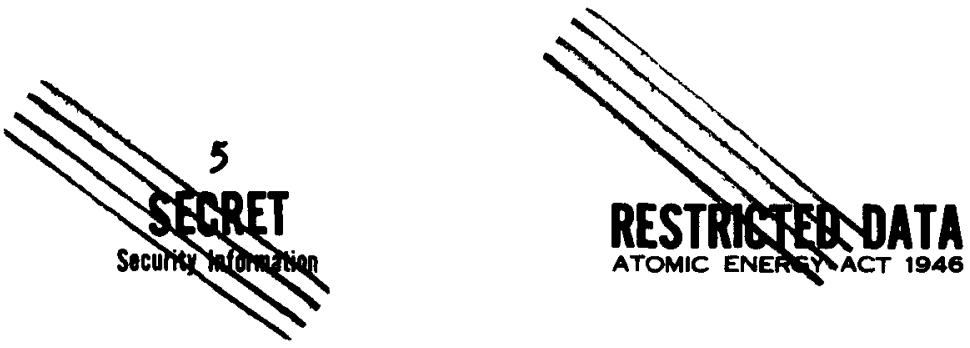
ABSTRACT. - . . . . . . . . . . . . . . . . . 3

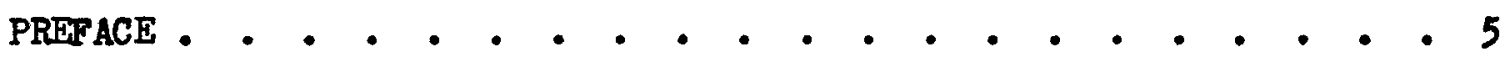

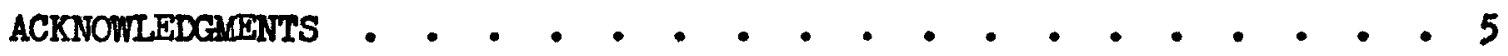

CHAPTER 1 INTRODUCTION. - . - . - . - . - . . - . 13

1.1 Historical . . . . . . . . . . . 13

1.2 Objectives . . . . . . . . . . . 14

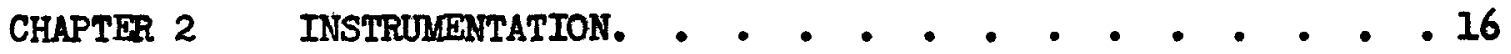

2.1 Make-up and.Location of Stations . . . . . 16

2.2 Disk Calorimeters . . . . . . . . . . . 21

2.2 .1 Description . . . . . . . . . 21

2.2 .2 Use as an Intensity Derice . . . . . 23

2.3 Disk Radiometer. . . . . . . . . . . . 26

2.3.1 Historical. . . . . . . . . . 26

2.3.2 Description of the Instrument . . . . 27

2.3.3 Calibration of the Disk Radiometer. . . 27

2.4 Fino-wire Radiameter . . . . . . . . . 29

2.4.1 Deseription . . . . . . . . . 29

2.4 .2 Theory . . . . . . . . . 29

2.5 Passive-receiver Panels . . . . . . . 32

2.6 Sphere Calorimeters . . . . . . . . 34

2.7 Circuits . . . . : . . . . . . 36

2.8 Mounting............ . . ... .66

chapter 3 calibration - . . . . . . . . . . . . . 40

3.1 General . . . . . . . . . . . 40

3.2 Thermal Calibrations . . . . . . . . 40

3.3 Electrical Calibrations . . . . . . . . . 41

3.4 Field Calorimeters. . . . . . . . . . 43

3.5 Radiometers . . . . . . . . . . . 46

3.6 Passive Receivers............ 47

CHAPTER 4 RESULTS . . . . . . . . . . . . . . . . 49

4.1 General ............... 49

4.2 Calorimeters. . . . . . . . . . 49

4.3 Ractioneters............ 52

4.4 Passivo Receivers... . . . . . . 53

4.5 Sphere Calorimeters . . . . . . . . 60

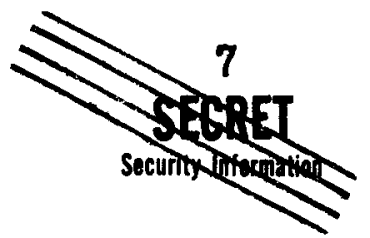


CHAPTER 5 DISCUSSION OF RESULTS . . . . . . . . . . 61

5.1 Calorimeters.............. 61

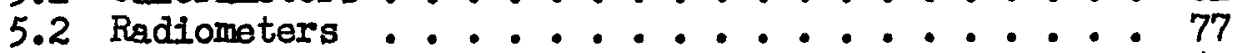

5.3 Spectral Energy Distribution......... 81

5.4 Local Obscuration: The Effect of Elevation of

Measuring Instrument. . . . . . . . . . . 81
5.5 Field of View . . . . . . . . . . . 88
5.6 Passive Receivers . . . . . . . . . . . 90
5.7 Shielding of Recorder Cables . . . . . . . . . 91
5.8 Conclusions . . . . . . . . . . . . . . . . . . . 92
5.9 Recommendations . . . 93

APPENDIX A MEASUREMENT OF THERMAL RADIATION INCIDENT UPON PARKED

AIRCRAFT ................... 95

APPENDIX B MEASUREMEAT OF THERMAL RADIATION INCIDENT ON DROP

AIRCRAFT .................. 97

APPENDIX C REFLECTIVITY OF NEVADA PROVING GROUNDS SOILS . . . . 99

BIBLIOGRAPHY ........................... 101 


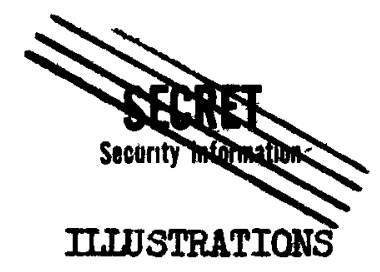

CHAPTER 2 INSTRUMENTATION

2.1 Isometric Drawing of a Typical Station . - . 19

2.2 Schematic Station Lajout T-7 Area . . . 20

2.3 Schematic Station Layout, F Area. . . . . 21

2.4 Cross Section of Field Calorimeter . . . . 22

2.5 Transmission Curves of Quartz and Corning Filters 9-54 and 0-52. . . . . . . 24

2.6 Transmission Curres of Corning Filters 3-69,

2.7 Cross Section of Disk Radiometer. . . . . . 28

2.8 Cross Section of Fine-wire Radiometer . . . 30

2.9 Typical Calibration Curves for Passire

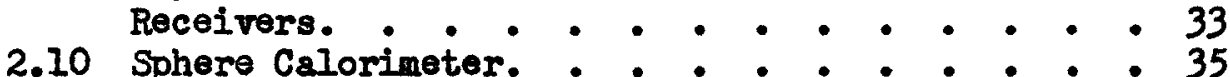

2.11 Circuit Diagram of Typical Instrument Station. 37

2.12 Typical Ground Level Installation. - . . . . 38

2.13 Trpical 10-ft Installation . . . . . . . 39

2.14 Typical 50-ft Installation . . . . . . . 39

2.15 Typieal Station. . . . . . . . . . . 39

CHAPTER 3 CALIBRATION

3.1 Wiring Diagram of Electrical Test Set . . . 42

3.2 Sample Calibration Record Obtained with Test Set. 43

CHAPTER 5 DISCUSSION OF RESULTS

5.1 Energy (Corrected for Atmospheric Attenuation)

vs Slant Range, Shot 1. Calorimeters and Foils . 62

5.2 Fnergy (Corrected for Atmospheric Attenuation) vs Slant Range, Shot 2. Calorimeters and Foils . 63

5.3 Energy (Corrected for Atmospheric Attenuation) vs Slant Range, Shot 3 Calorimeters and Foils . 64

5.4 Energy (Corrected for Atmospheric Attenuation) vs Slant Range, (Shot 4. Calorimeters and Foils, 65

5.5 Typical IndividuaI line Intensity Curves, Shot 3. 67

5.6 Typical Indiviqual Time Intensity Curres, Shot 3. 68

5.7 Typical Individual Time Intensity Curves, Shot 3. 69

5.8 Typical Individual Time Intensity Curves. Shot 3. 70

5.9 Per Cent of Total Energy vs Time for shots I through 4 Operation IUNBLER-SNAPPER. 71

5.10 Normalized Intensity vs Time Ior Shots I through 4.) Operation TUMBLER-SNAPPER $\cdot . \cdot 72$

5.11 Normalized Intensity vs Time Ior Shots Baker (through Easy) Operation BUSTER. - 13
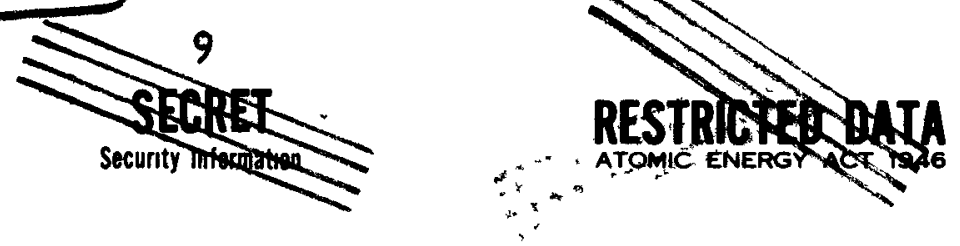


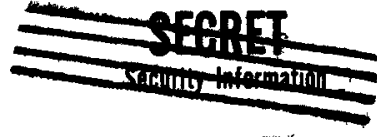

5.12 Energy (Corrected for Atmospheric Attenuation) per KT vs Slant Range for Operation TUMBLERSNAPPER, Shots 1 through 4, and Operation BUSTER, Shots Charlie through Easy . . . . 74

5.13 Thermal Yield vs Total Yield for Operation TUMBLER, Shots 1 through 4 and Operation BUSTER, Shots Baker through Easy. . . . . . . 75

5.14 Thermal Efficiency vs Total Yield for Operation TUMBLER, Shots 1 through 4 and Operation BUSTER, Shots Baker through Easy.

5.15 Intensity-rs-time Curves from Various Instruments, Shot 2. . . . . . . . . . 78

5.16 Intensity-vs-time Curves from Various Instruments, Shot 2S . . . . . . . . . . . 79

5.17 Intensity-rs-time Curves from Various Instruments, Shot 4. . . . . . . . . . . . 80

5.18 Intensity-vs-time curves for Calorimeters Used in Spectral Investigation, Shot 3. . . . . . 82

5.19 Intensity-rs-time Curves for Calorimeters Used in Spectral Investigation Shot 4. . . . . . 83

5.20 Attenuation Due to Local Obscuration for Air) Bursts . . . . . . . . . . 84

5.21 Energy vs Time for 0 and 10-ft Elevations, Station 7-204, (Shot 3) . . . . . . 85

5.22 Energy vs Time for 0 and 50-ft Elevations, Station 7-204 (shot 4 . . . . . . 86

5.23 Fnergy vs Time for 0 and 50-ft Flevations, Station 7-208, Shot 4. . . . . . . . 87

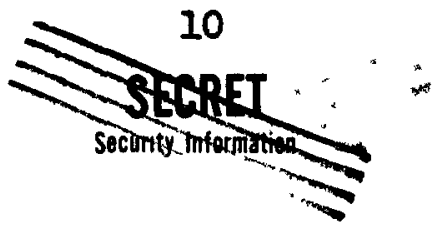




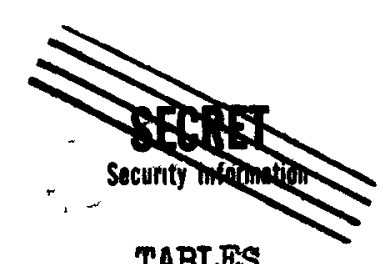

TABLES

CHAPTER 2 INSTRUMENTATION

CHAPTER 3 CALIBRATION

2.1 Station Locations, Shot 1 . . . . . . 17

2.2 Station Locations, Shot 2 . . . . . . . 17

2.3 Station Locations, Shot 3 . - . . . . 18

2.4 Station Locations, Shot 4 . - . . - 18

2.5 Galvanometer Deflections for Various Energies
and Disk Thicknesses . . . . . . . 23

3.1 Thermal Calibration Factors for Disk

Calorimeters. . . . . . . . . . 45

3.2 Calibration Factors for Disk Radiometers (Field). 47

CHAPTER 4 RESULTS

4.I Calorimeter Results, Shot 1. . . . . . 50

4.2 Calorimeter Results, Shot 2. : : : : : 50

4.3 Calorimeter Results, Shot 3. . . . . . . . 51

4.4 Calorimeter Results, Shot 4. . . . . 52

4.5 Disk Radiometer Results.. . . . . 53

4.6 Passive-receiver Results, Shot 1 . . . . . 54

4.7 Passive-receiver Results, Shot 2. . . . . . 56

4.8 Passivo-receivor Results, Shot 3. . . . . . 57

4.9 Passive-receiver Results, Shot 4 . • . . 59

CHAPTER 5 DISCUSSION OF RESULTS

5.1 Total Yields for Operations BUSTER and

TUMBLER-SNAPRER

5.2 Per Cent of Total Energy in the Transmission

Range of the Filters Used in Operation

TUMBLER-SNAPPER. . . . . . . . . . 81

5.3 Effect of Field of View . . . . . . . . 88

5.4 Mean Ratios of Energy Values of Each Indicator to Energy Value of Panel. . . . . . . . 91

APPENDIX A MEASUREMENT OF THERMAL RADIATION INCIDENT UPON PARKED AIRCRAFT

A.1 TUMBLER-SNAPPER Calorimeter Data: WADC Airplanes on Ground. - . • . . . . • . 96
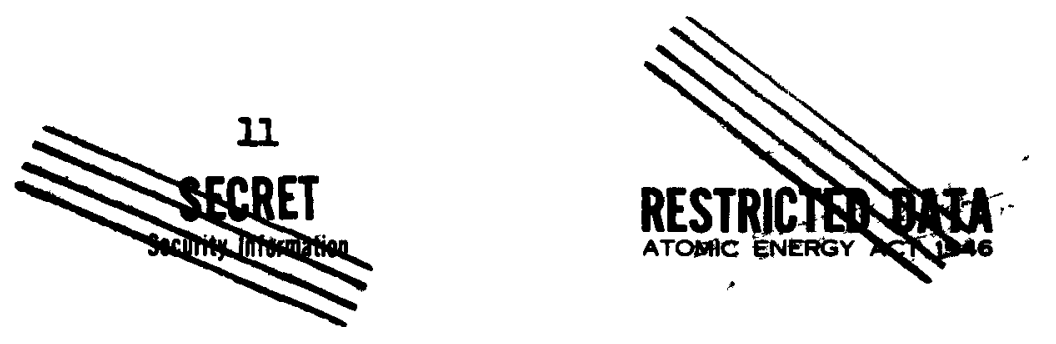


\section{SECD:}

APPENDIX B MEASUREMENT OF THERMAL RADTATION INCIDENT ON DROP AIRCRAFT

B.I TUMBLER-SNAPPER Calorimeter Data: B-50

in Flight over Detonation . . . . . . . 97

APPENDIX C REFLECTIVITY OF NEVADA PROVING GROUNDS SOIIS

C.1 Reflectivity of Soils. . . . . . . . 100 


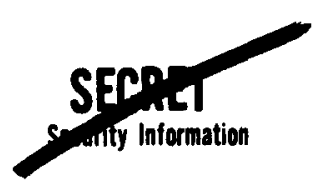

CHAPTER 1

INIROSWUTION

\subsection{HISTORICAL}

The thermal radiation produced during a muclear detonation provides one of the principal methods for the dissipation of the trenendous quantities of energy released. Consequently, it constitutes one of the prine sources of damage produced by such a detonation. Therefore, in any consideration of the effects of a maclear weapon certain characteristics of the thermal radiation emitted are of considerable interest.

Anong the characteristics on which information is needed are the total thermal energy, the time variation of the energy, and the spectral quality of the energy, all expressed as functions of distance from the detonation. Some measurements of these characteristics rere attempted at nearly all previous muclear weapons tests. However, the detonations during most of the previous operations were from towers. The obscuring dust produced by detonations near the ground greatly complicated the results obtained during these operations and thus prevented the accumulation of sufficient data for accurate extrapolation and generalization of the thermal output of the muclear weapon.

Operations CROSSROADS and BUSTER were the only previous operations curing wich extensive thermal measurements were made on air bursts. It Operation CROSSROADS very questionable results were obtained; for example, the thermal energy turned out to be greater than the total energy. Thus, at only one operation prior to the IULALER-SMAPPER tests have data been obtained wich could be readily interpreted. It was important, therefore, to make additional thermal measurements under a variety of conditions and for several detonations in order to check existing theories, to permit the derivation of new theories, and, in general, to improve the chances of successful prediction of results of future detonations, particularly of very much larger weapons than have been detonated to date.

Even if one is able to eliminate the effect of the shock wave in prodacing obscuration of the thermal radiation, great care mast be taken in the interpretation of thermal data obtained relatively close to ground zero. Measurements obtained at Operation GREEWHOUSE bJ U.S. Naval Radiological Defense Iaboratory (USkRDL) personne12/ indicated the presence of obscuring material at times and distances such that it appeared questionable that the obscuration yas produced by the blast wave. Photographs taken during Operation BUSTER3 show that the incident thermal radiation, through the production of smoke and through "popcorning" of the sanc, caused a high degree of local obscuration before the arrival of the blast
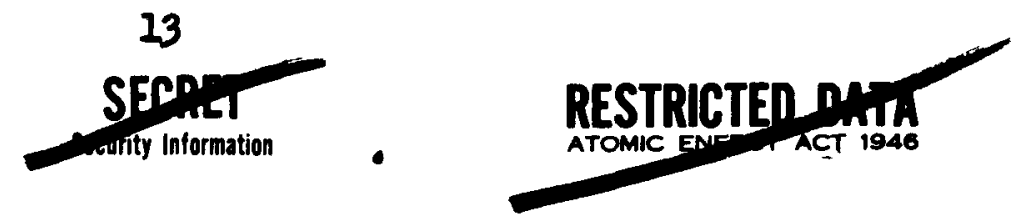


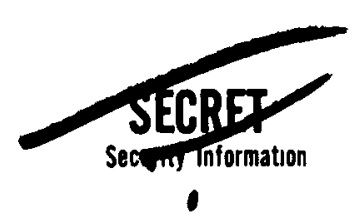

wave. Thus, in any field study of the eff iss of thermal radiation, it becomes advisable to make thermal measurements at stations at which these effects are being investigated.

When Project 8.3 was first approved (as Project 8.3 of Dperation SinaPlar), It had as its immediate objective tne measurement of the charwoteristics of thermal radiation at certain stations at which the effects of this radiation were being determined - primarily, on forest fuels, by U.S. Forest Service personnel, and on parked aircraft, by U.S. Air Force personnel. When Operation TUMBLER was first planned, USNRDL personnel were asked to make measurements of the air temperatures in the vicinity of the TULBLER detonations (see Final Report4/, Operation TUMBLFR, Project 8.2). At the same time Project 8.3 was approved to measure the incident thermal flux at the air temperature stations in order to permit the correlation of thermal with air temperature measurements.

The extensive instrumentation for the air temperature measurement progran provided an excellent opportunity for the measurement of many parameters concerning the thermal radiation field not previously investigated. For example, the 55-ft steel towers erected for the temperature measurements provided an opportunity for the measurement of the incident thermal radiation as a function of the elevation of the measuring instrument. Later an extreme check on the importance of this parameter was afforded when Project 8.3 was invited to instrument one of the drop aircraft. Unfortunately, the short period of time available for preparation, and the utilization of mach of the manpower of the Thermal Radiation Branch, USNRDL, in Project 8.2 work prevented the full utilization of the excellent opportunities afforded.

\subsection{OBJECTIVES}

The primary objective of Project 8.3 was to measure the total thermal radiation and the intensity-time relationship of the radiation as functions of distance from the detonation. More particularly, the objectives were:

1. To measure the total thermal flux and the time-intensity relationship as functions of distance from the detonations, as functions of the elevation of the measuring instruments, and as functions of the local obscuration caused by dust and smoke in support of Project 8.2 air termerature measurements.

2. To measure, in cooperation with Wright Air Development Center (wADC), the incident thermal flux at various locations where the effects of the maclear detonations upon parked aircraft were being investigated.

3. To measure the incident thermal flux at various locations at wich the effects of thermal radiation upon forest fuels were being atudied.
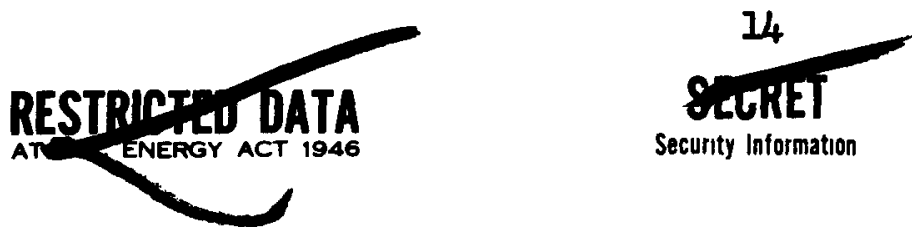


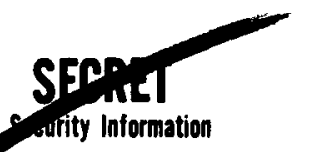

4. To measure the incident thermal flux from the drop aireraft in support of the safety program for the dropping of nuclear weapons.

5. To obtain a rough indication of the spectral breakdown of the thermal radiation by the ase of various Corning glass filters to split the energy into broad spectral reglons.

6. To measure the effect of thermal radiation upon certain material indicators in order to obtain an indication of the effective thermal onergy dose as distinguished from the actual thermal energy incident as measured by the calorimetric instruments.

7. To obtain additional data for purposes of checking proposed scaling laws for thernal radiation and for extrapolation to larger weapons.

8. To measure the thermal radiation received at various stations as a function of the field of Flew of the measuring device.

9. To obtain a very rough approximation of the amount of radiation absorbed and reflected by the ground by measuring both the incident and reflected radiation. Among other things, it was hoped that these measurements could give an indication of the amount of heating of the surface, and thus of the adjacent air. 


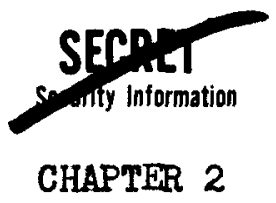

INSTRUMENTATION

\subsection{MAKE-UP AND LOCATION OF STATIONS}

During Operation TUMBLER-SNAPPER measurements of thermal radiation were attempted with severel types of instruments. Prime reliance was placed on the disk calorimeter which had proven successful curing Operations GREBWHOUSE and BOSTER. Weston photronic cells were again used to measure the initial appearance of the thermal radiation.

Since there are several advantages to recording directly the intensity-rs-time pulse obtained during a nuclear detonation, the opportunity was taken to test certain instruments, which, it was hoped, would have a time constant short enough to record intensity directly and yet would be rugged enough to survive the high intensities expected. As only a limited number of recorders were available, additional measurements were attempted with devices which were self-recording. Two types of such devices rere used: panels of blackened metal foils similar to those used previously by USNRDL, and modifications of the black-ball gas calorimeter used with some success during Operation BUSTER by the Naval Research Laboratory (NRL).

The thermal measurements made in connection with the air temperature measurements of Project 8.2, were made on, or adjacent to, the 55-ft steel towers provided for the Project. These towers were located at stations ranging from ground zero to $9000 \mathrm{ft}$ from ground zero. For Shots 3 and 4 measurements made at six U.S. Forest Service, Project 8.I, stations extended the range of measurements out to 20,000 ft from ground zero.

(For each of the three shots in the $\mathrm{T}-7$ Area) seven disk calorimeters were given to WADC personnel for thermal measurefients at Project 3.1 stations. Although these instruments were made and calibrated by Project 8.3 personnel, the installation and recording of data were accomplished by Project 3.1 personnel. Finally, three disk calorimeters were mounted in the B-50 bomber which served as drop plane for several of the detonations. The instruments were installed and operated by members of the 4925th Test Group (Atomic), but the records were turned over to Project 8.3 personnel for analysis.

The make-up and location of the stations at which thermal instramentation was mounted by Project 8.3 are sumarized in Tables 2.1 through 2.4. A plot-plan of a troical station is given in Fig. 2.1. Schematic station layouts for the $1-7$ and $F$ Areas are shown in Figs. 2.2 and 2.3, respectively.

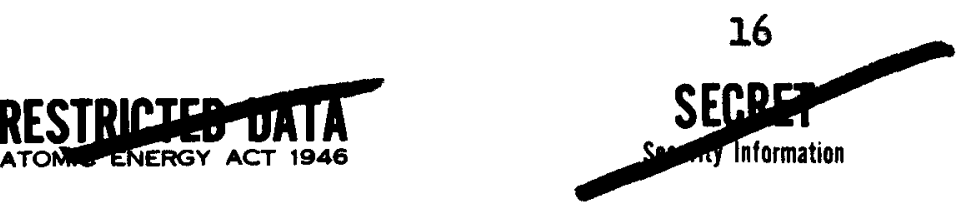




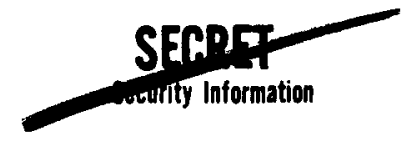

TABLE 2.1

Station Locations, Shot 1

\begin{tabular}{|c|c|c|c|c|c|c|c|c|c|c|c|c|c|}
\hline \multirow{2}{*}{$\begin{array}{l}\text { Tower } \\
\text { Station }\end{array}$} & \multirow{2}{*}{$\begin{array}{c}\text { Distance } \\
\text { from GZ } \\
(\mathrm{ft})\end{array}$} & \multirow{2}{*}{$\begin{array}{c}\operatorname{Recorder}^{(a)} \\
\text { Station }\end{array}$} & \multirow{2}{*}{$\begin{array}{l}\text { Recorder } \\
\text { Number }\end{array}$} & \multicolumn{4}{|c|}{ Calorimeters } & \multicolumn{3}{|c|}{ Foils } & \multicolumn{2}{|c|}{ Spheres } & \multirow{2}{*}{\begin{tabular}{|c}
$\begin{array}{c}\text { Radio- } \\
\text { meters(b) }\end{array}$ \\
$10 \mathrm{ft}$
\end{tabular}} \\
\hline & & & & Grade & $3 \mathrm{ft}$ & $10 \mathrm{ft}$ & $50 \mathrm{ft}$ & $1 \mathrm{ft}$ & $10 \mathrm{ft}$ & $50 \mathrm{ft}$ & Grade & $50 \mathrm{ft}$ & \\
\hline $\mathbf{F}-200$ & 0 & - & - & - & - & - & - & 1 & - & - & 1 & - & - \\
\hline F-202 & 500 & $F-220$ & $\begin{array}{l}435 \\
047 \\
005\end{array}$ & $\begin{array}{l}- \\
- \\
3\end{array}$ & $\begin{array}{l}- \\
-\end{array}$ & $\begin{array}{l}- \\
2 \\
-\end{array}$ & $\begin{array}{l}3 \\
- \\
-\end{array}$ & $\begin{array}{l}- \\
3 \\
-\end{array}$ & $\begin{array}{l}- \\
1 \\
-\end{array}$ & $\begin{array}{l}- \\
2 \\
-\end{array}$ & $\begin{array}{l}- \\
1 \\
-\end{array}$ & $\begin{array}{l}- \\
1 \\
-\end{array}$ & - \\
\hline F-204 & 1,000 & - & - & - & - & - & - & 1 & - & - & 1 & - & - \\
\hline F-206 & 1,500 & - & - & - & - & - & - & 1 & - & - & 1 & - & - \\
\hline$F-208$ & 2,000 & $F-221$ & $\begin{array}{l}436 \\
437 \\
438 \\
\end{array}$ & $\begin{array}{l}- \\
- \\
3\end{array}$ & $\begin{array}{l}- \\
- \\
-\end{array}$ & $\begin{array}{l}- \\
2 \\
-\end{array}$ & $\begin{array}{l}3 \\
- \\
- \\
\end{array}$ & $\begin{array}{l}- \\
3 \\
\end{array}$ & $\begin{array}{l}- \\
1 \\
-\end{array}$ & $\begin{array}{l}- \\
2 \\
-\end{array}$ & $\begin{array}{l}- \\
1 \\
-\end{array}$ & $\begin{array}{l}- \\
1 \\
-\end{array}$ & 10 \\
\hline $\mathrm{F}-210$ & 3,000 & - & - & - & - & - & - & 1 & - & - & 1 & - & - \\
\hline
\end{tabular}

(a) Recorder stations located opposite corresponding tower stations. Cable lengths from instrument to recorder vary from 50-150 ft.

(b) $D=$ disk radiometer.

TABLE 2.2

\section{Station Iocations, Shot 2}

\begin{tabular}{|c|c|c|c|c|c|c|c|c|c|c|c|c|c|}
\hline \multirow{2}{*}{$\begin{array}{l}\text { Tower } \\
\text { Station }\end{array}$} & \multirow{2}{*}{$\begin{array}{c}\text { Distance } \\
\text { from GZ } \\
\text { (ft) }\end{array}$} & \multirow{2}{*}{$\begin{array}{c}\text { Recorder }(\mathrm{a}) \\
\text { Station }\end{array}$} & \multirow{2}{*}{$\begin{array}{c}\text { Recorder } \\
\text { Number }\end{array}$} & \multicolumn{4}{|c|}{ Calorimeters } & \multicolumn{3}{|c|}{ Foils } & \multicolumn{2}{|c|}{ Spheres } & \multirow{2}{*}{\begin{tabular}{|c|}
$\begin{array}{c}\text { Radio } \\
\text { meters(b }\end{array}$ \\
$10 \mathrm{ft}$ \\
\end{tabular}} \\
\hline & & & & Grade & $3 \mathrm{ft}$ & $10 \mathrm{ft}$ & $50 \mathrm{ft}$ & $\mathbf{1} \mathbf{f t}$ & $10 \mathrm{ft}$ & $50 \mathrm{ft}$ & Grade & $50 \mathrm{ft}$ & \\
\hline $7-200$ & 0 & - & - & - & - & -1 & - & 1 & - & - & 1 & -1 & - \\
\hline $7-201$ & 750 & - & $=$ & - & - & - & - & 1 & - & - & 1 & - & - \\
\hline $7-202$ & 1,500 & $7-220$ & $\begin{array}{l}438 \\
437 \\
436 \\
\end{array}$ & $\begin{array}{l}- \\
- \\
-\end{array}$ & $\begin{array}{l}- \\
- \\
-\end{array}$ & $\begin{array}{l}- \\
- \\
4\end{array}$ & $\begin{array}{l}- \\
- \\
-\end{array}$ & $\begin{array}{l}1 \\
- \\
- \\
\end{array}$ & $\begin{array}{l}- \\
- \\
-\end{array}$ & $\begin{array}{l}- \\
- \\
-\end{array}$ & $\begin{array}{l}1 \\
- \\
-\end{array}$ & $\begin{array}{l}- \\
- \\
-\end{array}$ & $\begin{array}{c}1 W \\
- \\
- \\
\end{array}$ \\
\hline $7-204$ & 3,000 & $7-221$ & $\begin{array}{l}335 \\
005 \\
\end{array}$ & $\begin{array}{r}3 \\
- \\
\end{array}$ & - & $\begin{array}{l}1 \\
- \\
\end{array}$ & 2 & $\begin{array}{l}1 \\
- \\
\end{array}$ & - & - & $\begin{array}{r}1 \\
- \\
\end{array}$ & - & $\begin{array}{l}20 \\
- \\
\end{array}$ \\
\hline $7-206$ & 4,500 & - & - & - & - & - & - & 1 & - & - & 1 & - & - \\
\hline
\end{tabular}

(a) Recorder stations located opposite corresponding tower stations. Cable lengths from instrument to recorder vary from 50-150 ft.

(b)

$D=$ disk radiometer.

$\pi$ = fine-rire radiometer. 


\section{TABLE 2.3}

Station Locations, Shot 3

\begin{tabular}{|c|c|c|c|c|c|c|c|c|c|c|c|c|c|c|}
\hline \multirow{2}{*}{$\begin{array}{l}\text { Tower } \\
\text { Station }\end{array}$} & \multirow{2}{*}{$\begin{array}{l}\text { Distance } \\
\text { from } G Z \\
\text { (ft) }\end{array}$} & \multirow{2}{*}{$\begin{array}{c}\text { Recorder }(a) \\
\text { Station }\end{array}$} & \multirow{2}{*}{$\begin{array}{r}\text { Recorder } \\
\text { Number }\end{array}$} & \multicolumn{4}{|c|}{ Calorimeters } & \multicolumn{3}{|c|}{ Foils } & \multicolumn{2}{|c|}{ Spheres } & \multicolumn{2}{|c|}{$\begin{array}{c}\text { Radio- } \\
\text { meters(b) }\end{array}$} \\
\hline & & & & Grade & $3 \mathrm{ft}$ & $10 \mathrm{ft}$ & $50 \mathrm{ft}$ & $1 \mathrm{ft}$ & $10 \mathrm{ft}$ & $50 \mathrm{ft}$ & Grade & $50 \mathrm{ft}$ & $3 \mathrm{ft}$ & $10 \mathrm{ft}$ \\
\hline $7-200$ & 0 & - & - & - & - & - & - & 1 & - & - & - & - & - & - \\
\hline $7-202$ & 1,500 & $7-220$ & $\begin{array}{l}436 \\
438\end{array}$ & - & - & $\begin{array}{l}1 \\
-\end{array}$ & - & 1 & - & - & 1 & - & $\begin{array}{l}2 D \\
1 W \\
1 W\end{array}$ & - \\
\hline $7-204$ & 3,000 & $7-221$ & & $\begin{array}{l}3 \\
- \\
\end{array}$ & - & $\begin{array}{l}2 \\
- \\
\end{array}$ & $\overline{3}$ & - & $\overline{1}$ & $\overline{2}$ & $\overline{1}$ & - & $\begin{array}{l}- \\
-\end{array}$ & $\begin{array}{l}1 D \\
-\end{array}$ \\
\hline $7-206$ & 4,500 & - & - & - & - & - & - & 1 & - & - & 1 & - & - & - \\
\hline $7-208$ & 6.000 & $7-234$ & 865 & 2 & - & 1 & 2 & 3 & 1 & 2 & 1 & 1 & - & - \\
\hline $7-210$ & 9,000 & $7-222$ & 047 & $=$ & - & 6 & - & 1 & - & - & 1 & - & - & - \\
\hline $\begin{array}{l}\text { USFS } \\
\text { USFS } \\
\text { USFS } \\
\text { USFS } \\
\text { USFS } \\
\text { USFS }\end{array}$ & $\begin{array}{l}11,000 \\
12,000 \\
13,000 \\
16,000 \\
18,000 \\
20,000\end{array}$ & $\begin{array}{l}- \\
= \\
= \\
-\end{array}$ & $\begin{array}{c}- \\
- \\
- \\
961\end{array}$ & $\begin{array}{l}- \\
\overline{-} \\
\overline{-}\end{array}$ & $\begin{array}{l}- \\
\overline{-} \\
\overline{3} \\
-\end{array}$ & $\begin{array}{l}- \\
\bar{z} \\
\bar{z} \\
\overline{-}\end{array}$ & $\begin{array}{l}- \\
5 \\
5\end{array}$ & $\begin{array}{l}1 \\
1 \\
1 \\
1 \\
3 \\
1\end{array}$ & $\begin{array}{l}- \\
\bar{z} \\
\bar{z}\end{array}$ & $\begin{array}{l}- \\
- \\
5\end{array}$ & $\begin{array}{l}- \\
i \\
1 \\
1\end{array}$ & $\begin{array}{l}- \\
- \\
-\end{array}$ & $\begin{array}{l}- \\
\overline{-} \\
\overline{-}\end{array}$ & $\begin{array}{l}- \\
\overline{-} \\
-\end{array}$ \\
\hline
\end{tabular}

(a) Recorder stations located opposite corresponding tower stations. Cable lengths from instrument to recorder vary from 50-150 ft.

(b)

$D=$ disk radiometer. $W=$ fine-wire radiometer .

TABLE 2.4

Station Locations, Shot 4

\begin{tabular}{|c|c|c|c|c|c|c|c|c|c|c|c|c|c|c|}
\hline \multirow{2}{*}{$\begin{array}{l}\text { Tower } \\
\text { Station }\end{array}$} & \multirow{2}{*}{$\begin{array}{c}\text { Distance } \\
\text { from } G Z \\
\text { (ft) }\end{array}$} & \multirow{2}{*}{$\begin{array}{c}\text { Recorder(a) } \\
\text { Station }\end{array}$} & \multirow{2}{*}{$\begin{array}{l}\text { Recorder } \\
\text { Number }\end{array}$} & \multicolumn{4}{|c|}{ Calorimeters } & \multicolumn{3}{|c|}{ Foils } & \multicolumn{2}{|c|}{ Spheres } & \multicolumn{2}{|c|}{$\begin{array}{c}\text { Radio- } \\
\text { meters(b) }\end{array}$} \\
\hline & & & & Grade & $3 \mathrm{ft}$ & $10 \mathrm{ft}$ & $50 \mathrm{ft}$ & $1 \mathrm{ft}$ & $10 \mathrm{ft}$ & $50 \mathrm{ft}$ & Grade & $50 \mathrm{ft}$ & $3 \mathrm{ft}$ & $10 \mathrm{ft}$ \\
\hline $7-200$ & 0 & - & - & - & - & - & - & 2 & - & - & - & - & - & - \\
\hline $7-202$ & 1,500 & $7-220$ & $\begin{array}{l}436 \\
438\end{array}$ & - & $\begin{array}{l}- \\
-\end{array}$ & $\begin{array}{l}1 \\
-\end{array}$ & $\begin{array}{l}- \\
-\end{array}$ & $\begin{array}{l}2 \\
-\end{array}$ & - & - & - & - & $\begin{array}{l}2 p \\
1 w \\
2 w\end{array}$ & $\begin{array}{l}- \\
-\end{array}$ \\
\hline $7-204$ & 3,000 & $7-221$ & $\begin{array}{l}435 \\
437\end{array}$ & $\begin{array}{l}3 \\
-\end{array}$ & - & $\begin{array}{l}2 \\
-\end{array}$ & $\overline{3}$ & $\begin{array}{l}1 \\
-\end{array}$ & - & - & $\begin{array}{l}2 \\
-\end{array}$ & 2 & $\begin{array}{l}- \\
-\end{array}$ & 10 \\
\hline $7-206$ & 4,500 & - & - & - & - & - & - & 1 & - & - & 1 & - & - & - \\
\hline $7-208$ & 6,000 & $7-234$ & 865 & 2 & - & 1 & 2 & 1 & - & - & 1 & 2 & - & - \\
\hline $7-210$ & 9,000 & $7-222$ & 047 & - & - & 6 & - & 1 & - & - & 1 & - & - & - \\
\hline $\begin{array}{l}\text { USFS } \\
\text { USFS } \\
\text { USFS } \\
\text { USFS } \\
\text { USFS } \\
\text { USFS }\end{array}$ & $\begin{array}{l}11,000 \\
12,000 \\
13,000 \\
14,500 \\
16,000 \\
18,000\end{array}$ & $\begin{array}{l}= \\
z \\
z \\
-\end{array}$ & $\begin{array}{c}\overline{-} \\
\overline{-} \\
\overline{-} \\
961\end{array}$ & $\begin{array}{l}\bar{z} \\
\overline{-} \\
\overline{-} \\
\overline{-}\end{array}$ & $\begin{array}{l}\overline{-} \\
\overline{-} \\
\overline{3}\end{array}$ & $\begin{array}{l}\overline{-} \\
\overline{-} \\
\overline{-}\end{array}$ & $\begin{array}{l}\bar{z} \\
\overline{-} \\
\overline{-}\end{array}$ & $\begin{array}{l}1 \\
1 \\
1 \\
1 \\
1 \\
2\end{array}$ & $\begin{array}{l}\overline{-} \\
\overline{-} \\
\overline{-} \\
\overline{-}\end{array}$ & $\begin{array}{l}\bar{z} \\
\bar{z} \\
\overline{-}\end{array}$ & $\begin{array}{l}1 \\
1 \\
1 \\
- \\
1 \\
1\end{array}$ & $\begin{array}{l}5 \\
5 \\
5\end{array}$ & $\begin{array}{l}- \\
- \\
- \\
\overline{2 D}\end{array}$ & $\begin{array}{l}\overline{-} \\
\overline{-} \\
\overline{-}\end{array}$ \\
\hline
\end{tabular}

(a) Recorder stations located opposite corresponding tower stations. Cable lengths from instrument to recorder vary from 50-150 ft.

(b) $D=$ disk radiometer. $W=$ fine-wire radiometer. 


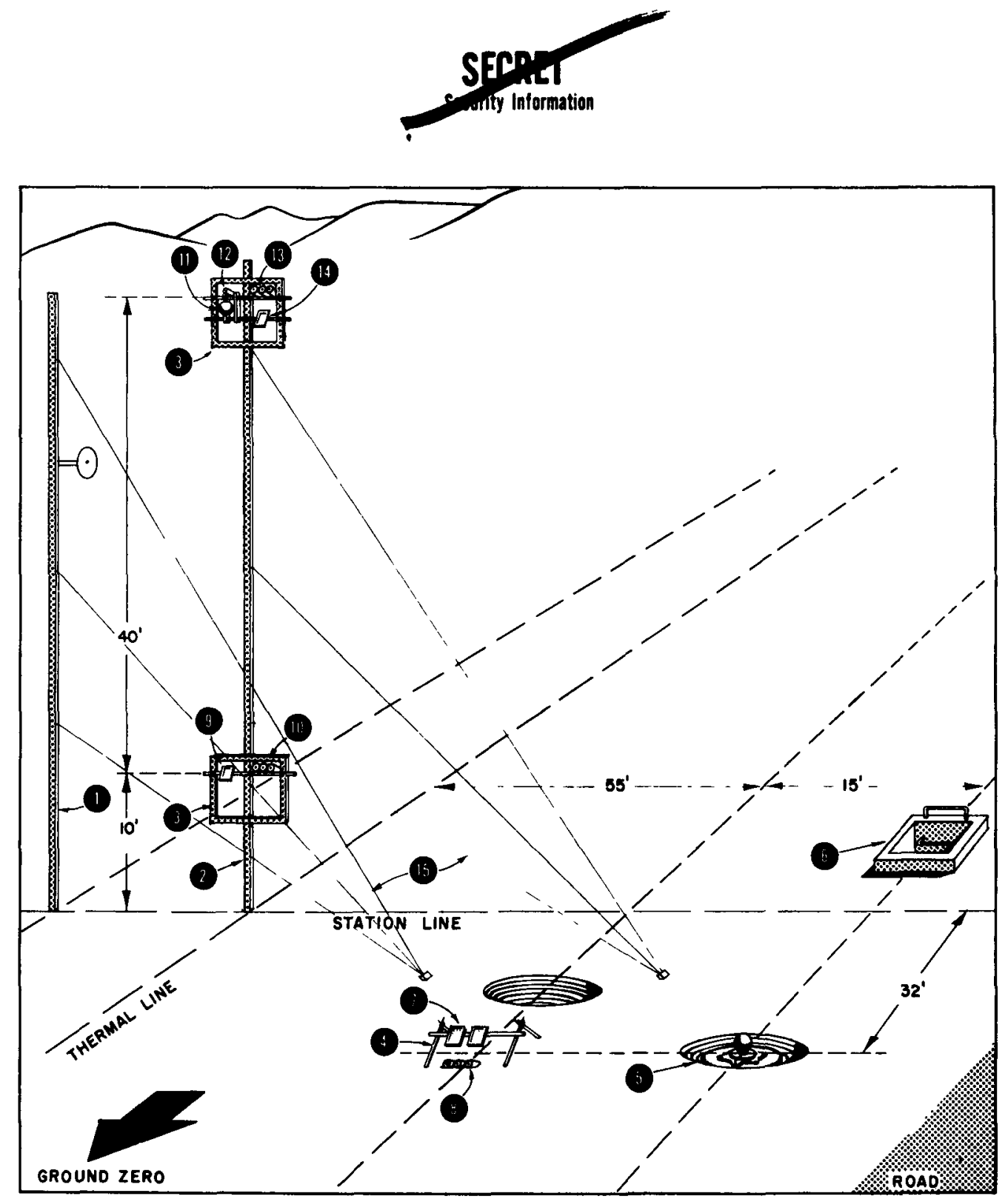

1. Blast Tower

2. Thermal Tower

3. Tower Instrument Support Frames

4. Surface Instrument Support Tubelox Frame

5. Sphere Calorimeter (At Grade)

6. Instrument Shelter

7. Passive Recelvers (1-ft Blev)
8. Calorimeters or Radiometers (At Grade)

9. Passive Receiver (10-ft Blev)

10. Calorimeters or Radiometers (10-ft Elet)

11. Sphere Calorimeter (50-ft Eler)

12. Photronic Cell (50-ft 표ev)

Fig. 2.I Isometric Draring of a Typical Station

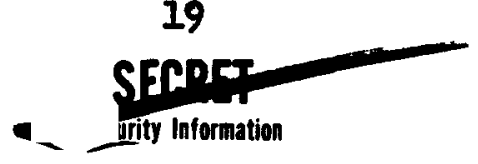

13. Calorimeters or Radiometers (50-ft Elev)

14. Passive Receiver (50-ft Elev)

15. Guy Wires (Laft, Front Only Shown) 

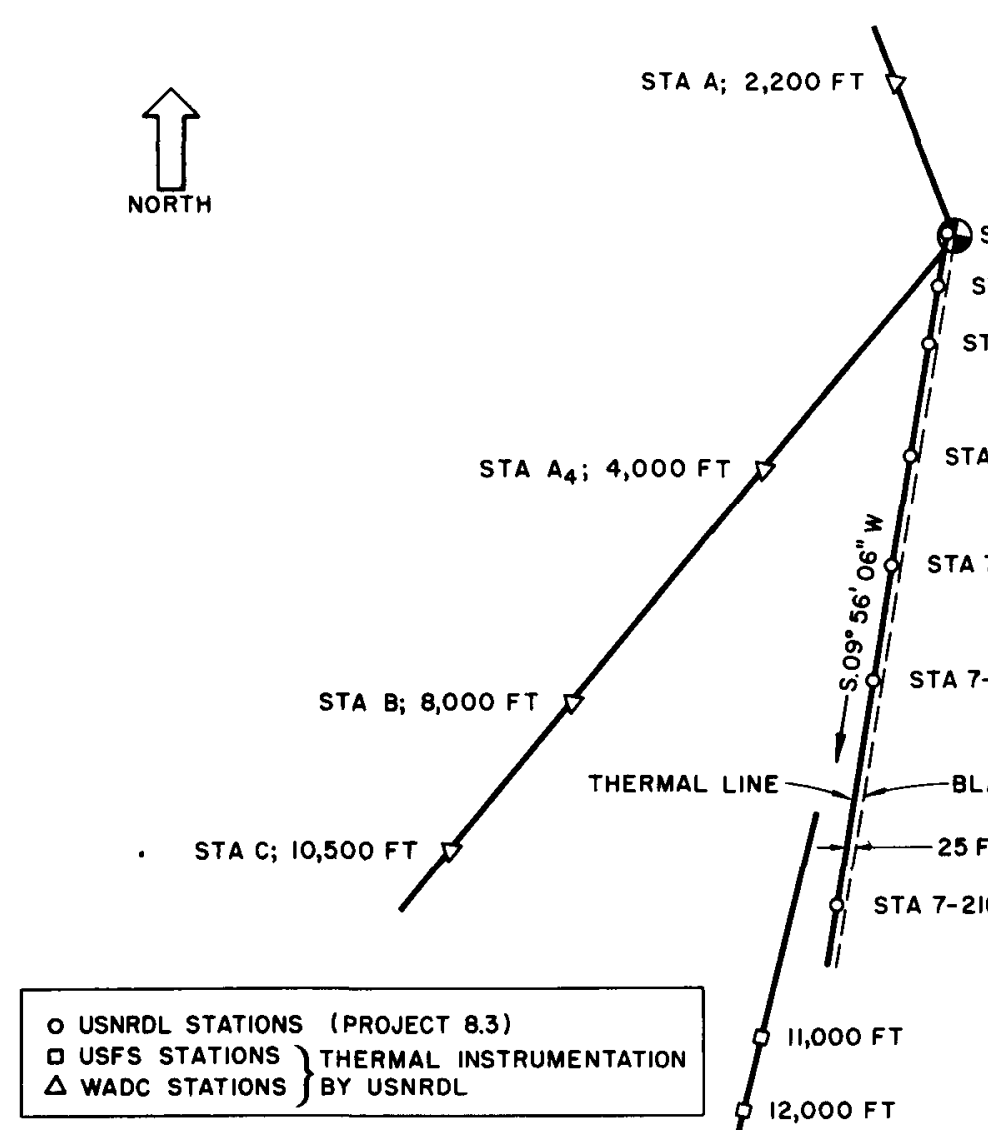

STA 7-200; GROUND ZERO

STA 7-20I; 750 FT

STA 7-202; 1,500 FT
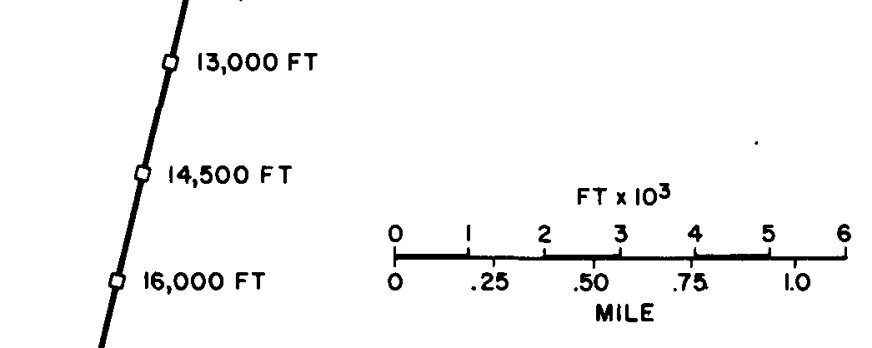

Fig. 2.2 Schematic Station Layout, T-7 Area 


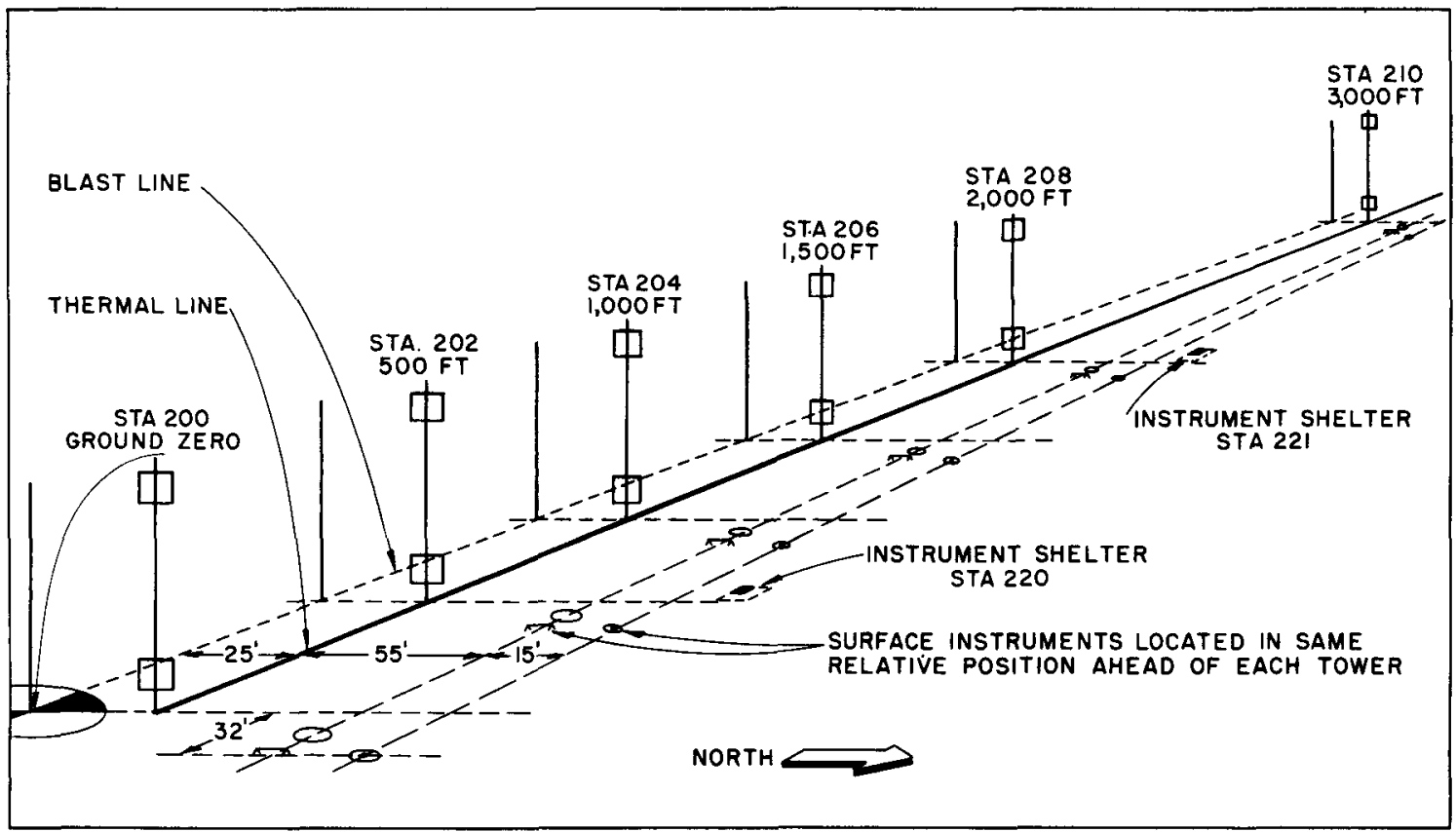

Fig. 2.3 Schematic Station Iayout, F Area

\subsection{DISK CALORTMETERS}

\subsubsection{Description}

Although the USNRDL field calorimeter was modified slightly prior to Operation TUMLER-SNAPPER, the basic design of the instrument did not change (Fig. 2.4). A disk-shaped energy receiver cut from copper and blackened on one face with electrolytically-deposited platimum and finish coated with camphor black, is exposed to thermal radiation through an appropriate filter. The receiving disks, $3 / 8$ in. in diameter, vary in thickness from 0.020 in. to 0.125 in., the thicknesses being selected so that the temperature rise in each disk would never be appreciably greater than $150^{\circ} \mathrm{C}$ in order that the heat losses from the disk would not be excessive.

Except in the case of the thickest disk, a thermocouple consisting of 5-mil copper and constantan wire is soldered to the center of the unblackened face of the disk. The other end of the thermoconple wire is fastened to the reference junction, comprised of massive copper blocks housed in the calorimeter case. The electrical signal generated by the thermocouple is fed into one galvanometer of a 12-channel Heilend oscillographic recorder.

Each receiving disk is afficiently thick to give a long time constant with respect to total energy measurements, that is, the 21 
the periphery of the disk.*

The thicknesses of all the receivers used, together with an indication of the energies for which these thicknesses were selected, are shown in Table 2.5. In this table, column 3 gives the temperature in degrees centigrade above the ambient temperature, which the receiver will attain when exposed to the energy listed in column 2. Colunn 4 gives the roltage generated at the thermocouple and column 5 gives the roltage which the galvanometer records to produce the deflection in column 6. The difference in the two voltages listed is due to the necessity of introducing a series resistance into the thermocouple circuits in order to properly damp the galvanometer.

TABLE 2.5

Gelvanometer Deflections for Various Energies and Disk Thicknesses

\begin{tabular}{|l|c|c|c|c|c|}
\hline \hline $\begin{array}{c}\text { Thickness } \\
\text { (in.) }\end{array}$ & $\begin{array}{c}\text { Energy } \\
\text { (cal/sq cm) }\end{array}$ & $\begin{array}{c}\text { Temperature } \\
\left.\text { ( }{ }^{\circ} \mathrm{C}\right)\end{array}$ & $\begin{array}{c}\text { Thermocouple } \\
\text { Signal } \\
\text { (mv) }\end{array}$ & $\begin{array}{c}\text { Recorded } \\
\text { Signal } \\
\text { (mv) }\end{array}$ & $\begin{array}{c}\text { Deflection } \\
\text { (cm) }\end{array}$ \\
\hline 0.125 & 40 & 150 & 6.8 & 3.2 & 4.3 \\
0.0625 & 20 & 150 & 6.8 & 3.2 & 4.3 \\
0.0312 & 10 & 150 & 6.8 & 3.2 & 4.3 \\
0.025 & 5 & 95 & 4.2 & 2.0 & 2.7 \\
0.020 & 3 & 70 & 3.2 & 1.5 & 2.0 \\
\hline
\end{tabular}

For the measurement of total energy the receiving disks were mounted behind quartz filters which transmit in the region between approximately $2200 \AA$ and $4.5 \mu$. A rough spectral breakdown was obtained by mounting receiving disks in back of Corning glass filter Nos. 0-52, 3-69, 2-58, and 7-56. These filters transmit, respectively, from 3600\&, 5200\&, $6400 \AA$, and $9500 \AA$ through $2.5 \mu$. Transmission curves for all the filters used are shows in Figs. 2.5 and 2.6. Diaphragms of various sizes were mounted (FIg. 2.4) on the aperture of some of the calorimeters so that the effect of the field of view on the energy received could be determined.

\subsubsection{Use as an Intensity Derice}

As mentioned above, the energy-rs-time traces recorded by the calorimeter circuits may be differentiated to give intensity-rs-time curves. This differentiation may be accomplished approximately by reading for a short time interval, $\Delta t$, the energy, $\Delta q$, recorded curing that interval and plotting the average intensity for the time interval, $\frac{\Delta q}{\Delta t}$, as a close approximation to the true intensity, $\frac{d g}{d t}$. Depending upon the infor-

* This was done at the suggestion of H. C. Hottel. 

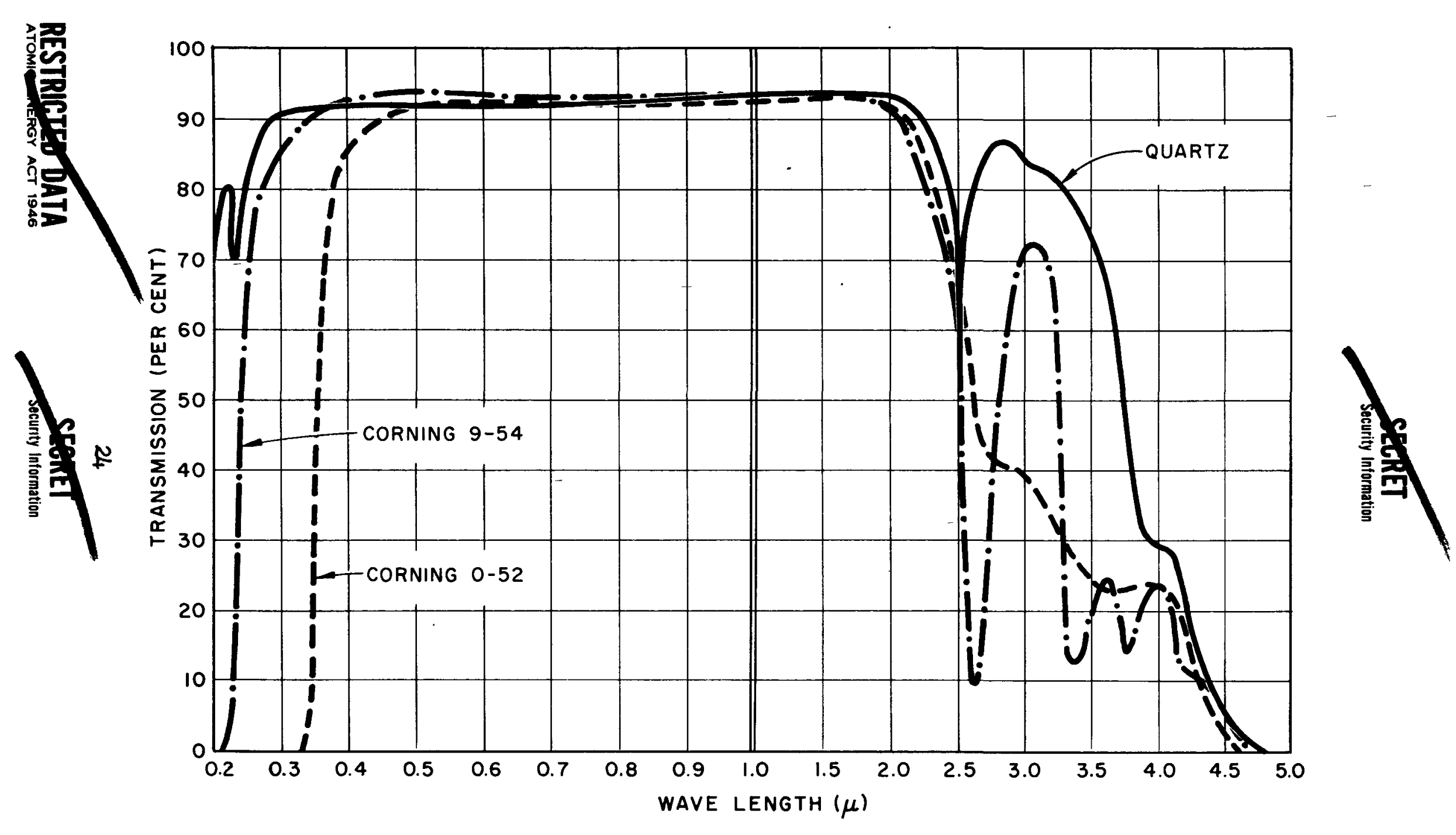

Fig. 2.5 Transmission Curves of Quartz and Corning Filters 9-54 and 0-52 

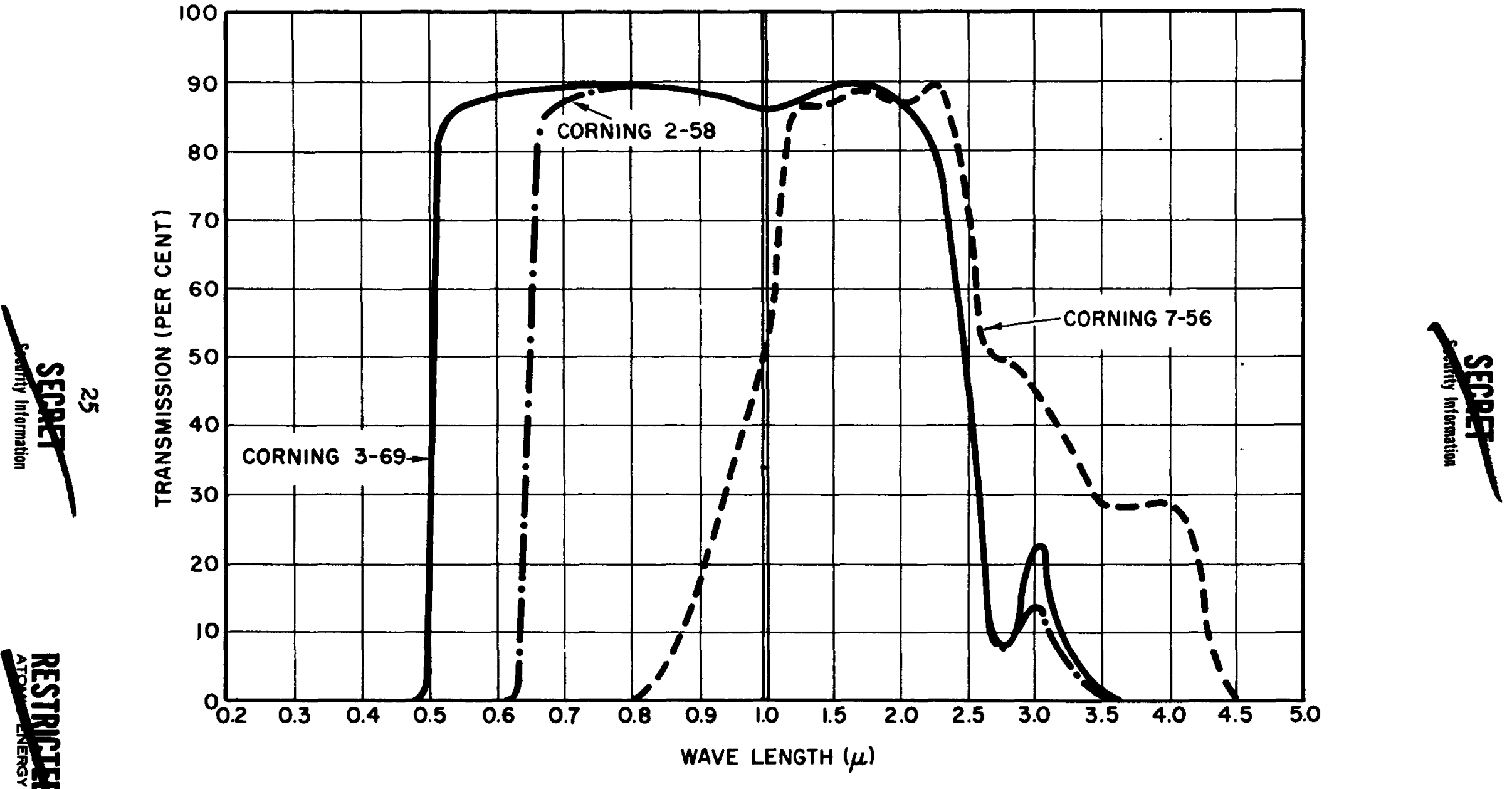

Fig. 2.6 Transmission Curves of Corning Filters 3-69, 2-58, and 7-56 


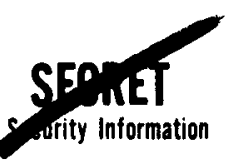

mation desired, the differentiation technique may be carried out in one of two ways. The difference between the two techniques depends upon the fact that the errors in reading the calorimeter traces are of two types: (1) a calibration or scale error, which is a constant percentage regardless of the magnitude of the deflection, and (2) the reading error, which is constant in value and thus varies percentagemise with the magnitude of the deflection.

The difference in the two techniques may be illustrated by taking as a typical case a trace with a total deflection of $3 \mathrm{~cm}$, which, for weapons of a magnitude used in this operation, would have at peak intensity a peak deflection rate of about $6 \mathrm{~cm} / \mathrm{sec}$, falling off at 2 sec to about 2.5 per cent of that value. Using the four-fold magnification In a Universal Telereader, Type 17A, the error in reading a good Heiland galvanometer trace is not greater than $\pm 0.003 \mathrm{~cm}$. The reading error for the total energy measurements then is $3 \pm 0.003 \mathrm{~cm}$, or 0.1 per cent, a negligible value.

However, as a time resolution of $20 \mathrm{msec}$ is desired, the Intensity curve must be based upon the deflection of the galvanometer during a 20-msec interval. At peak intensity, the error in this deflection would amount to $6 \mathrm{~cm} / \mathrm{sec} \times 0.02 \mathrm{sec}=0.12 \mathrm{~cm}$, and this valne would be known to $\pm 0.003 \mathrm{~cm}$, an error of \pm 2.5 per cent. However, at 2 sec the deflection chring the 20-msec interval would be only $0.003 \mathrm{~cm}$, and the uncertainty, then, would be equal in magnitude to the deflection itself.

If one restricts the need for a 20-msec time resolution to the interval around the peak intensity, where most damage is produced, it is possible by proper selection of $\Delta t$ to maintain a fixed percentage error in the intensity value. Thus, if time intervals are chosen so as to maintain the energy interval found at peak intensity, $0.12 \mathrm{~cm}$ in the example above, the uncertainty in the energy for the time interval will remain constant and thus the uncertainty in the intensity will remain constant. This procedure gives the average intensity fairly accurately for the time interval over wich the measurement is made.

In obtaining intensity-time curves, rectangles representing the time interval selected and the corresponding error in the intensity for each point may be plotted rather than the point itself. This procedure has the added advantage of having the long axis of the rectangle of uncertainty lie parallel to the curve in regions of slowly changing slope, thus simplifying the drawing of the curve.

\subsection{DISK RADIOMETER}

\subsubsection{Historical}

The use of the thick copper disk as a receiving element for measuring the intensity of the thermal radiation from a nuclear detonation

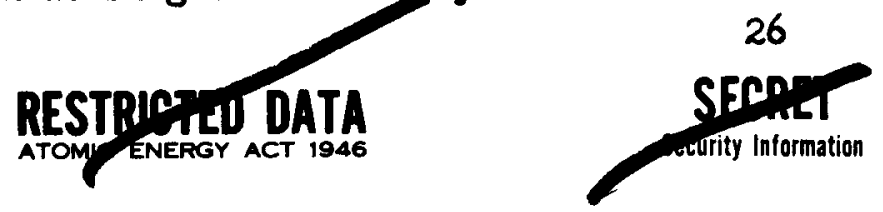




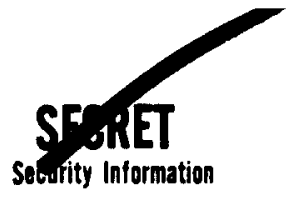

was a secondary consideration in the original design of a disk calorimeter. The concept and the validity of differentiating the total energy curve recorded by the calorimeter to obtain a rate curve originated during operation GREENHOUSE. However, the procedure is laborious and cannot very well be done in the field. An elaborate reading instrument is required in order to read the original traces with sufficient accuracy for the differentiation. The effect of electrical noise upon the record is disastrous when differentiation is attempted.

There has long been a need for a device which would record directly the intensity of the thermal pulse obtained in the field, and shortly after Operation BUSTER a limited amount of work was initiated in this direction both at USWRDL and at the Massachusetts Institute of Technology (MIT). The work was reviewed at the January, 1952, meeting of the AFSWP panel on thermal radiation and it was agreed that USRRDL would attempt to test a new type of radiometer during operation IULAIER-SNAPPER. At that time H. C. HotteI, of MIT, turned over to USNRDL a prototype of an instrument which was used during Operation TUMBLER-SNAPPER. Several similar instruments were built at USRRDL and also tested during these operations.

\subsubsection{Description of the Instrument}

The design proposed by H. C. Hottel was adopted because it was fairly. easy to construct and, once made, proved to be very rugged for field use. A cross section of the radiometer is given in Fig. 2.7. The receiving element is a thin disk of constantan foil which covers a small hole drilled in a massive block of copper. The foil is held in place by an annular ring secured to the block by aligning serews. A very thin copper wire is soldered to the center of the back surface of the foil to provide the thermo-electric hot junction. The junction of the constantan foll and the massive copper block constitutes the cold junction. The energy absorbed by the foll rapioly dissipates into the block, so there is a relatively small temperature increase in the foil and a negligible Fise in the temperature of the surface of the copper block. The central copper wire is fastened to a terminal in an insulated block at the back of the massive copper piece. A second terminal is made in the copper block and these two terminals are connected through appropriate resistances to the Heiland galvanometer. After the instrument is assembled, the front surface of the constantan foll is blackened with camphor smoke.

\subsubsection{Calibration of the Disk Radiometer}

According to H. C. Hottel, a theoretical calibration constant can be determined for these instruments by the use of the following equation for the steady state condition:

$$
\frac{\Delta T}{I}=\frac{r^{2}}{4 \bar{K}}
$$

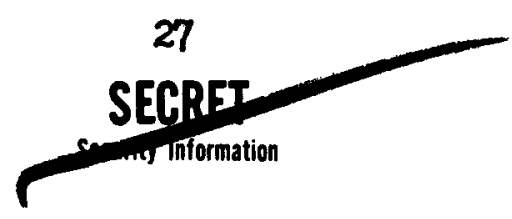




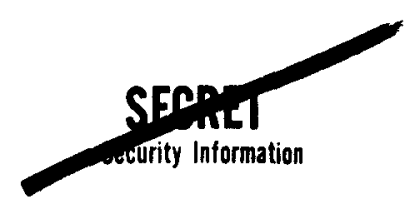

where $I=$ Intensity of the absorbed radiant energy,

$\Delta T=$ Temperature difference between the edge and the center of the foil,

$r=$ Radius of the circular foil as defined by the radius of the hole in the copper block,

$Y=$ Thickness of the foil, and

$\mathrm{K}=$ Thermal conductivity of the foil.

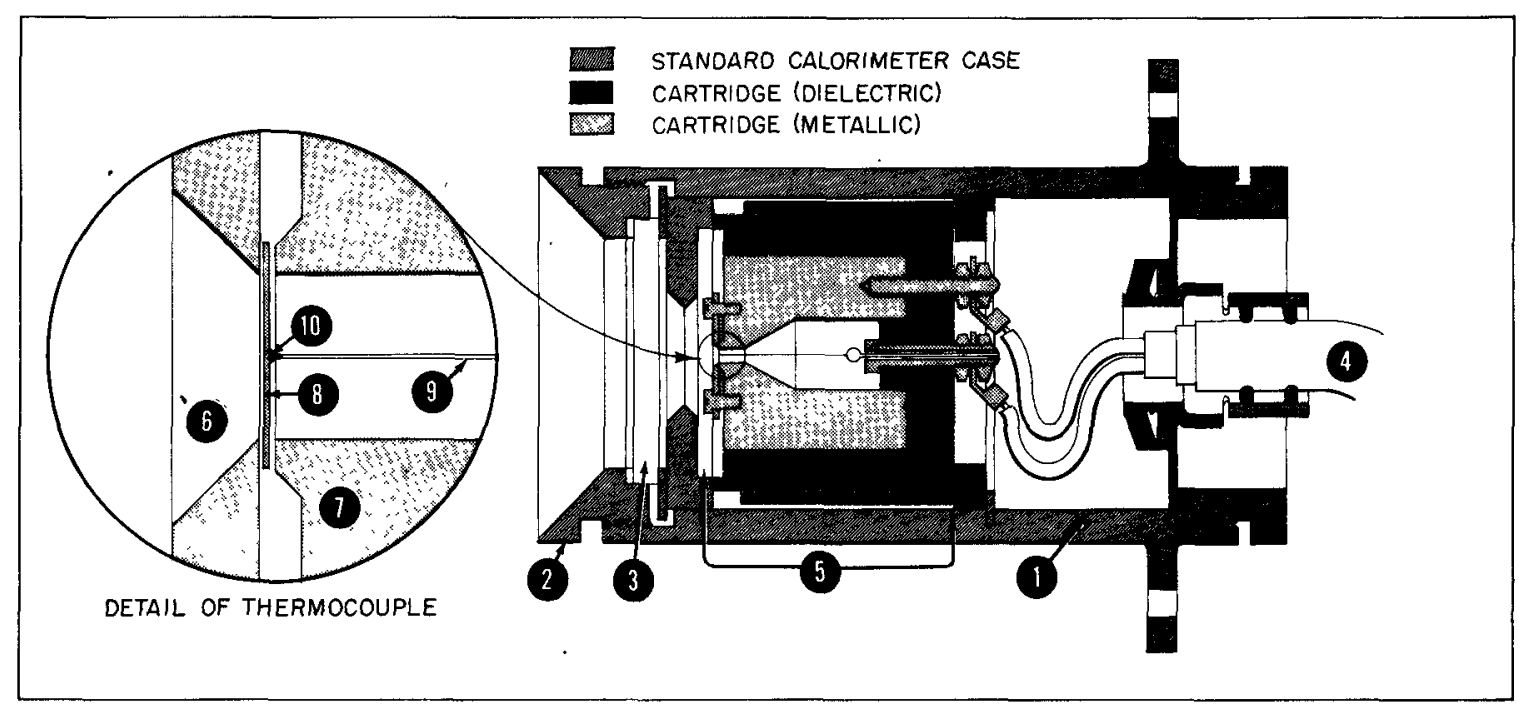

1. Std Calorimeter Case and Fittings (3-in. OD)

2. Std Aperture Ring ( 450 Halfangle Field)

3. Filter (Quartz or Corning 2-58)

4. DHFTA-9 No. 10 Cable to Recorder
5. MIT Foil Radioneter Cartridge

6. Secondary Aperture and Pressure Plate

7. Copper Reference Block

8. Constantan Foil

9. Copper Lead-in Wire

10. Lead-in Soldered to Foil

\section{Plg. 2.7 Cross Section of Disk Radiometer}

The calculated sensitivity for the instrument (MIT-3) given to USNRDL, is $\frac{\triangle I}{I}=5.80 \mathrm{C} / \mathrm{cal} / \mathrm{sq} \mathrm{cm} / \mathrm{sec}$. The sensitivity as determined experimentally at UIT was $2.90 \mathrm{C} / \mathrm{cal} / \mathrm{sq} \mathrm{cm} / \mathrm{sec}$. The front surface of the UIT-3 radiometer was blackened before use at USNRDL. Recalibration at that time gave a sensitivity value of $8.00 \mathrm{C} / \mathrm{cal} / \mathrm{sq} \mathrm{cm} / \mathrm{sec}$. The latter value has been used in the reduction of all field data.

An estimate of the time constants for the instruments can be determined from the equation, $\tau=\frac{r^{2} C_{p} \rho}{\delta_{K}}$, where $c_{p}$ and $\rho$ are the specific heat and density, respectively, of the receiving element (the other
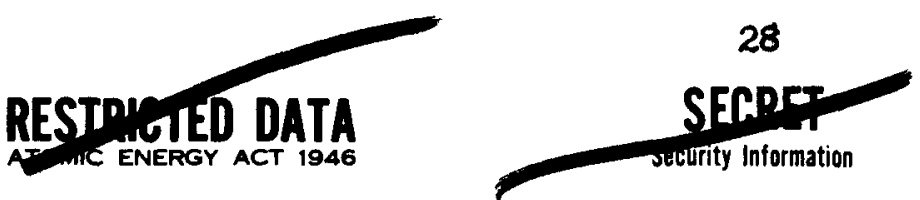


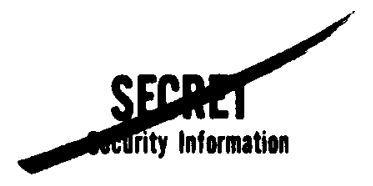

quantities have been previously defined). Values of the time constant for the UIT-3 radiometer are as follows: theoretical, 0.0034 sec; experimental MIT, $0.012 \mathrm{sec}$; and experimental USNRDL, $0.013 \mathrm{sec}$. It may be seen that the experimental time constant is well below the requirement of 20 msec.

\subsection{FINE-WIRE RADIOMETER}

\subsubsection{Description}

The fine-wire radiometer used in Project 8.3 was inspired by the thermocouple devices used in the air temperature measurements of Project 8.2. For the air temperature measurements the heated air was dram past a fine-wire silver-constantan thermocouple which was shielded from the thermal radiation. For the intensity measurements a similar finewire thermocouple is exposed to the fire ball and cooled by a high-velocity stream of air from a constant-temperature air supply.

The thermocouple was made of 2-mil constantan wire, half the length of which had been silver-plated, and was mounted adjacent to the end of a Pyrex tube in such a way that the silver-constantan junction was centered in the tube opening. The thermocouple reference junctions consisted of large brass blocks mounted inside a metal shield. Figure 2.8 shows a cross sectional view of the instrument. The output of the thermocouple is again recorded on a channel of the Heiland recorders used for the other Project 8.3 measurements. The entire recording circuit (except for a small portion of the thermocouple exposed to the thermal radiation) is electromagnetically shielded.

The cooling air was supplied b.y a 20-cu-ft compressed air tank buried in the ground behind the instruments. The air flow was controlled by means of a solenold operated through an Agastat relay circuit similar to those used for the Project 8.2 temperature measurements. By maintaining a high air flow past the wire, the net heating of the wire upon absorption of the thermal radiation may be kept to reasonable values, and the time constant of the system is considerably reduced.

\subsubsection{Theory}

For anj radiant flux incident a heat balance is established between the heating effect of the thermal radiation and the cooling of the air stream. The general expression for the heat balance is:

$$
a I D L=C_{p} \pi \frac{D^{2}}{4} L \frac{d T}{d t}+h \pi D L\left(T-T_{a}\right)
$$

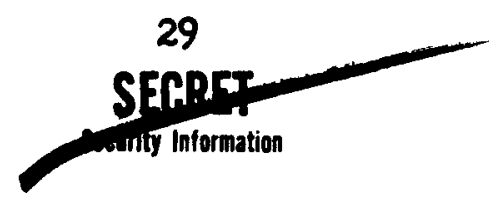



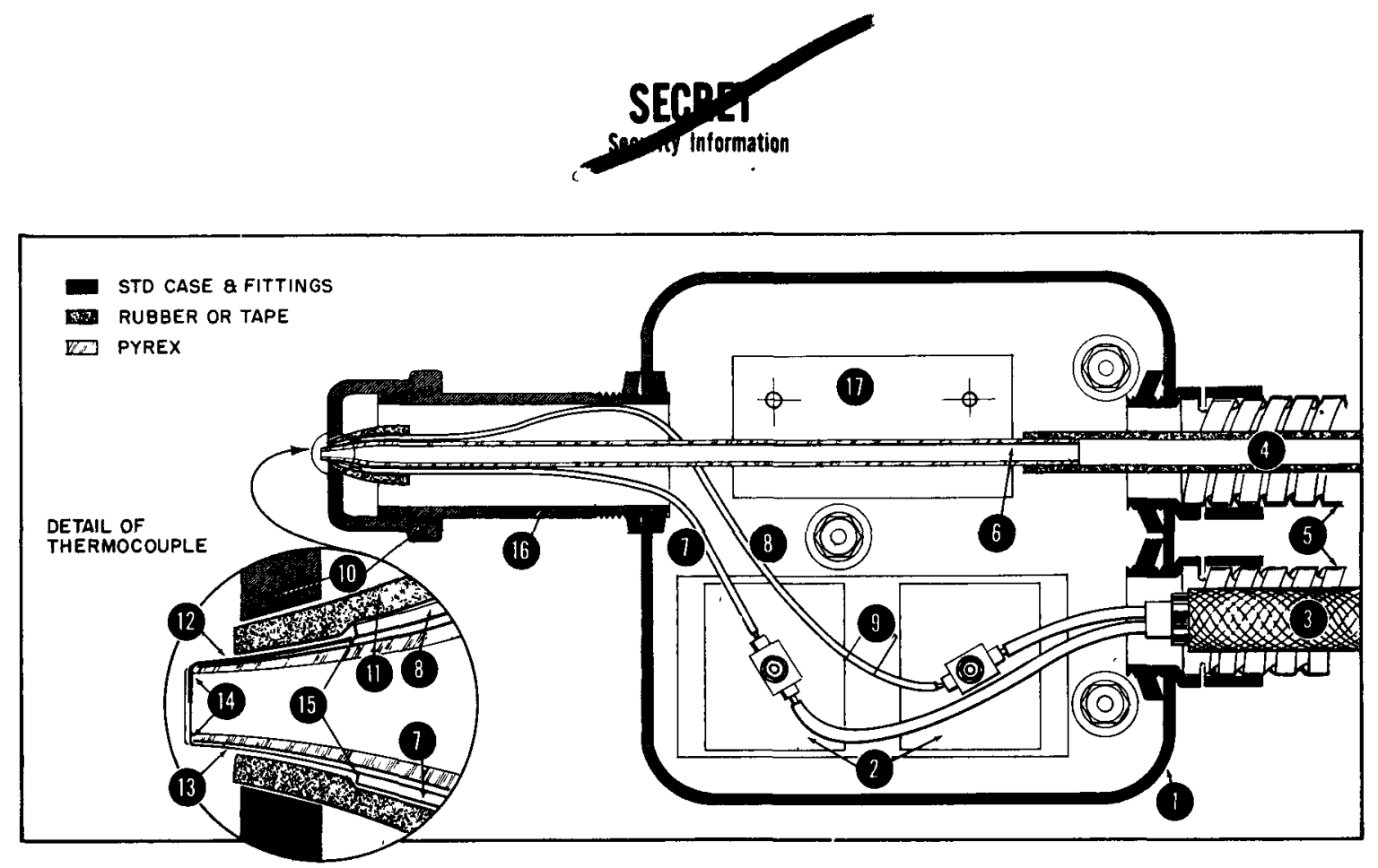

1. 4-11/16 in. Square Hectrical Junction Box

2. Brass Reference Blocks

3. DHFTA-9 No. 10 Cable to Recorder

4. Air Supply (Bubber Hose, 1/4-in. ID)

5. 3/4-in. Flexible Metallic Conduit

6. Pyrex Nozzle Tube

7. Thermocouple Iead-in Wire (Constantan)

8. Thermocouple Lead-in Wire (Copper)
9. Thermocouple Identification Tag

10. Nozzle Guard (3/4-in. IPS Pipe Cap)

11. Dielectric Tape

12. Silver-plated Constantan Wire

13. 0.002-in. D Constantan Wire

14. Nozzle Notched to Receive Wire

15. Thermocouple Wires Soldered to Lead-in

16. 3/4-in. IPS Nipple

17. Nozzle Nounting Block

Fig. 2.8 Cross Section of Fine-wire Radiometer

where $a=$ Absorptivity of the wire,

$I$ = Irradiation (cal $/ \mathrm{sq} \mathrm{cm} / \mathrm{sec}$ ),

$D=$ Diameter of wire $(\mathrm{cm})$,

$\mathrm{L}=$ Iength of wire $(\mathrm{cm})$,

$c_{p}=$ Specific heat of wire $\left(\mathrm{cal} / g /{ }^{\circ}\right)$,

$\rho=$ Density of wire $(\mathrm{g} / \mathrm{cu} \mathrm{cm})$,

$T=$ Temperature of wire $\left({ }^{\circ} \mathrm{C}\right)$,

$t=$ Time (sec),

$\mathrm{h}=$ Forced convection heat transfer coefficient for the wire in perpendicular air flow ( $\left.\mathrm{cal} / \mathrm{sq} \mathrm{cm} /{ }^{\circ} \mathrm{C} / \mathrm{sec}\right)$, and

$\mathrm{T}_{\mathrm{a}}=$ Air temperature $\left({ }^{\circ} \mathrm{C}\right)$.

From Equation 2.1 it may be seen that the temperature rise of the wire may be expressed by: 


$$
T-T_{a}=\frac{a I\left(1-a-\frac{4 h}{C_{p} D D}\right)}{\pi h}
$$

ment is given by:

Under equilibrium condition the sensitivity of the instra-

$$
\frac{T-T_{Q}}{I}=\frac{a}{\pi h}
$$

The time constant, $\tau$, of the wire can be obtained from the exponent of Equation 2.2:

$$
\tau=\frac{C_{p} \rho D}{4 h} \text { sec }
$$

An expression for the heat transfer coefficient, $h$, can be obtained from MeAdams: 10

$$
\frac{h D}{k}=0.32+0.43\left(\frac{D V y}{\mu} 0.52\right. \text {, }
$$

where $\frac{h D}{k}=$ Nusselt's mumber (consistent units), and

$$
\frac{D V Y}{\mu}=\text { Reynold's mumber (consistent units). }
$$

For air at $20^{\circ} \mathrm{C}$ at a velocity of $450 \mathrm{ft} / \mathrm{sec}$ and for a

2.4-mil (0.006-cm) constantan wire, Equation 2.5 reduces to:

$$
\mathrm{h}=0.14 \mathrm{cal} / \mathrm{sq} \mathrm{cm} /{ }^{\circ} \mathrm{C} / \mathrm{sec}
$$

Substituting this value for $h$ in Fquation 2.4 , and assuming $\frac{C_{p} \rho D}{4}=0.0014$ for the constantan wire,

$$
\tau=0.010 \mathrm{sec}=10 \mathrm{msec}
$$

For an air velocity of $450 \mathrm{ft} / \mathrm{sec}$, and a wire absorptivity of 0.20 , the sensitivity of the instrument becomes:

$$
\frac{T-T_{a}}{I}=0.46^{\circ} \mathrm{C} / \mathrm{cal} / \mathrm{sq} \mathrm{am} / \mathrm{sec}
$$

Since the thermocouple devices were developed for use in the atr temperature measurements of Projeet 8.2 and adapted at the last mimate for use as radiometers, no calibration other than the theoretical

31

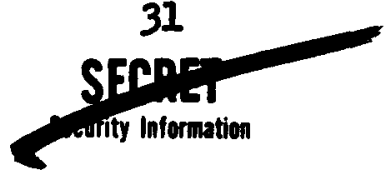


upon the foils, and since this effect wlll not be produced at intensities below a certain critical intensity, the foils measure effective, rather than the true, total energy. Where measurements were made with the foil panels at stations at which measurements were also made with other instruments, the measurements served as a check of the degree to which this effective energy approximates the true energy.

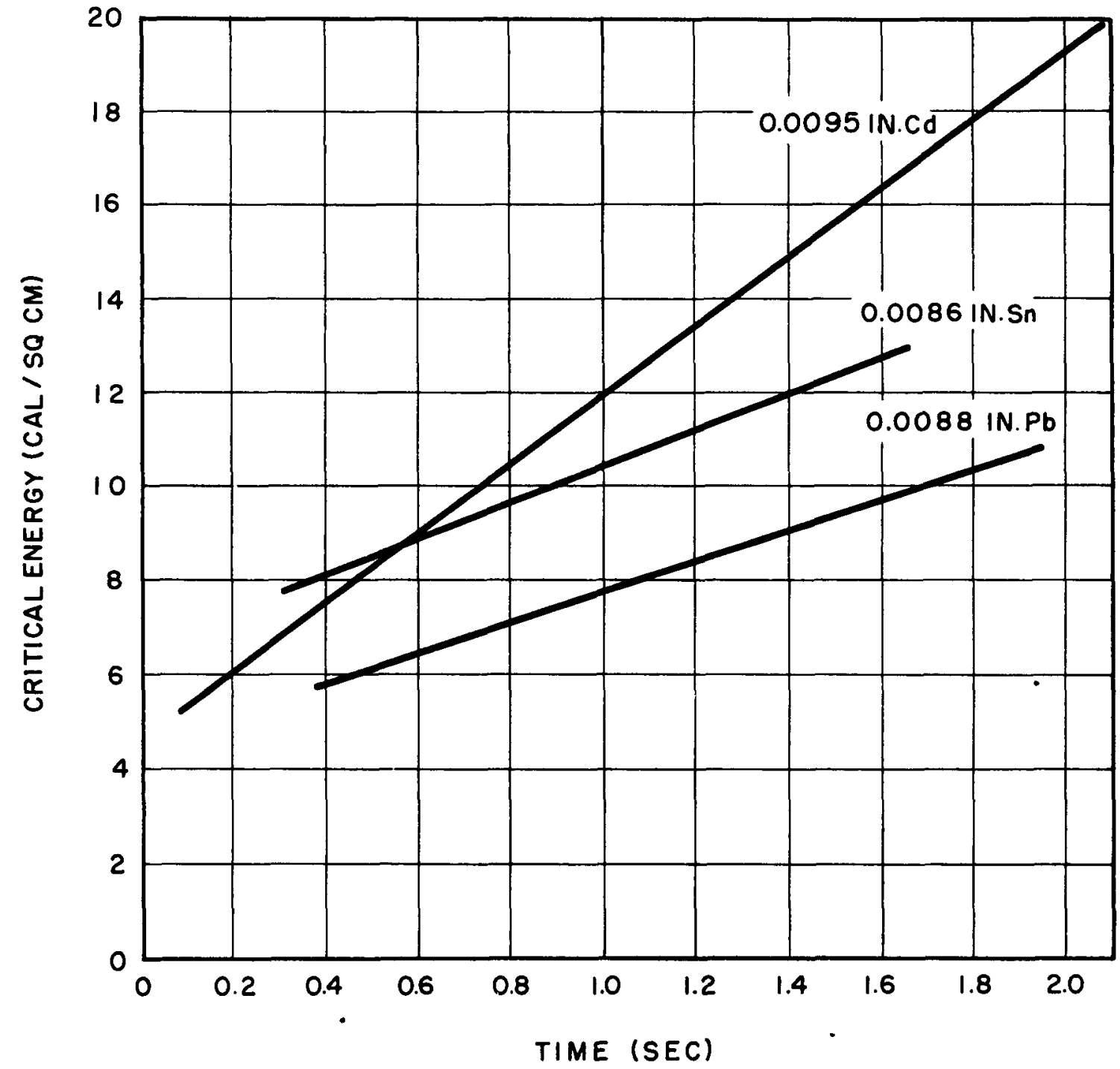

Fig. 2.9 Typical Calibration Curves for Passive Receivers

Since the shape of the thermal polse varies with the field of the weapon, and since the energy in a long, low-intensity pulse would not be effective in producing damage to the foils, it ras expected that the ratio 


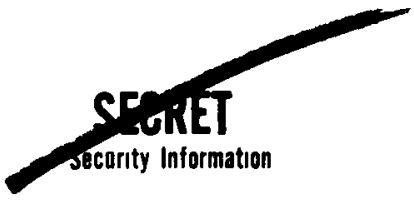

of effective energy to true energy would decrease with increasing gield. Having established a ratio of effective to true energy for a particular weapon, the foil panels could then be used to provide an indication of a value of true thermal energy at stations at which no recording channels were available for obtaining the true value directly.

The total mumber of panels exposed during. the four shots was 60: 16 on the first shot, 5 on the second, 24 on the thite and 15 on the last. For each panel position a value of expected energy was calculated and an energy range for each panel was found by multiplying this expected value by 0.3 and 1.3 for the $0.5-$ to $30-\mathrm{cal} / \mathrm{sq} \mathrm{cm}$ range, 0.25 and 1.5 for the 30 - to $70-\mathrm{cal} / \mathrm{sq} \mathrm{cm}$ range, and 0.21 and 1.7 for the range extending upwards from $70 \mathrm{cal} / \mathrm{sq} \mathrm{cm}$. For each of these ranges a geometrical progression of eight steps of energy values was calculated between the limits of the range. Based upon the laboratory calibrations, corresponding thicknesses of the three metals were determined after making assumptions on field pulse time. Some simplification was accomplished by grouping almostequal thicknesses and similar panels.

It was found that all of the ranges fell nicely into 11 groups, thus reducing the complexity of fabrication by a large factor. The 60 panels used included 27 thicknesses of cadmium ranging from 0.8 to $62 \mathrm{mil}, 23$ thicknesses of tin from 0.6 to $43 \mathrm{mil}, 26$ thicknesses of lead from 0.8 to $55 \mathrm{mil}$, 19 thicknesses of silver from 1 to $125 \mathrm{mil}$, and 22 thicknesses of copper from 1.1 to $80 \mathrm{mil}$. With a few exceptions the geometry of the receivers was the same as that used in the previous operations: 13/16-in.-D disks with apertures which permitted tham to receive radiation on an area of 3/8-in. $D$ in the center. The folls were also exposed in two other types of geometry. Strips $13 / 16 \mathrm{in.} \mathrm{Iong} \mathrm{and} 1 / 8 \mathrm{in.}$ wide were used in the high energy. range as a third indicator. Disks $13 / 32$ in. in diameter, attached to the insulating washers by three tabs, $1 / 16$ in. wide and $3 / 16$ in. long, were incorporated into the lowest-energy panels, since they are more sensitive than the standard size disk.

\subsection{SPHERE CALORDMETERS}

The sphere calorimeter has been designed by NRI personnel and used by them during Operation BUSTER - JANGLE. A photograph of the instrument is shown in Fig. 2.10. Its principle of operation is based on the general gas law. The gas is air, enclosed (at constant volume) in a copper sphere. The air is heated when thermal radiation falls on the sphere. The resulting increase in pressure of the air moves a beryllium-copper diaphragm in the bottom of the sphere. The deflection of the diaphragm is measured by a dial indicator. The indicator is mounted below the diaphragm in such a manner that the contact point of the indicator rides on a button in the center of the diaphragm. The indicator is so constructed that it registers movements in a positive direction only. To prevent spurious readings me to diurnal fluctuations of temperature and pressure, a slow leak is
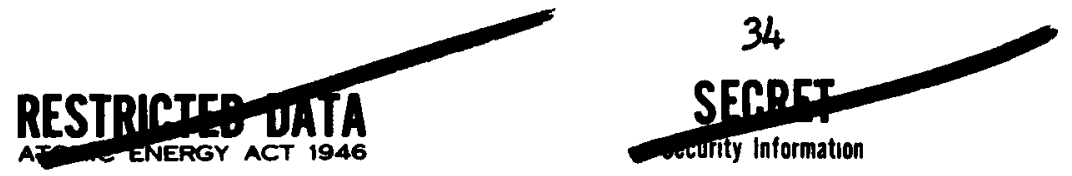
provided in both the sphere and the bottom cover.

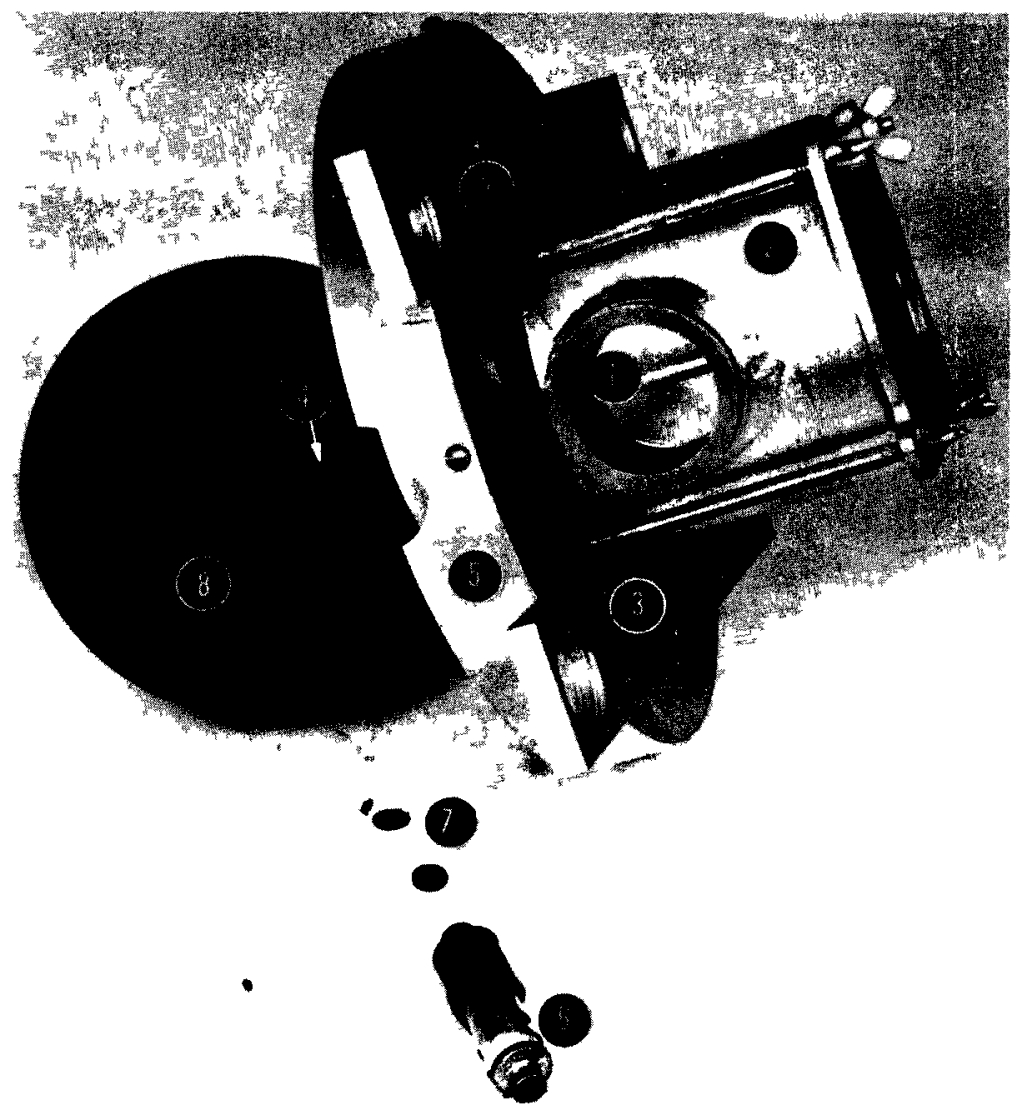

1. Dial Indicator

2. Diaphragm and Indicator Case

3. Base Bracket

4. Breather Connection Fitting
5. Guard Ring

6. Desiccator Plug

7. Breather Aperture Washer

8. Sphere

Fig. 2.10 Sphere Calorimeter

With considerable care and effort reasonable data were obtained during Operation BUSTER, but the Operation JANGLE results were not as satisfactory. The instruments were calibrated by KRL personnel and transferred to USNRDL personnel at the Nevada Proving Grounds during Operation TUMBLER. Since the instruments were still in the development stage, and since Project 8.3 personnel did not have time to familiarize themselves with the operation of the device, not too much hope was held for successfol performance during Operation TUMBLER-SNAPPER. However, it was expected that experience with the calorimeters during this field operation would promote successful use of these devices in future operations. 


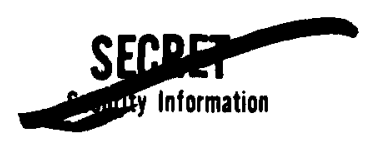

\subsection{CIRCUITS}

Tro types of electrical circuits were involved in this operation: the power and signal circuits on which all instruments were operated, and the recording eircuits through which the electrical impulses produced by the thermal radiation detection devices were recorded by the Heiland galvanometers. All power required to operate the instruments was provided by 24-v aircraft batteries located in the instrument shelters. All recorders were activated by the minus 5-sec EG\&G signals which actuated secondary relays used to close the power circuits. In the power circuits, Agastat time-delay relays were used to close the circuits, hold them closed for predetermined periods of time and then to open them. For recording of thermocouple outputs, a completely shielded circuit, properly grounded, was made up of two-conductor armored cable (the armor served as a shield) between the calorimeters and a closed junction box in the instrument shelter, and between the junction box and the Heiland recorders. The junction box was used to mount appropriate resistors, to obtain proper sensitivity and damping for the galvanometers, and as a convenient place for applying electrical calibration signals. As a check on the protection offered by the armored cable, several other types of cables were used at the 10-ft elevation at Station 7-202 shot were Romex, Romex in flexible metallic conduit, and twisted bell wire.

Since instrument shelters were provided at each station at which dynamic instrumentation for Project 8.3 was placed, no extremely long lengths of cable were used for the Project 8.3 instruments. The same recorders were used for this project as for Project 8.2 measurements. For the instruments mounted on the tower the armored cable was run down the inside of the tower post, thence into 2-ft trenches and into the instrument shelters. For the instruments mounted on the Tubelox racks, the cable was again run in trenches to the instrument shelters. A block diagram of a typical electrical circuit is shown in Fig. 2.11.

\subsection{MOUNTING}

For maximum ease and flexibility all instrument mounts were designed to fasten to 2-in. OD Tubelox pipe. All instrumentation on the towers was supported by horizontal Tubelox lengths attached by U-bolts to the $6-x$-ft mounting frames provided at the 10- and 50-ft elevations on the towers. Surface-mounted instruments were supported and anchored by a pair of 6-x 6-ft right-angle "A" frames set in the ground $3 \mathrm{ft}$ apart with their bases parallel to the blast line and their apices $2 \mathrm{ft}$ above grade. The instruments were mounted on stringers across the sloping front face of this framework. Standard 8-in.-D Tubelox base plates were attached by bayonet flttings to the four legs of the framework. The base of each frame was buried in the ground at distances $55 \mathrm{ft}$ to the left and $32 \mathrm{ft}$ forward (toward ground zero) of the corresponding thermal tower.

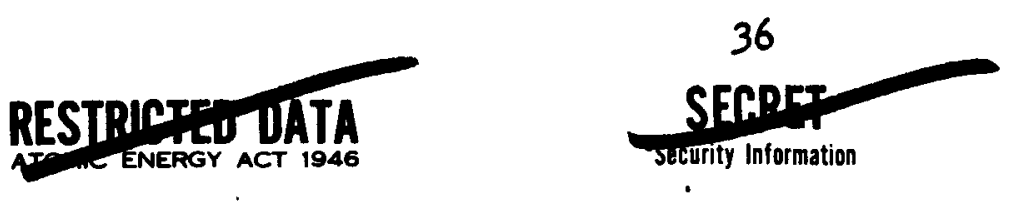




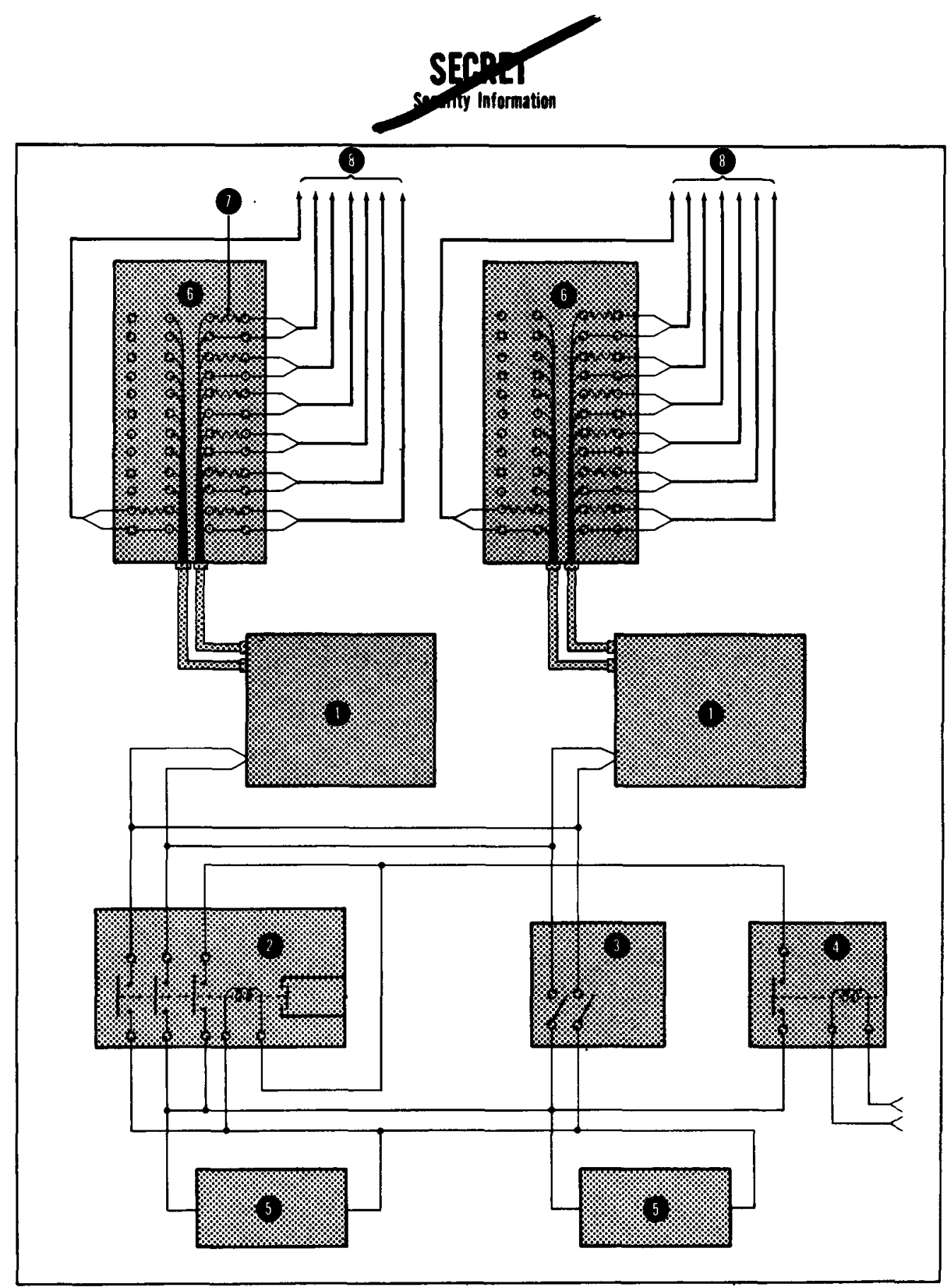

1. 12-channel 24-V Heiland Oscillograph Recorder

2. "Agastat" Time Delay Relay

3. Recorder Test Switch

4. "EGEG" Signal Relay
5. 24-r, 51-amp-hr Batteries

6. Recording Cireuit Junction Boxes

7. Impedance Matching Resistors

8. DHFTA-9 No. 10 Cables to Calorimeters

Fig. 2.17 Circuit Diagram of Iypical Instrument Station 


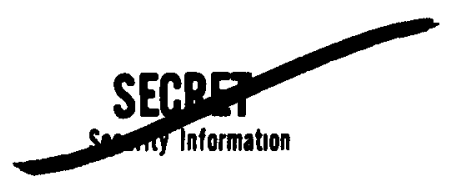

A view of a typical grade-level installation is given in F1g. 2.12. The mounting of the instruments at the 10- and 50-ft elevations on the tower is shown in Figs. 2.13 and 2.14, respectively. In over-all view of the complete installation is given in Fig. 2.15. In this figure the ground installation can be seen in the lower right hand corner.

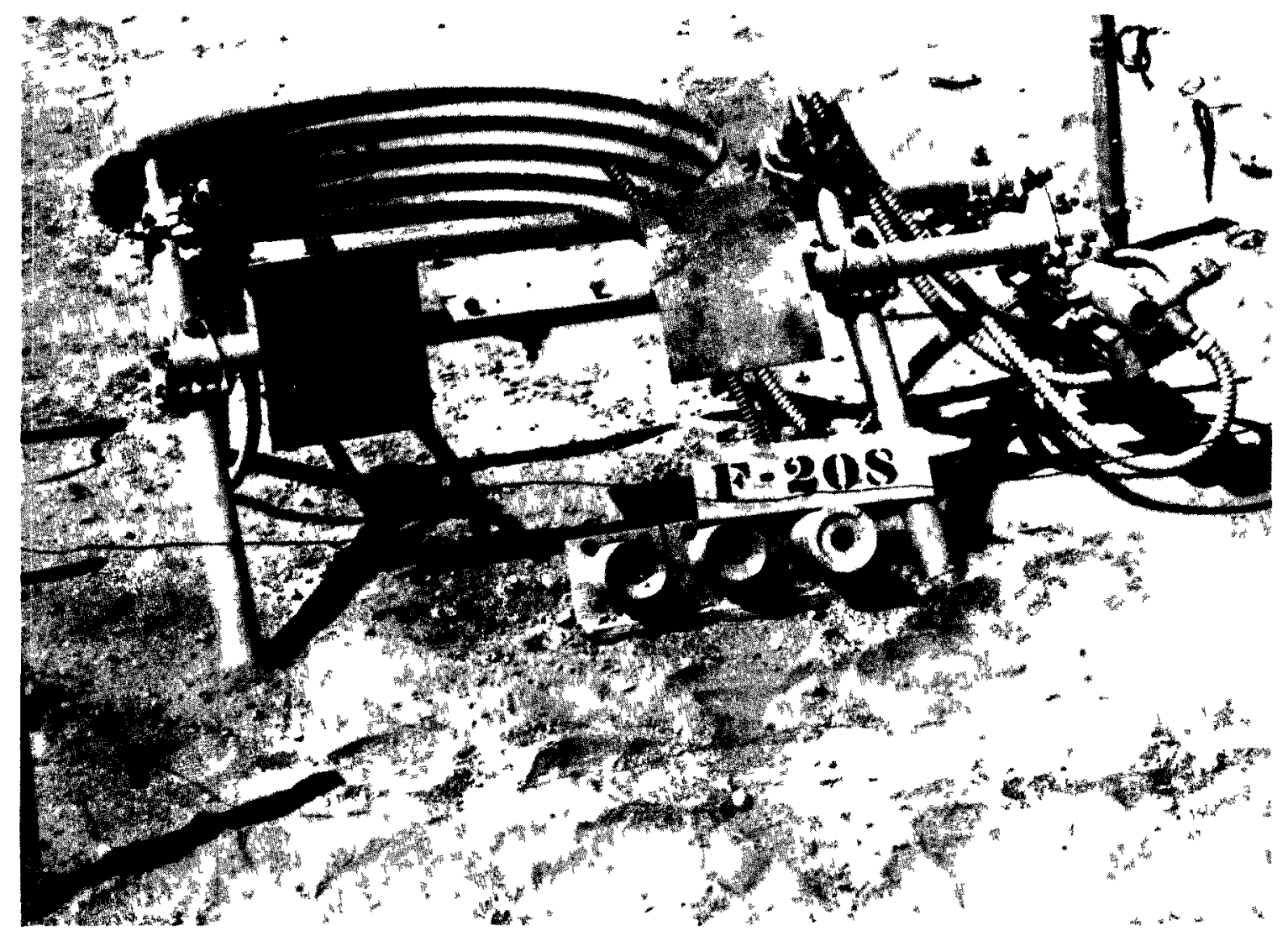

Fig. 2.12 Typical Ground Ievel Installation 


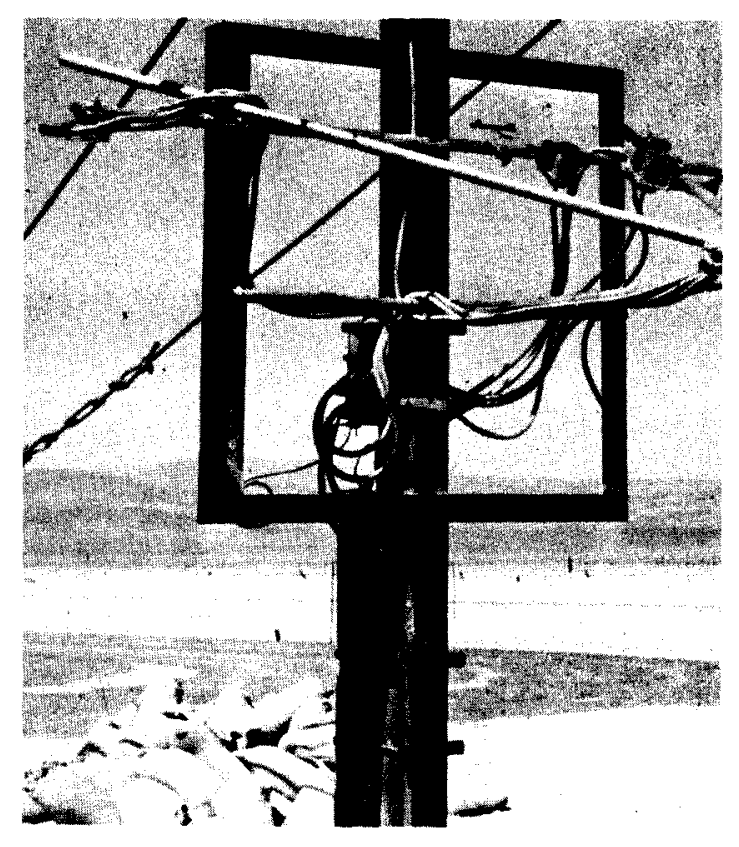

Fig. 2.13 Typical 10-ft Installation

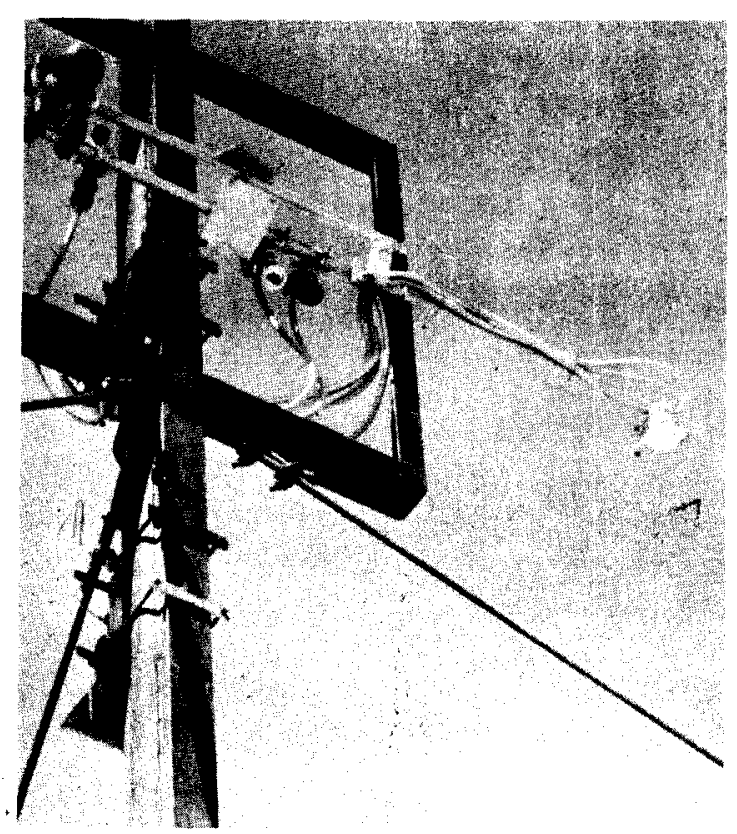

Fig. 2.14 Typical 50-ft Installation

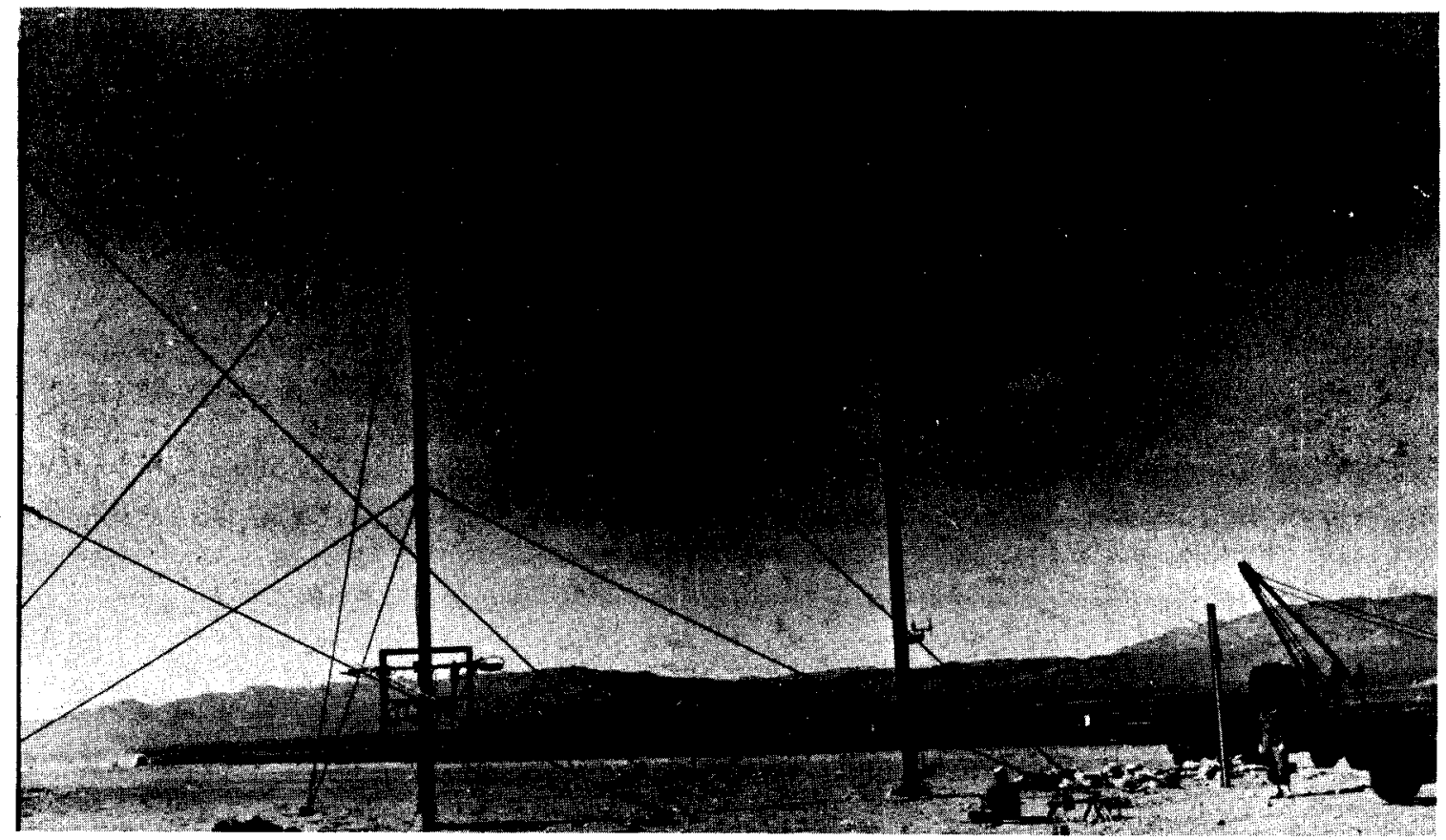

Fig. 2.15 Typical Station 


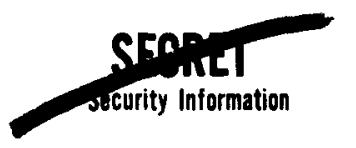

CHAPTER 3

CALIBRATION

\subsection{GENERAL}

The procedures used to calibrate the field instruments were of two essentially independent types: thermal and electrical. The thermal calibrations concerned the thermal properties of the measuring instrument itself, and were usually made by a comparison of the response of the instrument being calibrated with the known response of another instrument or laboratory standard. This comparison could involve visual observation of damage, as in the case of the passive receivers, or measurement of thermoelectric output, as in the case of the disk calorimeter or radiometer. Since there was little likelihood of a change in the thermal properties of the instruments after assembly, the thermal calibrations were generally performed in the laboratory, both before and after the field phases of the operation, with some check calibrations in the field.

In the case of the disk calorimeters and the radiometers, the thermal pulse generates an electrical signal. This signal is carried by a circuit and rucorded by a galvanometer which is not part of the detection device. An electrical calibration is necessary in addition to the thermal calibrations. The electrical calibration took into account the characteristics of the electrical circuit used to record the thermoelectric signal generated by the particular detection device. Consequently, this type of calibration was performed in the field using the circuits that were used during the test itself.

\subsection{THERMAL CALIBRATIONS}

The laboratory source and apparatus used for the thermal calibration of the instruments have been previously described2,3]. Briefly, the exposure equipment consists of a Navy 36-in. searchlight as a source of nearly parallel radiation, and a second searchlight mirror to collect this parallel radiation and bring it to a focus to form an image of the carbon. Exposure times are controlled either by a high-speed air shutter 6 , or by using a sweeping technique, i.e., by rotating the source so that the focused image streeps past the exposure aperture. Primary measurements of the energy delivered by the source were made with an absolute water-flow calorimeter $12 /$. The source was then used to calibrate certain secondary calorimeters ll, similar in design to those used in the field. A further check is obtained by comparing the experimental calibration of the secondary calorimeters with theoretical calculations based upon geometrical considerations and the properties of the calorimeter receiver.

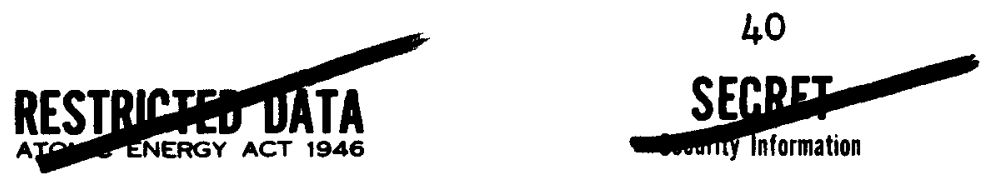




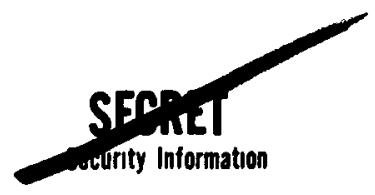

All of the instruments were given check calibrations in the field using a portable calibrator consisting of a 1,500-w Wolfram projection lamp and a 29-cm elliptical mirror with foci at 16 and $25 \mathrm{~cm}$ from its vertex 5 . This portable calibrator was also used for the primary calibration of some of the USNRDI disk radiometers.

\subsection{ELECTRICAL CALIBRATIONS}

Since it is impossible to set up in advance exact duplicates of the unknown field circuits, it becomes necessary to make electrical calibrations in the field. Because of the vast number of circuits to be calibrated in a limited time and with limited personnel, the Instruments Branch, Nacleonics Division, USNRDL, was asked to construct a calibration set that would maintain a high degree of accuracy under the strain of rough handling and field conditions.

The test set provided was capable of both the measurement of resistance, with a bridge circuit, and the generation of voltage signals from a low-impedance voltage generator. The set consisted of a Ioeds and Northrup 24-ohm galvanometer, a standard cell, a Burgess $1-1 / 2-v$ dry cell, and necessary switches and resistors. One circuit provides roltage signals of $1,2,3,4,5,10,20$, and $30 \mathrm{mv}$ with an accuracy of $0.005 \mathrm{mr}$ for an external resistance range of 20 to 110 ohms. A second circuit consists of a resistance bridge capable of an accuracy of 0.1 ohm over a range from 0 to 100 ohms. The voltage generation circuit is used for calibration purposes and the resistance bridge for the adjustment of circuit resistances to obtain proper damping for the galvanometer used for recording the signal. A circuit diagram is show in Fig. 3.1.

For circuit calibration, the field circuit was opened in the junction box, and the test leads attached so that the test set was connected in series in the circuit. The Heiland recorder was started and a calibration performed. This same procedure was followed for the other circuits of the recorder until all 12 circuits had been calibrated, the total process taking a little more than 10 min. Use of the test set made it possible to make calibrations in a short interval of time, an advantage that was particularly suited for the highly radioactive areas encountered in check calibrations made on the recovery trips folloring a detonation.

After the recording paper was developed, the calibrations were easily identified and measured. A typical set of calibrations takes about $10 \mathrm{ft}$ of recorder paper and can thus be run on the same roll of paper that is used during the actual test. The individual circuit calibration gives the deflection of the galvanometer produced by the roltage applied to the actual field circuit. For each circuit, the set of calibrations gives the degree of linearity of scale over the range of voltages to be encountered during the detonation. A typical calibration trace is show in Fig. 3.2. 

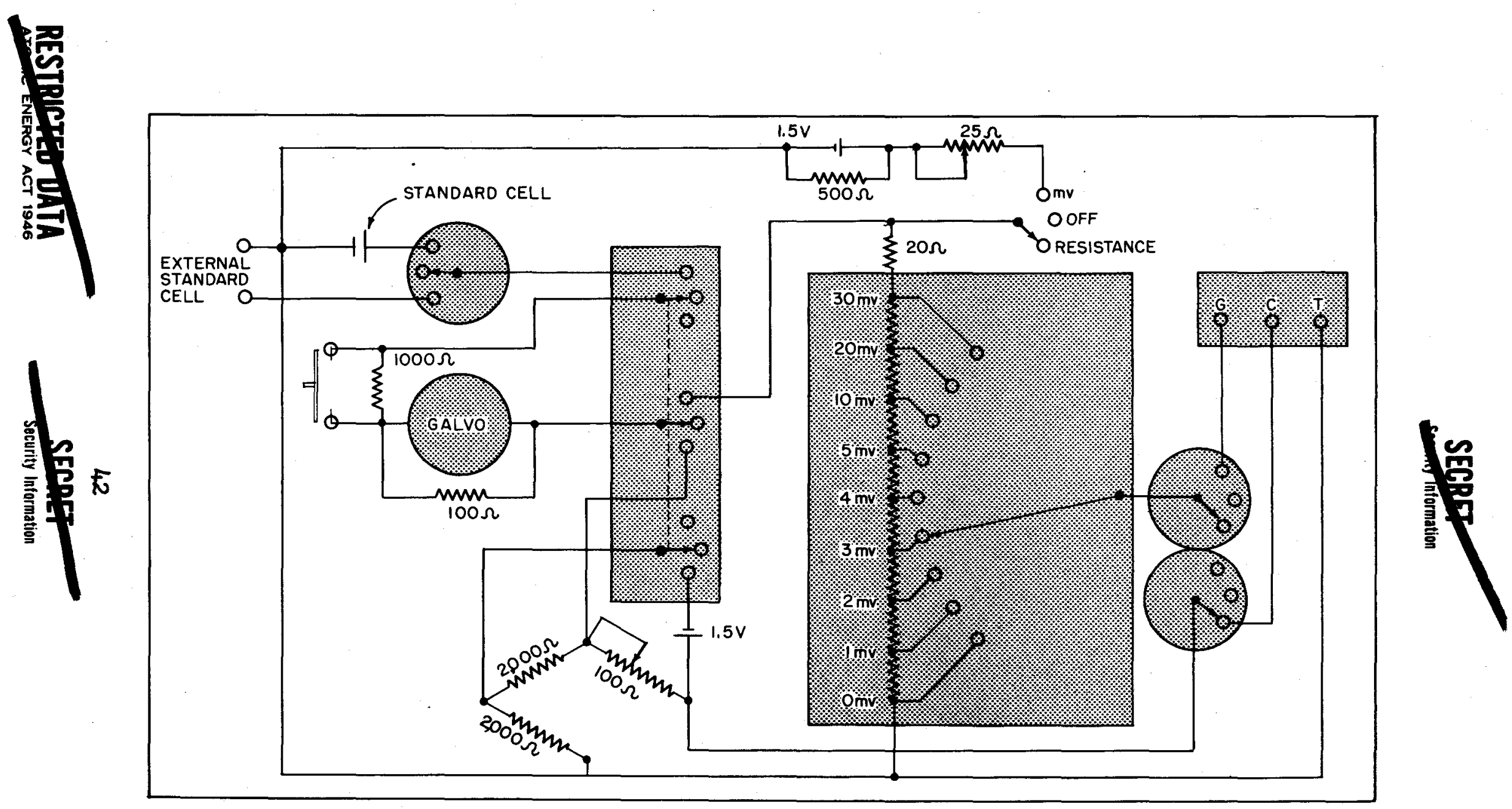

Fig. 3.1 Wiring Dlagram of Hectrical Test Set 


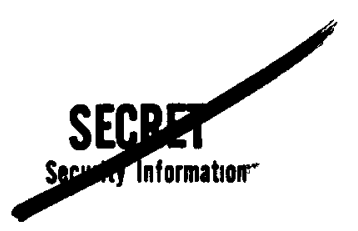

\subsection{FIEID CATORTMETERS}

The 36-in. searchlight source has a high degree of convergence (cone of approximately $60^{\circ}$ halfangle). The geometry of the calibrating equipment necessitated exposure of the receiving disk of the field calorimeter with filter removed. A further complication introduced by the high convergence was the fact that exposure of the field calorimeters, especially those with thick receivers, directly to this beam woulc result in a fairly large amount of energy striking the edges of the receivers. In order to eliminate the necessity for correcting for edge offects, a new aperture plate was designed for the lark VI laboratory secondary calorimeter which would also accommodate the field calorimeters. The aperture diameter and the aperture-receiver spacing were adjusted so that all the energy passing through the aperture hit the front surface of the receiver in both the laboratory and field instruments. The calibration factor of the field calorimeter is:

$$
\begin{aligned}
& \mathrm{k}(\mathrm{cal} / \mathrm{sq} \mathrm{cm} / \mathrm{mv})=\frac{A_{1}}{A_{2}} \cdot \frac{\nabla_{1}}{\nabla_{2}} \cdot k_{1}, \\
& \text { where } A_{1}=\text { Area of Mark VI aperture } \\
& A_{2}=\text { Area of field calorimeter } \\
& \text { receiver ( } \mathrm{sq} \mathrm{cm} \text { ), } \\
& \nabla_{1}=\text { Signal from Mark } \nabla I \text { wen } \\
& \text { exposed to beam (mv), } \\
& v_{2}=\text { Signal from field calo- } \\
& \text { rimeter when exposed to } \\
& \text { beam (mv), and }
\end{aligned}
$$

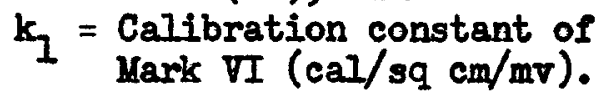

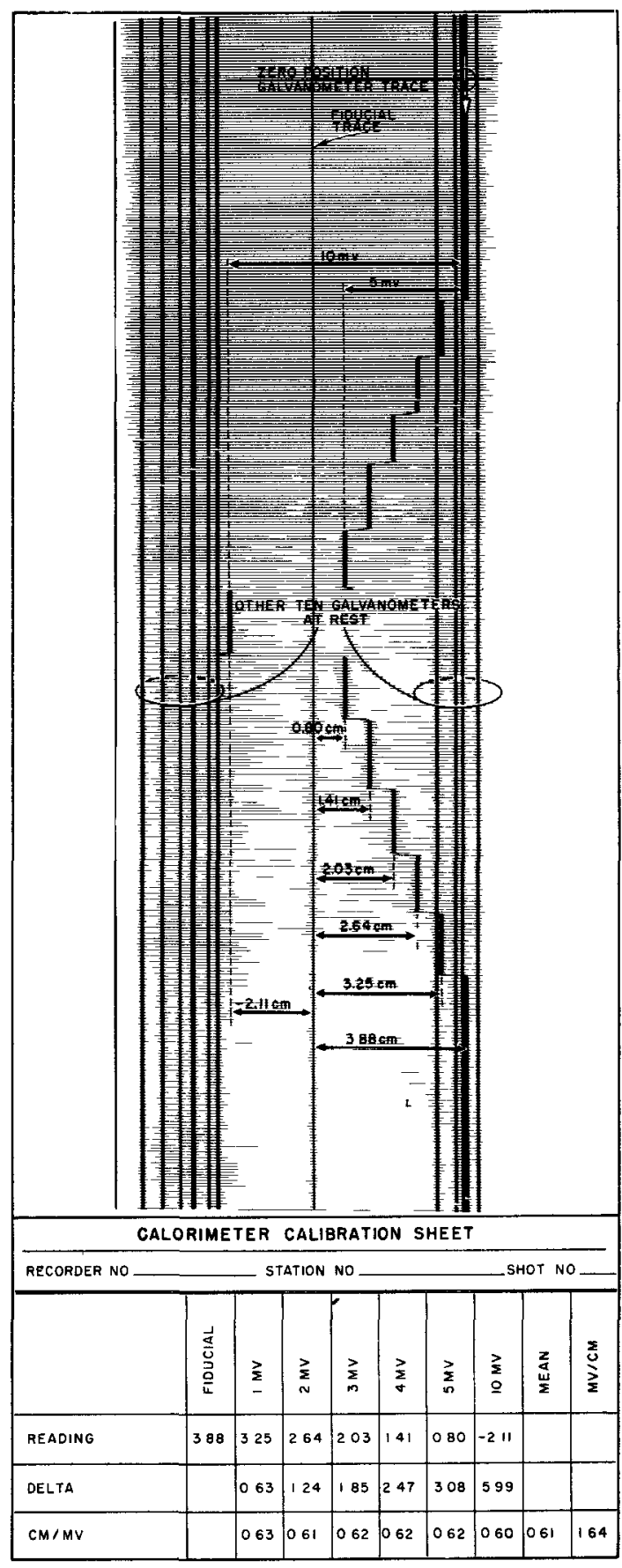

Fig. 3.2 Sample Calibration Record Obtained with Test Set 


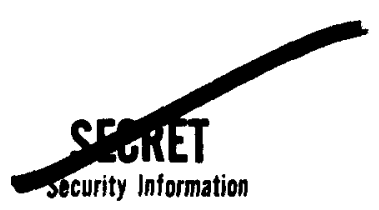

It is evident from the equation that this type of calibration necessitates an accurate measurement of the receiver area. However, it is felt that this measurement can be made mach more accurately than any type of correction for edge effects.

The signals produced by both the laboratory and field calorimeters were recorded, through a voltage divider, on a Brown Electronik Potentiometer with ranges of $0-0.5$ and $0-2.5 \mathrm{mv}$. In order to keep the decay corrections small, exposure times of 1 sec or less were used on all but the thickest (125-mil) disks, for which an exposure time of $2 \mathrm{sec}$ was used. As the pen speed of the recorder was such that the pen would travel full scale in approximately 3.3 sec, the roltage divider was adjusted so that the deflection was about $1 / 3$ full scale. Using this technique, equilibrium temperatures were established and recorded in a little over I sec for all cases except the thickest disks. The decay corrections in the calibration were therefore never more than a few per cent. Each calorimeter was calibrated at two energy levels in order to determine the influence of the change of thermoelectric power with temperature.

In addition to the experimental calibration, a theoretical calibration was made by weighing each disk and measuring the thermoelectric output of the thermocouple wire used. From this data, and taking the heat capacity of copper as $0.093 \mathrm{cal} / \mathrm{g} /{ }^{\circ} \mathrm{C}$ and an absorptivity of $I$ for the blackened face, the theoretical calibration factor was obtained from the formula:

$$
\mathrm{k}(\mathrm{cal} / \mathrm{sq} \mathrm{cm} / \mathrm{mv})=\frac{\mathrm{MC}}{\mathrm{AE}}
$$

where $\mathrm{M}=$ Mass of receiver $(\mathrm{g})$,

$A=$ Area of receiver $(\mathrm{sq} \mathrm{cm})$,

$C=$ Heat capacity of copper $\left(\mathrm{cal} / \mathrm{g} /{ }^{\circ} \mathrm{C}\right)$, and

$\mathbf{E}=$ Average thermoelectric power of the copper-constantan thermocouple over applicable temperature range (mv/ $/ 0$ ).

Table 3.1 gives the results of the experimental and theoretical determination of the calibration factor. Columns 2 and 3 give the experimentally-determined calibration factor for the two energy levels. Columns 4 and 5 give the experimental calibration factor per gram, and columns 6 and 7 give the theoretically-calculated calibration factor per gram using an average thermoelectric power over the temperature rise produced by the two energy levels. Columns 8 and 9 are the ratios of the experimental to the theoretical calibration factors. It can be seen that in no case is there as large a difference as 10 per cent between the experimental and theoretical factors and on the average the difference is only a few per cent. Column 10 is the average experimental calibration factor used. 
TABLE 3.1

Thermal Calibration Factors for Disk Calorimeters

\begin{tabular}{|c|c|c|c|c|c|c|c|c|c|c|}
\hline \multirow{2}{*}{\multicolumn{2}{|c|}{ Cal. No. }} & \multicolumn{2}{|c|}{$\begin{array}{l}\text { Exp. Calib. Factor } \\
\text { (cal/sq cm/mv) }\end{array}$} & \multicolumn{2}{|c|}{$\begin{array}{c}\text { Exp. Calib. } \\
\text { Factor per Gram } \\
\text { of Receiver } \\
\text { (cal } / \mathrm{sq} \mathrm{cm} / \mathrm{mv} / \mathrm{g} \text { ) }\end{array}$} & \multicolumn{2}{|c|}{$\begin{array}{l}\text { Theo. Calib. } \\
\text { Factor per Gram } \\
\text { of Receiver } \\
\text { (cal/sq cm/mv/g) }\end{array}$} & \multicolumn{2}{|c|}{$\begin{array}{c}\text { Ratio of Exp. } \\
\text { to Theo. Calib. } \\
\text { Factor }\end{array}$} & \multirow{2}{*}{$\begin{array}{c}\text { Av. Exp. } \\
\text { Calib. Factor } \\
\text { (cal/sq cm/mv) }\end{array}$} \\
\hline & & $\begin{array}{c}\text { High } \\
\text { Energy }(a)\end{array}$ & Energy $^{\text {Low }}$ & $\begin{array}{l}\text { High } \\
\text { Energy }\end{array}$ & $\begin{array}{l}\text { Low } \\
\text { Energy }\end{array}$ & $\begin{array}{c}\text { High } \\
\text { Energy }\end{array}$ & $\begin{array}{l}\text { Low } \\
\text { Energy }\end{array}$ & $\begin{array}{c}\text { High } \\
\text { Energy }\end{array}$ & $\begin{array}{c}\text { Low } \\
\text { Energy }\end{array}$ & \\
\hline \multirow[t]{13}{*}{ Red } & 2 & 5.28 & 5.97 & 2.64 & 2.98 & 2.86 & 3.00 & 0.92 & 0.99 & 5.62 \\
\hline & 3 & 5.67 & 6.01 & 2.67 & 2.84 & 2.86 & 3.00 & 0.93 & 0.96 & 5.84 \\
\hline & 4 & 5.67 & 6.22 & 2.82 & 3.10 & 2.86 & 3.00 & 0.99 & 1.03 & 5.95 \\
\hline & 5 & 5.92 & 6.24 & 2. 75 & 2.90 & 2,86 & 3.00 & 0.96 & 0.97 & 6.08 \\
\hline & 8 & 5,64 & 5.81 & 2. 74 & 2.82 & 2.86 & 3.00 & 0.96 & 0.94 & 5.72 \\
\hline & 9 & 5.79 & 6.25 & 2.73 & 2.95 & 2.86 & 3.00 & 0.96 & 0.98 & 6.02 \\
\hline & 10 & 5.43 & 6.18 & E. 62 & 2.98 & 2.86 & 3.00 & 0.92 & 0.99 & 5.80 \\
\hline & 12 & 5.64 & 6.18 & 2.71 & 2.97 & 2.86 & 3.00 & 0.95 & 0.99 & 5.91 \\
\hline & 13 & 5.58 & 5.91 & 2.66 & 2.81 & 2.86 & 3.00 & 0.93 & 0.94 & 5.74 \\
\hline & 14 & 5.33 & 5,60 & 2.68 & 2.82 & 2.86 & 3.00 & 0.94 & 0.94 & 5.47 \\
\hline & 15 & 5.38 & 5.51 & 2.65 & 2.72 & 2.86 & 3.00 & 0.93 & 0.91 & 5.45 \\
\hline & 16 & 5.22 & 5.32 & 2.73 & 2.79 & 2.86 & 3.00 & 0.96 & 0.93 & 5.27 \\
\hline & & & & & & & Av-- - & 0.95 & 0.96 & -- \\
\hline \multirow[t]{8}{*}{ Black } & 1 & 3.15 & 3.32 & 3.06 & 3.22 & 3.00 & 3.11 & 1.02 & 1.04 & 3. 24 \\
\hline & $\mathbf{2}$ & 3.21 & 3.40 & 3. 11 & 3.30 & 3.00 & 3.11 & 1.04 & 1.06 & 3.30 \\
\hline & 4 & 3.03 & 3.17 & 2.94 & 3.07 & 3.00 & 3.11 & 0.98 & 0.99 & 3.10 \\
\hline & 5 & 3. 01 & 3.11 & 2.90 & 2.99 & 3.00 & 3.11 & 0.97 & 0.96 & 3.06 \\
\hline & 7 & 3.19 & 3.20 & 3.07 & 3.08 & 3.00 & 3.11 & 1.02 & 0.99 & 3.20 \\
\hline & 8 & 3.15 & 3.20 & 3.06 & 3.10 & 3.00 & 3.11 & 1.02 & 1.00 & 3.18 \\
\hline & 9 & 3.14 & 3.10 & 3.08 & 3.04 & 3.00 & 3.11 & 1.03 & 0.98 & 3.12 \\
\hline & & & & & & & Av-- - & 1.01 & 1.00 & -- \\
\hline \multirow[t]{6}{*}{ White } & 1 & 1.43 & 1.44 & 2.82 & 2.84 & 2.93 & 3.11 & 0.96 & 0.91 & 1.44 \\
\hline & 2 & 1.46 & 1.53 & 2.87 & 3.01 & 2.93 & 3.11 & 0.98 & 0.97 & 1.50 \\
\hline & 3 & 1.45 & 1.55 & 2.82 & 3.02 & 2.93 & 3. 11 & 0.96 & 0.97 & 1.50 \\
\hline & 4 & 1.45 & 1.62 & 2.85 & 3.18 & 2.93 & 3.11 & 0.97 & 1.02 & 1.54 \\
\hline & 5 & 1.42 & 1.49 & 2.77 & 2.91 & 2.93 & 3.11 & 0.95 & 0.94 & 1.46 \\
\hline & & & & & & & Av--- & 0.96 & 0.96 & -- \\
\hline \multirow[t]{7}{*}{ Grey } & 1 & 1.16 & 1.15 & 3.00 & 2.98 & 2.82 & 3.06 & 1.06 & 0.97 & 1.16 \\
\hline & 2 & 1.18 & 1.18 & 2. 96 & 2.96 & 2.82 & 3.06 & 1.05 & 0.97 & 1.18 \\
\hline & 3 & 1.09 & 1.13 & 2.82 & 2.93 & 2.82 & 3.06 & 1.00 & 0.96 & 1.11 \\
\hline & 4 & 1. 13 & 1.20 & 2.90 & 3.08 & 2.82 & 3.06 & 1.03 & 1.01 & 1.16 \\
\hline & 5 & 1.07 & 1.10 & 2.77 & 2.85 & 2.82 & 3.06 & 0.98 & 0.93 & 1.08 \\
\hline & 6 & 1.18 & 1.24 & 2.99 & 3.14 & 2.82 & 3. 06 & 1.06 & 1.03 & 1.21 \\
\hline & 7 & 1.12 & 1.14 & 2.90 & 2.95 & 2.82 & 3.06 & 1.03 & 0.96 & 1.13 \\
\hline
\end{tabular}




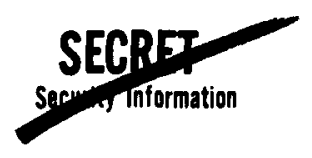

TABLE 3.1 (Continued)

Thermal Calibration Factors for Disk Calorimeters

\begin{tabular}{|c|c|c|c|c|c|c|c|c|c|c|}
\hline \multirow{2}{*}{\multicolumn{2}{|c|}{ Ca1. No. }} & \multicolumn{2}{|c|}{$\begin{array}{l}\text { Exp. Calib. Factor } \\
(\mathrm{cal} / \mathrm{sq} \mathrm{cm} / \mathrm{mv})\end{array}$} & \multicolumn{2}{|c|}{$\begin{array}{l}\text { Exp. Calib. } \\
\text { Factor per Gram } \\
\text { of Receiver } \\
\text { (cal/sq } \mathrm{cm} / \mathrm{mv} / \mathrm{g} \text { ) }\end{array}$} & \multicolumn{2}{|c|}{$\begin{array}{c}\text { Theo. Calib. } \\
\text { Factor per Gram } \\
\text { of Receiver } \\
\text { (cal/sq } \mathrm{cm} / \mathrm{mv} / \mathrm{g} \text { ) }\end{array}$} & \multicolumn{2}{|c|}{$\begin{array}{l}\text { Ratio of Exp. } \\
\text { to Theo. Calib. } \\
\text { Factor }\end{array}$} & \multirow{2}{*}{$\begin{array}{c}\text { Av. Exp. } \\
\text { Calib. Factor } \\
\text { (cal/sq cm/mv) }\end{array}$} \\
\hline & & $\begin{array}{l}\text { High } \\
\text { Energy (a) }\end{array}$ & $\begin{array}{c}\text { Low } \\
\text { Energy } \\
(b)\end{array}$ & $\begin{array}{c}\text { High } \\
\text { Energy }\end{array}$ & $\begin{array}{l}\text { Low } \\
\text { Energy }\end{array}$ & $\begin{array}{l}\text { High } \\
\text { Energy }\end{array}$ & $\begin{array}{c}\text { Low } \\
\text { Energy }\end{array}$ & $\begin{array}{c}\text { High } \\
\text { Energy }\end{array}$ & $\begin{array}{c}\text { Low } \\
\text { Energy }\end{array}$ & \\
\hline & 8 & 1.14 & 1.17 & 3.00 & 3.08 & 2.82 & 3.06 & 1.06 & 1.01 & 1.16 \\
\hline & 9 & 1.11 & 1.22 & 2.79 & 3.06 & 2.82 & 3.06 & 0.99 & 1.00 & 1.16 \\
\hline & 10 & 1.16 & 1.23 & 2.93 & 3.11 & 2.82 & 3.06 & 1.04 & 1.02 & 1.20 \\
\hline & 11 & 1.19 & 1.15 & 3.06 & 2.96 & 2.82 & 3.06 & 1.09 & 0.97 & 1.17 \\
\hline & 12 & 1.11 & 1.18 & 2.85 & 3.03 & 2.82 & 3.06 & 1.01 & 0.99 & 1.14 \\
\hline & 13 & 1.10 & 1.16 & 2.85 & 3.00 & 2.82 & 3.06 & 1.01 & 0.98 & 1.13 \\
\hline & 14 & 1.14 & 1.18 & 2.95 & 3.06 & 2.82 & 3.06 & 1.05 & 1.00 & 1.16 \\
\hline & & & & & & & Av--- & 1.03 & 0.98 & -- \\
\hline Erass & s 1 & 0.94 & 0.98 & 2.99 & 3.12 & 3.04 & 3.20 & 0.98 & 0.98 & 0.96 \\
\hline & 3 & 0.97 & 1.10 & 3.05 & 3.46 & 3.04 & 3.20 & 1.00 & 1.08 & 1.04 \\
\hline & 6 & 0.95 & 1.02 & 3.06 & 3.28 & 3.04 & 3.20 & 1.01 & 1.02 & 0.98 \\
\hline & 8 & 0.93 & 0.93 & 2.99 & 2.99 & 3.04 & 3.20 & 0.98 & 0.93 & 0.93 \\
\hline & & & & & & & Av- - & 0.99 & 1.00 & -. \\
\hline
\end{tabular}

(a) The nigh energies delivered were $23,12,7,7$, and $7 \mathrm{cal} / \mathrm{sq} \mathrm{cm}$ for the Red, Black, White, Grey, and Brass calorimeters, respectively.

(b) The low energies delivered were $11,7,3,3$, and $3 \mathrm{cal} / \mathrm{sq} \mathrm{cm}$ for. the Red, Black, White, Grey, and Brass calorimeters, respectively.

As can be seen from Table 3.1 the calibration factor is not constant, owing to the slight change in thermoelectric power with temperature. Practically, however, the use of an average value leads to no appreciable error over the limited temperature range normally covered by the calorimeters. In those few cases where abnormally small or large signals were obtained, a small correction was applied on the basis of the experimentallydetermined thermoelectric power.

\subsection{RADIOMETERS}

only the MIT-3 radiometer was calibrated with the laboratory thermal source, as the other radiameters were not completed until after departure for the field. The other radiometers were calibrated(between shots 2 and 3 using the portable calibrator. The voltage on the callbeatermos milintained at a constant value and the calibration factors 


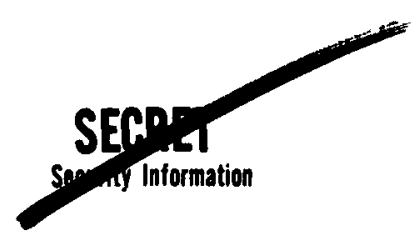

were determined by taking the ratio of the deflections of the various radiometers to the deflection obtained by the NIT-3. The results of the disk radiometer calibrations are shown in Table 3.2 .

TABLE 3.2

Calibration Factors for Disk Radiometers (Field)

\begin{tabular}{|l|c|}
\hline \hline Instrument & $\begin{array}{c}\text { Calibration Factor } \\
\text { (cal/sq cm/sec/mv) }\end{array}$ \\
\hline MIT-3 & $2.9(\mathrm{a})$ \\
USNRDI K-1 & 5.9 \\
USNRDL K-2 & 2.8 \\
USNRDL K-3 & 4.8 \\
USNRDI K-5 & 2.9 \\
USNRDL K-8 & 3.3 \\
\hline
\end{tabular}

(a)

Obtained using laboratory source.

\subsection{PASSIVE RECEIVERS}

To use the series of blackened metal foils as a measuring device it is necessary to be able to assign a value to the energy pulse which is bracketed by two foils in a series. This value may be determined in one of two ways, neither of which is as simple as may appear at first glance. The first method, a theoretical approach, is to calculate, using knom constants of the metal and heat transfer equations, the energy necessary to produce a given effect upon anj foil. To date, the appropriate equations and constants are not sufficiently well known to allow much faith in calculations of this type. The other method, an empirical approach, involves the measurement of effects on foils using a known source of thermal radiation. This procedure is strictly accurate only if all important parameters in both the calibrating exposure and the measurement exposure are carefully controlled.

A discussion of current estimates of the importance of the various parameters may be found in the report on Operation GREENHOUSE. Perhaps the most important variable which has not been eliminated, and which has been found to affect seriously the quantity of thermal energy necessary to produce a certain effect on a metal foll, is the time in which this energy is received. For each effect on a given metal foil there exists not only one critical energy, but a curve of critical energy rs time. Before a series of folls could be used to determine a unique energy value, for an unknown radiant energy pulse, it would be necessary to obtain the time and shape of this pulse.

The passive receivers were calibrated in the laboratory by exposure to the 36-in. searchlight source. Calibration curves showing critical 
energy vs time of exposure, as defined in the Operation GREENHOUSE report, were obtained for all thicknesses of the five metals used. The critical effects were selected on the basis of reproducibility and ease of determination.

The criteria for threshold, as previously determined during calibration, were first surface-melt for cadmiun, and first melt-through for the other metals. For the three-legged disks, surface-melt was substituted for melt-through as the criterion for tin. Distortion of the edge of the strip had been chosen as the silver-strip threshold. Application of these criteria to damage produced by the incident radiation, in the laboratory and in the field, enable an estimation to be made of the energy received by the series of foils during the detonation. 


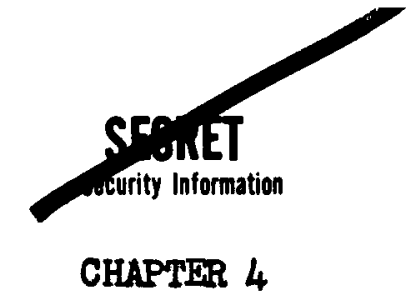

\section{RESULTS}

\subsection{GENERAL}

After each detonation the shot area was re-entered at the earliest moment following clearance by the Radiological Safety group. The recorder paper and foil panels were recovered, and the readings on the sphere calorimeters were recorded.

Some loss of data occurred because of the unsatisfactory operation of two of the Heiland recorders. (For Shot 1 . one of the recorders used at Station 202 failed to operate, and a second operated intermittently. Wh the case of Shot 20 one of the recorders used for Station 204 failed to opurate satisfactorily. Since this was the same recorder that operated intermittently auring shot 1 it was replaced (prior to shot 3) by a new one, procured Irom the Heiland Research Corporition. All of the recorders operated satisfactorily on shots 3 and 4. Very little usable data were obtained at Station 7-202, Shot 4, as the shock rave completely destroyed the station. No electrical pickup of magnitude sufficiently high to negate total energy determinations was observed except at station 7-202 shot 2. where several types of cable were used as a check on the shielding protection afforded hr the rarious types of cables. The pickup recorded at Station 7-204, Shot 4 however, was sufficiently high to render questionable the intensity-time curves from some of the calorimeters at this station.

\subsection{CALORDETERS}

The data from the original Heiland tracings were obtained using the Universal Telereader. These data were used to plot intensity-rs-time curves and to obtain total energy values for each calorimeter. The total energy recelved by each calorimeter disk is given in Tables 4.1 through 4.4. In these tables, column 1 gives the station number, column 2 the slant range from point of detonation, column 3 the field of view of the calorimeter, column 4 the orientation, column 5 the angle from horizontal, column 6 the elevation, column 7 the calorimeter number, column 8 the type of filter used, column 9 the total energy received under the filter, and column 10 the total energy incident on the calorimeter in the wave length region defined by the filter used. The values reported in column 10 are obtained by making corrections to the values in column 9 for the transmission of the filters in the flat portions of their transmission curres. This correction amounted to about 8 per cent for quartz, 8 per cent for $9-54,8$ per cent for $0-52,10$ per cent for $3-69,12$ per cent for $2-58$, and 12 per cent for $7-56$. 
TABLE 4.1

Calorimeter Results, Shot 1

\begin{tabular}{|c|c|c|c|c|c|c|c|c|c|}
\hline Station & $\begin{array}{l}\text { Slant } \\
\text { Range } \\
\text { (ft) }\end{array}$ & $\begin{array}{l}\text { Half- } \\
\text { angle } \\
\text { of Field } \\
\text { of View } \\
\text { (deg) }\end{array}$ & $\begin{array}{c}\text { Orienta- } \\
\text { tion(a) }\end{array}$ & $\begin{array}{l}\text { Angle from } \\
\text { Horizontal } \\
\text { (deg) }\end{array}$ & $\begin{array}{c}\text { Elevation } \\
\text { (ft) }\end{array}$ & Cal. No. & Filter & $\begin{array}{l}\text { Total Energy } \\
\text { under Filter } \\
\text { (cal/sq cm) }\end{array}$ & $\begin{array}{l}\text { Total Energy } \\
\text { Incident(b) } \\
\text { (cal/sq cm) }\end{array}$ \\
\hline \multirow[t]{3}{*}{ F-202 } & $\begin{array}{l}970 \\
980 \\
980\end{array}$ & $\begin{array}{l}45 \\
45 \\
45\end{array}$ & $\begin{array}{l}\text { AZ } \\
\text { AZ } \\
\text { AZ }\end{array}$ & $\begin{array}{l}+58 \\
+58 \\
+58\end{array}$ & $\begin{array}{r}10 \\
0 \\
0\end{array}$ & $\begin{array}{l}\text { Red } 3 \\
\text { Red } 6 \\
\text { Red } 5\end{array}$ & $\begin{array}{l}\text { Quartz } \\
\text { Quartz } \\
\text { Quartz }\end{array}$ & \multicolumn{2}{|c|}{$\begin{array}{l}\text { Recorder Failure } \\
\text { Recorder Failure } \\
\text { Recorder Failure }\end{array}$} \\
\hline & $\begin{array}{l}940 \\
970 \\
980\end{array}$ & $\begin{array}{l}30 \\
30 \\
30\end{array}$ & $\begin{array}{l}\mathrm{AZ} \\
\mathrm{AZ} \\
\mathrm{AZ}\end{array}$ & $\begin{array}{l}+58 \\
+58 \\
+58\end{array}$ & $\begin{array}{r}50 \\
10 \\
0\end{array}$ & $\begin{array}{l}\text { Red } 9 \\
\text { Red } 2 \\
\text { Red } 4\end{array}$ & $\begin{array}{l}\text { Quartz } \\
\text { Quartz } \\
\text { Quartz }\end{array}$ & \multicolumn{2}{|c|}{$\begin{array}{l}42.6 \\
\text { Recorder Failure } \\
\text { Recorder Failure }\end{array}$} \\
\hline & $\begin{array}{l}940 \\
940\end{array}$ & $\begin{array}{l}45 \\
15\end{array}$ & $\begin{array}{l}\text { GR } \\
\text { GR }\end{array}$ & $\begin{array}{l}-58 \\
-58\end{array}$ & $\begin{array}{l}50 \\
50\end{array}$ & $\begin{array}{l}\text { Black } 1 \\
\text { Black } \frac{2}{2}\end{array}$ & $\begin{array}{l}\text { Quartz } \\
\text { Quartz }\end{array}$ & $\begin{array}{l}7.0 \\
0.59\end{array}$ & $\begin{array}{l}7.6 \\
0.64\end{array}$ \\
\hline \multirow[t]{3}{*}{ F-208 } & $\begin{array}{l}2,210 \\
2,220 \\
2,220\end{array}$ & $\begin{array}{l}45 \\
45 \\
45\end{array}$ & $\begin{array}{l}A Z \\
A Z \\
A Z\end{array}$ & $\begin{array}{l}+21 \\
+21 \\
+21\end{array}$ & $\begin{array}{r}10 \\
0 \\
0\end{array}$ & $\begin{array}{l}\text { Grey } 3 \\
\text { Grey } 6 \\
\text { Grey } 5\end{array}$ & $\begin{array}{l}\text { Quartz } \\
\text { Quartz } \\
\text { Quartz }\end{array}$ & $\begin{array}{l}8.0 \\
7.5 \\
6.9\end{array}$ & $\begin{array}{l}8.7 \\
8.7 \\
7.5\end{array}$ \\
\hline & $\begin{array}{l}2,200 \\
2,210 \\
2,220\end{array}$ & $\begin{array}{l}15 \\
15 \\
15\end{array}$ & $\begin{array}{l}A Z \\
A Z \\
A Z\end{array}$ & $\begin{array}{l}+21 \\
+21 \\
+21\end{array}$ & $\begin{array}{r}50 \\
10 \\
0\end{array}$ & $\begin{array}{l}\text { Grey } 1 \\
\text { Grey } 2 \\
\text { Grey } 4\end{array}$ & $\begin{array}{l}\text { Quartz } \\
\text { Quartz } \\
\text { Quartz }\end{array}$ & $\begin{array}{l}7.0 \\
6.7 \\
-0-\end{array}$ & $\begin{array}{l}7.6 \\
7.2 \\
-0-\end{array}$ \\
\hline & $\begin{array}{l}2,200 \\
2,200 \\
\end{array}$ & $\begin{array}{l}45 \\
15\end{array}$ & $\begin{array}{l}\text { GR } \\
\text { GR }\end{array}$ & $\begin{array}{l}-21 \\
-21 \\
\end{array}$ & $\begin{array}{l}50 \\
50\end{array}$ & $\begin{array}{l}\text { Brass } 1 \\
\text { Brass } 8\end{array}$ & $\begin{array}{l}\text { Quartz } \\
\text { Quartz }\end{array}$ & $\begin{array}{l}5.1(\mathrm{c}) \\
0.14\end{array}$ & $\begin{array}{l}5.5^{(c)} \\
0.15\end{array}$ \\
\hline
\end{tabular}

(a) $\mathrm{AZ}=$ Calorimeter aligned toward air zero. $\mathrm{GR}=$ Calorimeter aligned to measure radiation reflected from the ground in front of station.

(b) Not corrected for atmospheric attemuation.

(c) Field of view included part of the fire ball energy as well as the energy reflected from the ground.

TABLE 4.2

Calorimeter Results Shot 2

\begin{tabular}{|c|c|c|c|c|c|c|c|c|c|}
\hline Station & $\begin{array}{c}\text { Slant } \\
\text { Range } \\
\text { (ft) }\end{array}$ & $\begin{array}{l}\text { Half- } \\
\text { angle } \\
\text { of Field } \\
\text { of View } \\
\text { (deg) }\end{array}$ & $\begin{array}{l}\text { Orienta- } \\
\text { tion(a) }\end{array}$ & $\begin{array}{c}\text { Angle from } \\
\text { Horizontal } \\
\text { (deg) }\end{array}$ & $\begin{array}{c}\text { Elevation } \\
\text { (ft) }\end{array}$ & Cal. No. & Filter & $\begin{array}{l}\text { Total Energy } \\
\text { under Filter } \\
\text { (cal/sq cm) }\end{array}$ & $\begin{array}{l}\text { Total Energy } \\
\text { Incident(b) } \\
(\mathrm{cal} / \mathrm{sq} \mathrm{cm})\end{array}$ \\
\hline $7-202$ & $\begin{array}{l}1,760 \\
1,760 \\
1,760 \\
1,760\end{array}$ & $\begin{array}{l}45 \\
45 \\
45 \\
45\end{array}$ & $\begin{array}{l}A Z \\
A Z \\
A Z \\
A Z\end{array}$ & $\begin{array}{l}+36 \\
+36 \\
+36 \\
+36\end{array}$ & $\begin{array}{l}10 \\
10 \\
10 \\
10\end{array}$ & $\begin{array}{l}\text { White } 4 \\
\text { White } 1 \\
\text { White } 5 \\
\text { White } 3\end{array}$ & $\begin{array}{l}\text { Quartz } \\
\text { Quartz } \\
\text { Quartz } \\
\text { Quartz }\end{array}$ & $\begin{array}{l}11.9 \\
11.2 \\
10.5 \\
\text { Galvanome }\end{array}$ & $\begin{array}{l}12.9 \\
12.2 \\
11.4 \\
\text { burn-out }\end{array}$ \\
\hline \multirow[t]{2}{*}{$7-204$} & $\begin{array}{l}3,070 \\
3,080 \\
3,080 \\
3,080\end{array}$ & $\begin{array}{l}45 \\
45 \\
45 \\
45\end{array}$ & $\begin{array}{l}A Z \\
A Z \\
A Z \\
A Z\end{array}$ & $\begin{array}{l}+20 \\
+20 \\
+20 \\
+20\end{array}$ & $\begin{array}{r}10 \\
0 \\
0 \\
0\end{array}$ & $\begin{array}{l}\text { Grey } 5 \\
\text { Brass } 3 \\
\text { Grey } 2 \\
\text { Grey } 1\end{array}$ & $\begin{array}{l}\text { Quartz } \\
\text { Quartz } \\
\text { Quartz } \\
\text { Quartz }\end{array}$ & $\begin{array}{l}3.7 \\
4.1 \\
3.9 \\
4.0\end{array}$ & $\begin{array}{l}4.0 \\
4.5 \\
4.3 \\
4.4\end{array}$ \\
\hline & $\begin{array}{l}3,050 \\
3,050\end{array}$ & $\begin{array}{l}15 \\
45\end{array}$ & $\stackrel{A Z}{G R}$ & $\begin{array}{r}+20 \\
-57\end{array}$ & $\begin{array}{l}50 \\
50\end{array}$ & $\begin{array}{l}\text { Brass } 8 \\
\text { Brass } 1\end{array}$ & $\begin{array}{l}\text { Quartz } \\
\text { Quartz }\end{array}$ & $\begin{array}{l}3.2 \\
0.27\end{array}$ & $\begin{array}{l}3.5 \\
0.29\end{array}$ \\
\hline
\end{tabular}

(a) $\mathrm{AZ}=$ Calorimeter aligned toward air zero. $\mathrm{GR}=$ Calorimeter aligned to masure radiation reflected from the ground in front of atation.

(b) Not corrected for atmospheric attenuation. 


\section{TABIE 4.3}

\section{Calorimeter Results, (Shot 3}

\begin{tabular}{|c|c|c|c|c|c|c|c|c|c|}
\hline Station & $\begin{array}{c}\text { Slant } \\
\text { Range } \\
(\mathrm{ft})\end{array}$ & $\begin{array}{c}\text { Half- } \\
\text { angle } \\
\text { of Field } \\
\text { of View } \\
\text { (deg) }\end{array}$ & $\begin{array}{c}\text { Orienta- } \\
\text { tion(a) }\end{array}$ & $\begin{array}{c}\text { Angle from } \\
\text { Horizontal } \\
\text { (deg) }\end{array}$ & $\begin{array}{l}\text { Elevation } \\
\text { (ft) }\end{array}$ & Cal. No. & Filter & $\begin{array}{l}\text { Total Energy } \\
\text { under Filter } \\
(\mathrm{cal} / \mathrm{sq} \mathrm{cm})\end{array}$ & $\begin{array}{l}\text { Total Energy } \\
\text { Incident }(\mathrm{b}) \\
(\mathrm{cal} / \mathrm{sq} \mathrm{cm})\end{array}$ \\
\hline $7-202$ & 3,440 & 45 & $\mathbf{A Z}$ & +66 & 10 & Red 11 & Quartz & 31.7 & 34.5 \\
\hline \multirow[t]{8}{*}{$7-204$} & 4,500 & 45 & $A Z$ & +48 & 10 & Red 12 & Quartz & 36.9 & 40.1 \\
\hline & 4,510 & 45 & $A Z$ & +48 & 0 & Red 14 & Quartz & 31.7 & 34.5 \\
\hline & 4,510 & 45 & $\mathbf{A Z}$ & +48 & 0 & Red 15 & Quartz & 30.8 & 33.5 \\
\hline & 4,470 & 15 & $A Z$ & +48 & 50 & $\operatorname{Red} 9$ & Quartz & 34.6 & 37.7 \\
\hline & 4,500 & 15 & $A Z$ & +48 & 10 & $\operatorname{Red} 4$ & Quartz & 31.7 & 34.5 \\
\hline & 4,510 & 15 & $A Z$ & +48 & 0 & Red 13 & Quartz & 13.0 & 14.1 \\
\hline & 4,470 & 45 & GR & -50 & 50 & Black 3 & Quartz & 0.57 & 0.62 \\
\hline & 4,470 & 15 & GR & -50 & 50 & Black 4 & Quartz & 0.37 & 0.40 \\
\hline \multirow[t]{5}{*}{$7-208$} & 6,810 & 45 & $\mathbf{A Z}$ & +29 & 50 & Black 6 & Quartz & 17.8 & 19.4 \\
\hline & 6,830 & 45 & AZ & +29 & 0 & Black 2 & Quartz & 16.6 & 18.1 \\
\hline & 6,830 & 7.5 & $A Z$ & +29 & 10 & Black 7 & Quartz & 9.9 & 10.8 \\
\hline & 6,830 & 7.5 & $A Z$ & +29 & 0 & Black 1 & Quartz & 7.6 & 8.3 \\
\hline & 6,810 & 45 & GR & -50 & 50 & Black 5 & Quartz & 1.7 & 1.9 \\
\hline \multirow[t]{6}{*}{$7-210$} & 9,530 & 45 & $A Z$ & +20 & 10 & White 1 & Quartz & 8.3 & 8.9 \\
\hline & 9,530 & 45 & $A Z$ & +20 & 10 & $\begin{array}{l}\text { White } 3 \\
\text { White } 4^{(c)}\end{array}$ & $\begin{array}{c}\text { Quartz } \\
0-52\end{array}$ & 0.78 & 0.84 \\
\hline & 9,530 & 45 & $\mathbf{A Z}$ & +20 & 10 & Grey 7 & $3-69$ & 5.7 & 6.3 \\
\hline & 9,530 & 45 & $\mathbf{A Z}$ & +20 & 10 & Grey 8 & $2-58$ & 4.3 & 4.9 \\
\hline & 9,530 & 45 & $A Z$ & +20 & 10 & Brass 3 & Spec. & 2.8 & 3.9 \\
\hline & 9,530 & 45 & $A Z$ & +20 & 10 & Brass 8 & $7-56$ & 2.0 & 2.3 \\
\hline \multirow[t]{3}{*}{ USFS } & 18,300 & 30 & $\mathbf{A Z}$ & +10 & 3 & Grey 12 & Quartz & 2.0 & 2.2 \\
\hline & 18,300 & 30 & $A Z$ & +10 & 3 & Brass 1 & Quartz & 2.0 & 2.2 \\
\hline & 18,300 & 30 & $A Z$ & +10 & 3 & Grey $6+13$ & Quartz & --- &.-- \\
\hline
\end{tabular}

(a) $A Z=$ Calorimeter aligned toward air zero. $G R=$ Calorimeter aligned to measure radiation reflected from the ground in front of station.

(b) Not corrected for atmospheric attenuation.

(c) Calorimeters connected in series but with opposite polarity.

51 


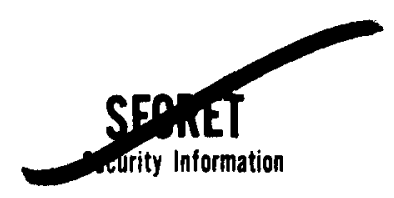

TABLE 4.4

Calorimeter Results, Shot 4

\begin{tabular}{|c|c|c|c|c|c|c|c|c|c|}
\hline Station & $\begin{array}{c}\text { Slant } \\
\text { Range } \\
(\mathrm{ft})\end{array}$ & $\begin{array}{c}\text { Half- } \\
\text { angle } \\
\text { of Field } \\
\text { of View } \\
\text { (deg) }\end{array}$ & $\begin{array}{c}\text { Orienta- } \\
\text { tion(a) }\end{array}$ & $\begin{array}{c}\text { Angle from } \\
\text { Horizontal } \\
\text { (deg) }\end{array}$ & $\begin{array}{c}\text { Elevation } \\
\text { (ft) }\end{array}$ & Cal. No. & Filter & $\begin{array}{l}\text { Total Energy } \\
\text { under Filter } \\
\text { (cal/sq cm) }\end{array}$ & $\begin{array}{l}\text { Total Energy } \\
\text { Incident(b) } \\
\text { (cal/sq cm) }\end{array}$ \\
\hline $7-202$ & 1,700 & 45 & AZ & +38 & 10 & Red 11 & Quartz & $63.4(\mathrm{c})$ & $69.0(c)$ \\
\hline \multirow[t]{4}{*}{$7-204$} & $\begin{array}{l}3,010 \\
3,020 \\
3,020\end{array}$ & $\begin{array}{l}45 \\
45 \\
45\end{array}$ & $\begin{array}{l}\mathbf{A Z} \\
\mathbf{A Z} \\
\mathbf{A Z}\end{array}$ & $\begin{array}{l}+21 \\
+21 \\
+21\end{array}$ & $\begin{array}{r}10 \\
0 \\
0\end{array}$ & $\begin{array}{l}\text { Red } 12 \\
\text { Red } 14 \\
\text { Red } 15\end{array}$ & $\begin{array}{l}\text { None } \\
\text { Quartz } \\
\text { Quartz }\end{array}$ & $\begin{array}{l}50.3 \\
39.6 \\
40.1\end{array}$ & $\begin{array}{l}50.3 \\
43.2 \\
43.6\end{array}$ \\
\hline & 2,990 & 30 & $\mathbf{A Z}$ & +21 & 50 & $\operatorname{Red} 9$ & Quartz & 53.2 & 57.8 \\
\hline & $\begin{array}{l}3,010 \\
3,020\end{array}$ & $\begin{array}{l}15 \\
15\end{array}$ & $\stackrel{A Z}{A Z}$ & $\begin{array}{l}+21 \\
+21\end{array}$ & $\begin{array}{r}10 \\
0\end{array}$ & $\begin{array}{l}\text { Red } 4 \\
\text { Red } 13\end{array}$ & $\begin{array}{l}\text { Quartz } \\
\text { Quartz }\end{array}$ & $\begin{array}{l}51.6 \\
24.3\end{array}$ & $\begin{array}{l}56.2 \\
26.5\end{array}$ \\
\hline & $\begin{array}{l}2,990 \\
2,990\end{array}$ & $\begin{array}{l}45 \\
15\end{array}$ & $\begin{array}{l}\text { GR } \\
\text { GR }\end{array}$ & $\begin{array}{l}-50 \\
-50\end{array}$ & $\begin{array}{l}50 \\
50\end{array}$ & $\begin{array}{l}\text { Black } 3 \\
\text { Black } 4\end{array}$ & Quartz & $\begin{array}{l}\text { Bad I } \\
0.15\end{array}$ & 0.16 \\
\hline \multirow[t]{4}{*}{$7-208$} & $\begin{array}{l}5,890 \\
5,920\end{array}$ & $\begin{array}{l}45 \\
45\end{array}$ & $\begin{array}{l}A Z \\
A Z\end{array}$ & $\begin{array}{l}+11 \\
+11\end{array}$ & $\begin{array}{r}50 \\
0\end{array}$ & $\begin{array}{l}\text { Black } \underset{6}{\text { Black } 2}\end{array}$ & $\begin{array}{l}\text { Quartz } \\
\text { Quartz }\end{array}$ & $\begin{array}{l}15.5 \\
14.0\end{array}$ & $\begin{array}{l}16.9 \\
15.2\end{array}$ \\
\hline & 5,910 & 30 & $A Z$ & +11 & 10 & Black 7 & Quartz & 15.0 & 16.3 \\
\hline & 5,920 & 7.5 & $A Z$ & +11 & 0 & Black 1 & Quartz & 5.6 & 6.1 \\
\hline & 5,890 & 45 & GR & -50 & $50^{\prime}$ & Black 5 & Quartz & 0.8 & 0.9 \\
\hline \multirow[t]{2}{*}{$7-210$} & $\begin{array}{l}8,900 \\
8,900\end{array}$ & $\begin{array}{l}45 \\
45\end{array}$ & $\begin{array}{l}A Z \\
A Z\end{array}$ & $\begin{array}{l}+7 \\
+7\end{array}$ & $\begin{array}{l}10 \\
10\end{array}$ & $\begin{array}{c}\text { White } 1 \\
\text { White } 3 \\
\text { White } 4(\mathrm{~d})\end{array}$ & $\begin{array}{c}\text { Quartz } \\
\text { Quartz } \\
0-52\end{array}$ & $\begin{array}{l}6.3 \\
0.61\end{array}$ & $\begin{array}{l}6.8 \\
0.67\end{array}$ \\
\hline & $\begin{array}{l}8,900 \\
8,900 \\
8,900 \\
8,900\end{array}$ & $\begin{array}{l}45 \\
45 \\
45 \\
45\end{array}$ & $\begin{array}{l}A Z \\
A Z Z \\
A Z Z \\
A Z\end{array}$ & $\begin{array}{l}+7 \\
+7 \\
+7 \\
+7\end{array}$ & $\begin{array}{l}10 \\
10 \\
10 \\
10\end{array}$ & $\begin{array}{l}\text { Grey } 7 \\
\text { Grey } 8 \\
\text { Brass } 3 \\
\text { Brass } 8\end{array}$ & $\begin{array}{r}3-69 \\
2-58 \\
\text { Spec. } \\
7-56\end{array}$ & $\begin{array}{l}4.3 \\
3.3 \\
2.1 \\
1.5\end{array}$ & $\begin{array}{l}4.8 \\
3.8 \\
2.9 \\
1.7\end{array}$ \\
\hline \multirow[t]{2}{*}{ USFS } & $\begin{array}{l}18,000 \\
18,000\end{array}$ & $\begin{array}{l}30 \\
30\end{array}$ & $\begin{array}{l}A Z \\
A Z\end{array}$ & $\begin{array}{l}+3.5 \\
+3.5\end{array}$ & $\begin{array}{l}3 \\
3\end{array}$ & $\begin{array}{l}\text { Grey } 12 \\
\text { Brass } 1\end{array}$ & $\begin{array}{l}\text { Quartz } \\
\text { Quartz }\end{array}$ & $\begin{array}{l}1.4 \\
1.4\end{array}$ & $\begin{array}{l}1.5 \\
1.5\end{array}$ \\
\hline & 18,000 & 30 & $\mathbf{A Z}$ & +3.5 & 3 & Grey $6+13$ & Quartz & -- & $-\cdots$ \\
\hline
\end{tabular}

(a) $\mathrm{AZ}=$ Calorimeter aligned toward air zero. GR = Calorimeter aligned to measure radiation reflected from the ground in front of station.

(b) Not corrected for atmospheric attenuation.

(c) Total energy received up to arrival of shock wave, at 0.58 sec.

(d) Calorimeters connected in series but with opposite polarity.

These tables list only the results of measurements made by USNRDL personnel along the blast line. Results of the measurements made in cooperation with Project 3.1 personnel, in connection with the thermal damage to parked aircraft, are given in Appendix A. Results of the measurements made in cooperation with the 4925th Air Bombardment Group, in connection with the thermal energy incident upon the drop aircraft, are given in Appendix B.

\subsection{RADTOMETERS}

The original Heiland records were read with the Universal Telereader. 52 


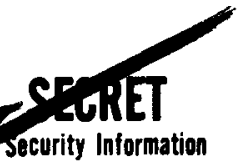

An intensity-vs-time curve was plotted for each radiometer, and in the case of the foil radiometers, was integrated to obtain the total energy. No integration was carried out for the flne-wire radiometer curres because these instruments were not calibrated.

The total energy values were obtained by integration of the intensityrs-time curves from 0 to 2 sec. The 2-sec interval was chosen because at the end of $2 \mathrm{sec}$, for the weapons of the size concerned, the intensity has decreased to a small fraction of the peak intensity, and carrying the integration to longer times increases the uncertainties in the reduction of data, but adds little information of importance.

The radiometer results are listed in Table 4.5. Column 7 of the table gives the maximum intensities, and column 8 the total energies received in the time interval from 0 to $2 \mathrm{sec}$. For comparison purposes, similar data are given in columns 9 and 10 for the calorimeters at the same locations. In general, the agreement between the calorimeter and radiometer results is quite good, and in only one case did the values differ by more than the experimental error of the radiometers, which is about 15 per cent.

TABLE 4.5

Disk Radiometer Results(a)

\begin{tabular}{|c|c|c|c|c|c|c|c|c|c|}
\hline Shot & Station & $\begin{array}{c}\text { Height } \\
\text { (ft) }\end{array}$ & Filter & $\begin{array}{c}\text { Half- } \\
\text { angle } \\
\text { of Field } \\
\text { of View } \\
\text { (deg) }\end{array}$ & $\begin{array}{c}\text { Instrument } \\
\text { Type }\end{array}$ & $\begin{array}{c}\text { Maximum } \\
\text { Intensity, } \\
\text { Radiometers } \\
\text { (cal/sq cm/ } / \mathrm{sec} \text { ) }\end{array}$ & \begin{tabular}{|c|} 
Total \\
Energy to \\
2.0 sec, \\
Radiometers \\
$(\mathrm{cal} / \mathrm{sq} \mathrm{cm})$
\end{tabular} & $\begin{array}{c}\text { Maximum } \\
\text { Intensity, } \\
\text { Calorimeters } \\
\text { (cal/sq cm/sec) }\end{array}$ & \begin{tabular}{|c|}
\multicolumn{1}{|c|}{ Total } \\
Energy to \\
2.0 sec, \\
Caiorimeters \\
(cal/sq cm)
\end{tabular} \\
\hline 1 & F-208 & 10 & Quartz & 45 & $\mathbf{K}$ & \begin{tabular}{|c|}
20 \\
\end{tabular} & 8.0 & 22 & 8.0 \\
\hline 2 & $\begin{array}{l}7-204 \\
7-204 \\
\end{array}$ & \begin{tabular}{l|}
10 \\
10 \\
\end{tabular} & $\begin{array}{l}\text { Quartz } \\
\text { Quartz }\end{array}$ & $\begin{array}{l}45 \\
45\end{array}$ & $\underset{\text { MIT }}{\mathrm{K}}$ & $\begin{array}{l}11 \\
10\end{array}$ & $\begin{array}{l}4.4 \\
3.5\end{array}$ & $\begin{array}{l}10 \\
10\end{array}$ & $\begin{array}{l}3.9 \\
3.9\end{array}$ \\
\hline 3 & $\begin{array}{l}7-202 \\
7-202 \\
7-204 \\
\text { USFS } \\
\text { USFS } \\
\end{array}$ & \begin{tabular}{r|}
3 \\
3 \\
10 \\
3 \\
3 \\
\end{tabular} & \begin{tabular}{|c|}
$2-58$ \\
$2-58$ \\
Quartz \\
Quartz \\
Quartz
\end{tabular} & $\begin{array}{l}45 \\
45 \\
45 \\
24 \\
24 \\
\end{array}$ & $\begin{array}{c}\mathbf{K} \\
\mathbf{K} \\
\mathbf{K} \\
\mathbf{K} \\
\mathbf{M} \mathbf{T} \\
\end{array}$ & $\begin{array}{l}33 \\
\\
5.4 \\
4.7 \\
\end{array}$ & \begin{tabular}{|r|r|}
\multicolumn{2}{|c|}{25} \\
irn out \\
if scale \\
2.0 \\
1.6
\end{tabular} & $\begin{array}{c}- \\
\overline{79} \\
4.3 \\
4.3\end{array}$ & $\begin{array}{l}\cdots-(b) \\
31 \\
1.7 \\
1.7\end{array}$ \\
\hline 4 & $\begin{array}{l}7-204 \\
\text { USFS } \\
\text { USFS }\end{array}$ & \begin{tabular}{r|}
10 \\
3 \\
3
\end{tabular} & $\begin{array}{l}\text { Quartz } \\
\text { Quartz } \\
\text { Quartz }\end{array}$ & $\begin{array}{l}45 \\
24 \\
24\end{array}$ & $\begin{array}{c}\mathbf{K} \\
\mathbf{M} \\
\mathrm{MIT}\end{array}$ & $\begin{array}{l}3.9 \\
3.6\end{array}$ & $\begin{array}{r}\text { out } \\
1.4 \\
1.2\end{array}$ & $\begin{array}{r}120 \\
3.8 \\
3.8\end{array}$ & $\begin{array}{l}48 \\
1.2 \\
1.2\end{array}$ \\
\hline
\end{tabular}

(a) Not corrected for filter or atmospheric attenuation.

(b) No energy values given for calorimeter because presence of serious dust obscurations at this station would make any comparison of little value.

4.4 PASSIVE RECEIVERS

The panels of metal foils recovered after the shots were returned to the Laboratory, and a careful assessment made of the damage produced to each foil. In all cases, the panels were read independently by three observers. Fach observer recorded the thicknesses of metal which bracketed the chosen effect, and, from the degree of melt of the thinner of the two, estimated and recorded that thickness which rould have show the
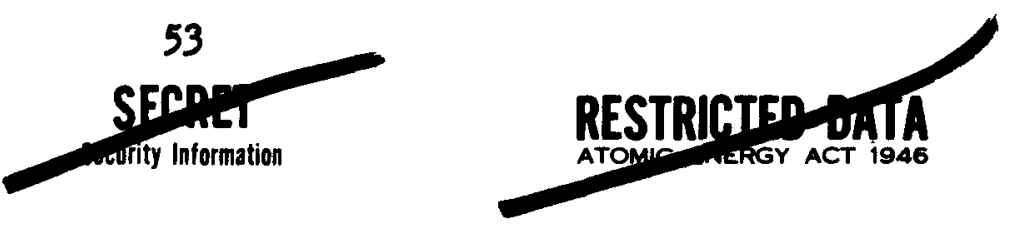


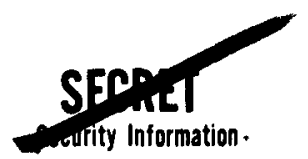

threshold criterion. The mean value for each indicator was then determined from the three thickness estimates.

The field pulse time was obtained from the calorimetry data by approximating the rise and fall portions of the field pulse with straight lines, without changing the total energy or the peak intensity, and reading the time between the two abscissa intercepts. The energies were then obtained directly from the foil calibration curves. Tables 4.6, 4.7, 4.8, and 4.9 give results of the passive-receiver panels. In these tables column 8 is the energy received under the filter and 9 is the total energy received at the station. This value is obtained by correcting column 7 for the peak transmission of the two filters used (Corning No, 0-52 and 9-54). In addition a correction of approximately 10 per cent was added to the energy values obtained by the foils under the $0-52$ filters for the energy lost below $0.36 \mu$, which is the lower wave length cut-off of the filter.

TABLE 4.6

Passive-receiver Results, Shot 1

\begin{tabular}{|c|c|c|c|c|c|c|c|c|}
\hline \multirow[b]{2}{*}{ Station } & \multirow{2}{*}{$\begin{array}{l}\text { Slant } \\
\text { Distance } \\
\text { (ft) }\end{array}$} & \multirow{2}{*}{$\begin{array}{l}\text { Height } \\
\text { above } \\
\text { Grade } \\
\text { (ft) }\end{array}$} & \multirow{2}{*}{$\begin{array}{c}\text { Angle from } \\
\text { Horizontal } \\
\text { (deg) }\end{array}$} & \multirow[b]{2}{*}{ Metal } & \multicolumn{3}{|c|}{$\begin{array}{l}\text { Indicated Total Energies } \\
(\mathrm{cal} / \mathrm{sq} \mathrm{cm})\end{array}$} & \multirow{2}{*}{$\begin{array}{c}\text { Energy at } \\
\text { Station } \\
\text { (cal/sq cm) }\end{array}$} \\
\hline & & & & & Bracketing & Estimated & $\begin{array}{c}\text { Mean } \\
\text { Estimated }\end{array}$ & \\
\hline \multicolumn{9}{|c|}{ Alignment: Facing Air Zero(a) } \\
\hline $200^{\circ}$ & 802 & 2 & 90 & $\begin{array}{l}\mathrm{Ag} \\
\mathrm{Cu} \\
\mathrm{Ag}(\mathrm{b})\end{array}$ & $\begin{array}{l}38.2-45.4 \\
34.5-44.4 \\
33.0-62.4\end{array}$ & $\begin{array}{l}41.9 \\
41.9 \\
46.1\end{array}$ & 43.3 & 47.1 \\
\hline 202 & 940 & 50 & 56 & $\begin{array}{l}\mathrm{Ag} \\
\mathrm{Cd} \\
\mathrm{Pb}\end{array}$ & $\begin{array}{l}33.2-45.4 \\
24.0-31.1 \\
51.6-\ldots\end{array}$ & $\begin{array}{l}38.2 \\
28.4 \\
57.2\end{array}$ & 41.3 & 44.9 \\
\hline 202 & 970 & 10 & 58 & $\begin{array}{l}\mathrm{Ag} \\
\mathrm{Cd} \\
\mathrm{Pb}\end{array}$ & $\begin{array}{l}33.2-45.4 \\
24.0-31.1 \\
51.6-\ldots\end{array}$ & $\begin{array}{l}38.2 \\
28.8 \\
51.6\end{array}$ & 39.5 & 42.9 \\
\hline 202 & 980 & 2 & 58 & $\begin{array}{l}\mathrm{Ag} \\
\mathrm{Cd} \\
\mathrm{Pb}\end{array}$ & $\begin{array}{l}13.8-80.1 \\
18.7-31.1 \\
31.9-51.6\end{array}$ & $\begin{array}{l}56.2 \\
27.2 \\
46.5\end{array}$ & 43.3 & $47.1(\mathrm{c})$ \\
\hline 204 & 1,340 & 2 & 39 & $\begin{array}{l}\mathrm{Cd} \\
\mathrm{Sn} \\
\mathrm{Pb}\end{array}$ & $\begin{array}{l}14.6-18.3 \\
24.1-30.2 \\
18.9-24.2\end{array}$ & $\begin{array}{l}14.9 \\
28.3 \\
19.7\end{array}$ & 21.0 & 22.8 \\
\hline 206 & 1,760 & 2 & 28 & $\begin{array}{l}\mathrm{Cd} \\
\mathrm{Sn} \\
\mathrm{Pb}\end{array}$ & $\begin{array}{l}10.2-12.3 \\
13.3- \\
11.2-14.6\end{array}$ & $\begin{array}{l}10.4 \\
13.2 \\
12.1\end{array}$ & 11.9 & 12.9 \\
\hline 208 & 2,200 & 50 & 21 & $\begin{array}{l}\mathrm{Cd} \\
\mathrm{Sn} \\
\mathrm{Pb}\end{array}$ & $\begin{array}{l}7.3-9.0 \\
6.9-9.3 \\
6.3-8.5\end{array}$ & $\begin{array}{l}7.4 \\
8.7 \\
6.3\end{array}$ & 7.5 & 8.1 \\
\hline 208 & 2,210 & 10 & 22 & $\begin{array}{l}\mathrm{Cd} \\
\mathrm{Sn} \\
\mathrm{Pb}\end{array}$ & $\begin{array}{l}5.9-7.3 \\
6.9-9.3 \\
6.3-8.5\end{array}$ & $\begin{array}{l}5.9 \\
8.3 \\
6.7\end{array}$ & 7.0 & 7.6 \\
\hline 208 & 2,220 & 2 & 22 & $\begin{array}{l}\mathrm{Cd} \\
\mathrm{Sn} \\
\mathrm{Pb}\end{array}$ & $\begin{array}{l}5.9-7.3 \\
6.9-9.3 \\
6.3-8.5\end{array}$ & $\begin{array}{l}5.9 \\
8.7 \\
6.3\end{array}$ & 7.0 & 7.6 \\
\hline
\end{tabular}





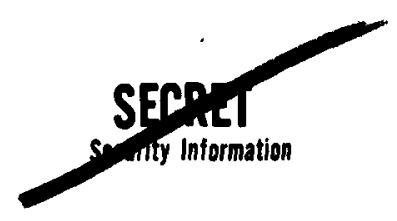

TABLE 4.7

Passive-receiver Results Shot 2

\begin{tabular}{|c|c|c|c|c|c|c|c|c|}
\hline \multirow[b]{2}{*}{ Station } & \multirow{2}{*}{$\begin{array}{c}\text { Slant } \\
\text { Distance } \\
\text { (ft) }\end{array}$} & \multirow{2}{*}{$\begin{array}{c}\text { Height } \\
\text { a bove } \\
\text { Grade } \\
\text { (ft) }\end{array}$} & \multirow{2}{*}{$\begin{array}{c}\text { Angle from } \\
\text { Horizontal } \\
\text { (deg) }\end{array}$} & \multirow[b]{2}{*}{ Metal } & \multicolumn{3}{|c|}{$\begin{array}{l}\text { Indicated Total Energies } \\
(\text { (cal } / \mathrm{sq} \mathrm{cm})\end{array}$} & \multirow{2}{*}{$\begin{array}{c}\text { Energy at } \\
\text { Station } \\
\text { (cal/sq cm) }\end{array}$} \\
\hline & & & & & Bracketing & Estimated & $\begin{array}{c}\text { Mean } \\
\text { Estimated }\end{array}$ & \\
\hline \multicolumn{9}{|c|}{ Alignment: Facing Air Zero(a) } \\
\hline 200 & 1,120 & 2 & 90 & $\begin{array}{l}\mathrm{Cd} \\
\mathrm{Sn} \\
\mathrm{Pb}\end{array}$ & $\begin{array}{l}23.9-32.5 \\
30.2-44.0 \\
31.9-\ldots\end{array}$ & $\begin{array}{l}24.4 \\
31.0 \\
35.2\end{array}$ & 30.2 & 36.1 \\
\hline 201 & 1,280 & 2 & 58 & $\begin{array}{l}\mathrm{Cd} \\
\mathrm{Sn} \\
\mathrm{Pb}\end{array}$ & $\begin{array}{l}18.3-18.7 \\
24.1--. \\
18.8-24.2\end{array}$ & $\begin{array}{l}18.7 \\
24.1 \\
19.6\end{array}$ & 20.8 & 24.9 \\
\hline 202 & 1,770 & 2 & 36 & $\begin{array}{l}\mathrm{Cd} \\
\mathrm{Sn} \\
\mathrm{Pb}\end{array}$ & $\begin{array}{c}9.0-10.3 \\
11.2--. .- \\
11.2-12.0\end{array}$ & $\begin{array}{r}9.0 \\
13.8 \\
11.2\end{array}$ & 11.3 & 13.5 \\
\hline 204 & 3,080 & 2 & 20 & $\begin{array}{l}\mathrm{Cd} \\
\mathrm{Sn} \\
\mathrm{Pb}\end{array}$ & $\begin{array}{l}2.0 \ldots \ldots \\
2.6 \cdots \cdots \\
2.7 \ldots \ldots\end{array}$ & $\begin{array}{l}3.0 \\
3.8 \\
3.8\end{array}$ & 3.5 & 4.2 \\
\hline 206 & 4,510 & 2 & 14 & $\begin{array}{l}\mathrm{Cd} \\
\mathrm{Sn} \\
\mathrm{Pb} \\
\mathrm{Cd}(\mathrm{b}) \\
\mathrm{Sn}(\mathrm{b}) \\
\mathrm{Pb}(\mathrm{b})\end{array}$ & $\begin{array}{l}1.2-1.5 \\
1.3-2.0 \\
1.1-1.8 \\
1.0-1.3 \\
0.9-1.3 \\
1.1-1.7\end{array}$ & $\begin{array}{l}1.3 \\
1.7 \\
1.1 \\
1.1 \\
1.1 \\
1.6\end{array}$ & 1.4 & 1.7 \\
\hline
\end{tabular}

(a) Aligned facing the expected (not the actual) point of detonation.

(b) Three-legged disk geometry.

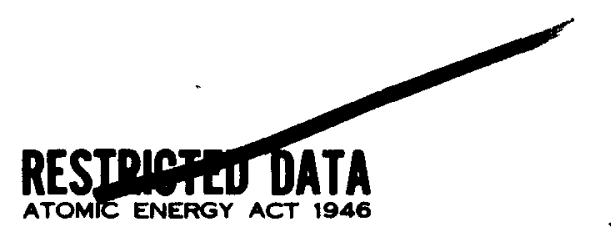


TABTE 4.8

Passive-receiver Resnlts, Shot 3

\begin{tabular}{|c|c|c|c|c|c|c|c|c|}
\hline \multirow[b]{2}{*}{ Station } & \multirow{2}{*}{$\begin{array}{c}\text { Slant } \\
\text { Distance } \\
\text { (ft) }\end{array}$} & \multirow{2}{*}{$\begin{array}{c}\text { Height } \\
\text { above } \\
\text { Grade } \\
\text { (ft) }\end{array}$} & \multirow{2}{*}{$\begin{array}{l}\text { Angle from } \\
\text { Horizontal } \\
\text { (deg) }\end{array}$} & \multirow[b]{2}{*}{ Metal } & \multicolumn{3}{|c|}{$\begin{array}{l}\text { Indicated Total Energies } \\
(\mathrm{cal} / \mathrm{sq} \mathbf{~ c m})\end{array}$} & \multirow{2}{*}{$\begin{array}{l}\text { Energy at } \\
\text { Station } \\
(\mathrm{cal} / \mathrm{sq} \mathrm{cm})\end{array}$} \\
\hline & & & & & Bracketing & Estimated & $\begin{array}{c}\text { Mean } \\
\text { Estimated }\end{array}$ & \\
\hline \multicolumn{9}{|c|}{ Alignment: Facing, Air Zern(a) } \\
\hline 202 & 3,450 & 2 & 90 & $\begin{array}{l}A g \\
C u \\
\Delta g(b)\end{array}$ & $\begin{array}{r}48.9-65.0 \\
47.0-49.3 \\
44.8-86.2\end{array}$ & $\begin{array}{l}54.3 \\
48.1 \\
46.6\end{array}$ & 49.7 & 59.4 \\
\hline 202 & 3,450 & 2 & 66 & $\begin{array}{l}A g \\
C u \\
A g(b)\end{array}$ & $\begin{array}{l}34.4-48.9 \\
38.4-47.0 \\
34.2-63.8\end{array}$ & $\begin{array}{l}44.8 \\
42.9 \\
49.6\end{array}$ & 45.8 & 54.8 \\
\hline 204 & 4,470 & 50 & 47 & $\begin{array}{l}\mathrm{Ag} \\
\mathrm{Cd} \\
\mathrm{Pb}\end{array}$ & $\begin{array}{l}26.9-28.2 \\
19.8-25.0 \\
25.2-28.2\end{array}$ & $\begin{array}{l}27.7 \\
24.3 \\
26.0\end{array}$ & 26.0 & 28.3 \\
\hline 204 & 4,500 & 10 & 47 & $\begin{array}{l}\mathrm{Ag} \\
\mathrm{Cd} \\
\mathrm{Pb}\end{array}$ & $\begin{array}{l}26.9-28.2 \\
19.8-25.0 \\
25.2-28.2\end{array}$ & $\begin{array}{l}27.9 \\
21.6 \\
27.4\end{array}$ & 25.6 & 27.8 \\
\hline 204 & 4,510 & 2 & 48 & $\begin{array}{l}\mathrm{Ag} \\
\mathrm{Cb}\end{array}$ & $\begin{array}{l}26.9-28.2 \\
19.8-25.0 \\
19.8-25.2\end{array}$ & $\begin{array}{l}27.7 \\
22.1 \\
22.7\end{array}$ & 24.2 & 26.3 \\
\hline 206 & 5,590 & 2 & 36 & $\begin{array}{l}\mathrm{Cd} \\
\mathrm{Sn}\end{array}$ & $\begin{array}{l}12.9-15.3 \\
14.6-19.7 \\
15.1-17.9\end{array}$ & $\begin{array}{l}14.7 \\
15.9 \\
15.9\end{array}$ & 15.5 & 18.5 \\
\hline 208 & 6,810 & 50 & 29 & $\begin{array}{l}\mathbf{C d} \\
\mathbf{S n} \\
\mathbf{P b}\end{array}$ & $\begin{array}{r}9.5-13.4 \\
11.1-15.1\end{array}$ & $\begin{array}{r}9.0 \\
11.6 \\
11.1\end{array}$ & 10.6 & 11.5 \\
\hline 208 & 6,830 & 10 & 29 & $\begin{array}{l}\mathrm{Cd} \\
\mathrm{Sn} \\
\mathrm{Pb}\end{array}$ & $\begin{array}{r}9.5-10.8 \\
13.4-13.7 \\
11.1-15.1\end{array}$ & $\begin{array}{r}8.5 \\
13.4 \\
11.5\end{array}$ & 11.5 & 12.5 \\
\hline 208 & 6,830 & $\mathbf{2}$ & 29 & $\begin{array}{l}\mathrm{Cd} \\
\mathrm{Sn} \\
\mathrm{Pb}\end{array}$ & $\begin{array}{r}9.5-13.4 \\
11.1-15.1\end{array}$ & $\begin{array}{r}9.0 \\
11.5 \\
11.2\end{array}$ & 10.6 & 11.5 \\
\hline 210 & 9,540 & 2 & 20 & $\begin{array}{l}\mathrm{Cd} \\
\mathbf{8 n} \\
\mathbf{P b}\end{array}$ & $\begin{array}{l}5.3-7.4 \\
5.6-8.1 \\
6.3-6.7\end{array}$ & $\begin{array}{l}6.4 \\
7.2 \\
6.5\end{array}$ & 6.7 & 7.3 \\
\hline 11,000 & 11,500 & 3 & 17 & $\begin{array}{l}\text { Cd } \\
\mathrm{Sn} \\
\mathrm{Pb}\end{array}$ & $\begin{array}{l}3.4-4.5 \\
4.1-5.6 \\
4.0-6.0\end{array}$ & $\begin{array}{l}3.4 \\
4.1 \\
4.9\end{array}$ & 4.1 & 4.9 \\
\hline 12,000 & 12,400 & 3 & 15 & $\begin{array}{l}\mathrm{Cd} \\
\mathrm{Sn} \\
\mathrm{Pb}\end{array}$ & $\begin{array}{l}2.9-3.4 \\
3.0-4.1 \\
4.0-5.2\end{array}$ & $\begin{array}{l}3.2 \\
3.0 \\
4.0\end{array}$ & 3.4 & 4.1 \\
\hline 13,000 & 13,400 & $\mathbf{3}$ & 14 & $\begin{array}{l}\mathrm{Cd} \\
\mathrm{Sn} \\
\mathrm{Pb}\end{array}$ & $\begin{array}{l}2.9-3.4 \\
2.5-3.0 \\
3.7-4.0\end{array}$ & $\begin{array}{l}3.0 \\
2.6 \\
3.9\end{array}$ & 3.2 & 3.8 \\
\hline 16,000 & 16,300 & 3 & 12 & $\begin{array}{l}\mathrm{Cd} \\
\mathrm{gn} \\
\mathrm{Pb}\end{array}$ & $\begin{array}{l}1.6-2.2 \\
1.5-2.5 \\
2.7-3.7\end{array}$ & $\begin{array}{l}2.0 \\
2.1 \\
2.7 \\
\end{array}$ & 2.3 & 2.8 \\
\hline
\end{tabular}


TABLE 4.8 (Contimed)

Passive-receiver Results, Shot 3

\begin{tabular}{|c|c|c|c|c|c|c|c|c|}
\hline \multirow[b]{2}{*}{ Station } & \multirow{2}{*}{$\begin{array}{c}\text { Slant } \\
\text { Distance } \\
\text { (ft) }\end{array}$} & \multirow{2}{*}{$\begin{array}{l}\text { Height } \\
\text { above } \\
\text { Grade } \\
\text { (ft) }\end{array}$} & \multirow{2}{*}{$\begin{array}{l}\text { Angle from } \\
\text { Horizontal } \\
\text { (deg) }\end{array}$} & \multirow[b]{2}{*}{ Metal } & \multicolumn{3}{|c|}{$\begin{array}{l}\text { Indicated Total Energies } \\
\text { (cal } / \mathrm{sq} \mathrm{cm} \text { ) }\end{array}$} & \multirow{2}{*}{$\begin{array}{c}\text { Energy at } \\
\text { Station } \\
\text { (cal/sq cm) }\end{array}$} \\
\hline & & & & & Bracketing & Estimated & $\begin{array}{c}\text { Mean } \\
\text { Estimated }\end{array}$ & \\
\hline 18,000 & 18,300 & 3 & 10 & $\begin{array}{l}\mathrm{Cd} \\
\mathrm{Sn} \\
\mathrm{Pb}\end{array}$ & $\begin{array}{l}1.1-1.6 \\
1.5-2.5 \\
2.0-2.7\end{array}$ & $\begin{array}{l}1.3 \\
1.5 \\
2.0\end{array}$ & 1.6 & 1.9 \\
\hline 18,000 & 18,300 & 3 & 10 & $\begin{array}{l}\mathrm{Cd} \\
\mathrm{Sn} \\
\mathrm{Pb}\end{array}$ & $\begin{array}{l}1.1-1.6 \\
1.5-2.5 \\
2.0-2.1\end{array}$ & $\begin{array}{l}1.2 \\
2.2 \\
2.0\end{array}$ & 1.8 & 2.2 \\
\hline 20,000 & 20,200 & 3 & 9 & $\begin{array}{l}\mathrm{Cd} \\
\mathrm{Sn} \\
\mathrm{Pb} \\
\mathrm{Cd}(\mathrm{c}) \\
\mathrm{Sn}(\mathrm{c}) \\
\mathrm{Pb}(\mathrm{c})\end{array}$ & $\begin{array}{l}0.9-1.1 \\
-\cdots-1.1 \\
-1.6-1.3 \\
1.0-1.4 \\
1.1-1.4\end{array}$ & $\begin{array}{l}1.1 \\
0.8 \\
0.8 \\
1.7 \\
1.3 \\
1.2 \\
\end{array}$ & 0.9 & 1.4 \\
\hline $\begin{array}{l}\text { Special } \\
18,000\end{array}$ & $\begin{array}{l}\text { panel) } \\
18,300\end{array}$ & 3 & 10 & $\begin{array}{l}\mathrm{Cd}(\mathrm{c}) \\
\mathrm{Sn}(\mathrm{c}) \\
\mathrm{Pb}(\mathrm{c})\end{array}$ & $\begin{array}{l}1.9-2.3 \\
1.0-1.4 \\
1.7-2.0\end{array}$ & $\begin{array}{l}2.2 \\
1.1 \\
1.8\end{array}$ & 1.7 & 1.8 \\
\hline Alignme & nt: $\underset{4,470}{\text { Ground }}$ & $\begin{array}{l}\text { Reflectio } \\
50\end{array}$ & $\begin{array}{ll}\text { (d) } & \\
& -47\end{array}$ & $\begin{array}{l}\mathrm{Cd} \\
\mathrm{Sn} \\
\mathrm{Pb}\end{array}$ & \begin{tabular}{ll}
$-\cdots$ & 5.9 \\
\hdashline- & 5.4 \\
$-\cdots$ & 6.5
\end{tabular} & $\begin{array}{l}--- \\
\cdots- \\
--\end{array}$ & --- & 6 \\
\hline 208 & 6,810 & 50 & -45 & $\begin{array}{l}\mathrm{Cd} \\
\mathrm{Sn} \\
\mathrm{YD} \\
\end{array}$ & \begin{tabular}{ll}
$\ldots-$ & 3.4 \\
\hdashline- & 2.5 \\
\hdashline$-\cdots$ & 3.7 \\
\end{tabular} & $\begin{array}{l}3.1 \\
1.5 \\
2.5 \\
\end{array}$ & 2.4 & 2.6 \\
\hline \multicolumn{4}{|c|}{ Alignment: Panel Vertical(e) } & & & & & \\
\hline 204 & 6,830 & 2 & 0 & $\begin{array}{l}\mathrm{Ag} \\
\mathrm{Cd} \\
\mathrm{Pb}\end{array}$ & $\begin{array}{l}15.3-26.0 \\
12.9-15.3 \\
12.1-15.1\end{array}$ & $\begin{array}{l}19.4 \\
14.9 \\
13.9\end{array}$ & 16.1 & 17.5 \\
\hline 208 & 6,830 & 2 & 0 & $\begin{array}{l}\mathrm{Cd} \\
\mathrm{Sn} \\
\mathrm{Pb}\end{array}$ & $\begin{array}{r}-9.5 \\
9.5-13.4 \\
7.8-11.1 \\
\end{array}$ & $\begin{array}{l}9.0 \\
9.5 \\
8.8 \\
\end{array}$ & 9.1 & 9.9 \\
\hline \multicolumn{4}{|c|}{ Alignment: Panel Horizontal(t) } & & & & & \\
\hline 204 & 4,510 & 2 & 90 & $\begin{array}{l}\mathrm{Ag} \\
\mathrm{Cd} \\
\mathrm{Pb}\end{array}$ & $\begin{array}{l}26.0-26.9 \\
---12.9 \\
---12.1\end{array}$ & $\begin{array}{l}26.4(\mathrm{~g}) \\
11.5 \\
10.3\end{array}$ & 10.9 & 11.8 \\
\hline 208 & 6,830 & 2 & 90 & $\begin{array}{l}\mathrm{Cd} \\
\mathrm{Sn} \\
\mathrm{Pb}\end{array}$ & $\begin{array}{l}5.3-6.6 \\
2.5-3.0 \\
4.0-6.0\end{array}$ & $\begin{array}{l}5.4 \\
2.9 \\
5.2 \\
\end{array}$ & 4.5 & 4.9 \\
\hline
\end{tabular}

(a) Aligned facing the expected (not the actual) point of detonation.

(b) Strip geometry.

(c) Three-legged disk geometry.

(d) 17 igned to measure radiation reflected from earth in front of station at specular angle.

(e) Aligned to measure radiation as received by a vertical surface.

(f) Aligned to measure radiation as received by a horizontal surface.

(8) Roinforced br radiation reflected from aluminum faceplate and was not included in calculating total energy. 
TABLE 4.9

Passive-receiver Results, Shot 4

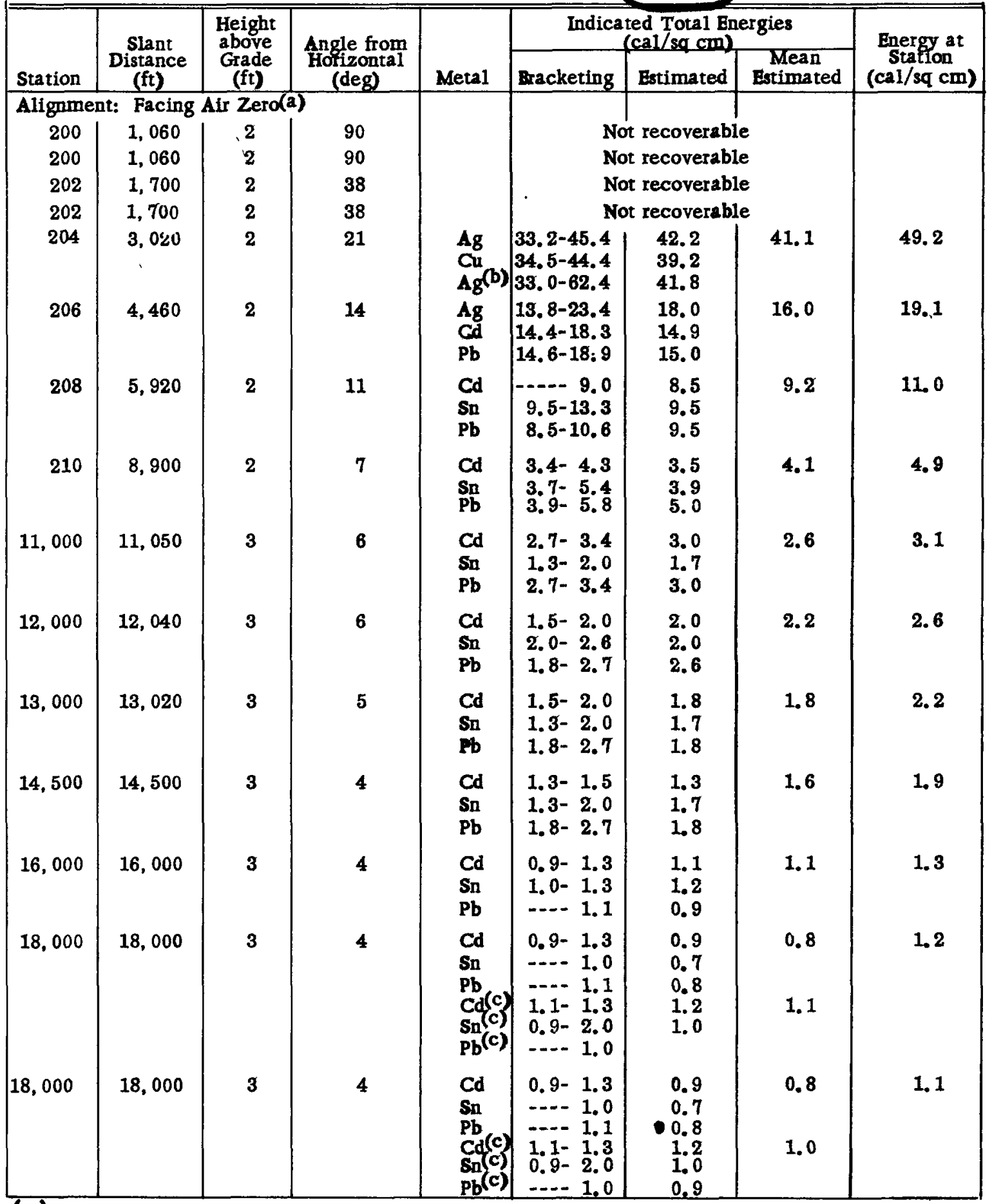

(a) Aligned facing the expected (not the actual) point of detonation.

(b) Strip geometry.

Three-legged disk geometry. 


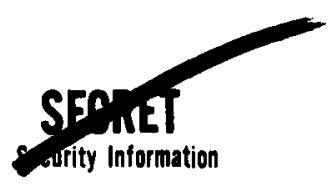

\subsection{SPHERE CALORIMETERS}

Unfortunately, no usable data were obtained from the sphere calorimeters. The results obtained were widely scattered and differed from the other measurements by as much as an order of magnitude. The biggest difficulty with these instruments seemed to be in the adjustment of the brake attached to the dial indicator. If this brake is made too loose, severe deflections are produced by the shock wave and if too tight, the indicator moves in spurts and low results are obtained. 


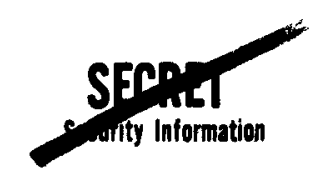

CHAPTER 5

\section{DISCUSSION OF RESULTS}

\subsection{CALORTMETERS}

Generally speaking, the data obtained during these operations were about as expected. The total energy data obtained from the calorimeters curing the four shots are shown in station-to-station comparisons in Figs. 5.1 through 5.4. The energy values represented as points in these figures were taken from column 10, Tables 4.1 through 4.4, and corrected for atmospheric attemation, taking a transmission of 96 per cent per mile ror shots 1 and 2 and 95 per cent per mile for shots 3 and $b$ only the Uation those calorineters which had the full fleld of vien, unobscured by dust, were used for these plots. The lines have been drawn on the basis of the calorimeter data, but with the theoretical (inverse-square) slope.

The atmospheric transmission coefficients used were obtained by the Naval Research Laboratory (NRL) I]. They were specified for collimated or narrow beam conditions, and are therefore not strictly applicable to the wide-field-of-viow calorimeters. According to $\mathrm{E} .0$. Hulbert $8 /$ "the effect of field of view of the receiver upon the energy received through the atmosphere from a point source at a distance is expressed by

$$
R_{A}=R_{c}+g\left(1-R_{c}\right) \perp(A)
$$

when $R_{c}$ is the energy received by a receiver of very small (zero) field of view. $R_{c}$ is calculated from the atmospheric attemation coefficient for collimated light ...... $\mathrm{R}_{A}$ is the energy received by the same receiver with circular field of view A radians in diameter, wth axis pointing at the source. $g$ depends on the reflectivity of the surface and $f(A)$ on the polar diagram of scattering. From experiments with a source and a receiver on the surface of average rellectivity, for wave lengths 3600 to $6200 \AA$, for $\nabla$ (Visibility) about 5 to $50 \mathrm{~km}$, and for 45 to $25^{\circ}, \mathrm{gf}(\mathrm{A})$ was found to be $0.5\left(1-e^{-A}\right)$. Then Equation 5.1 becones

$$
\mathrm{R}_{\mathrm{A}}=\mathrm{R}_{\mathrm{c}}+0.5\left(1-\mathrm{R}_{\mathrm{c}}\right)\left(1-0^{-\mathrm{A}}\right) . \mathrm{n}
$$

Equation 5.2 shows that use of the collimated transmission values for correcting data obtained with the wide field of vien of these instruments will result in an orer-correction. Calculations on the amount of overcorrection, for the data obtained, using Equation 5.2 show that in the worst case (greatest slant range) the over-correction amounts to about 


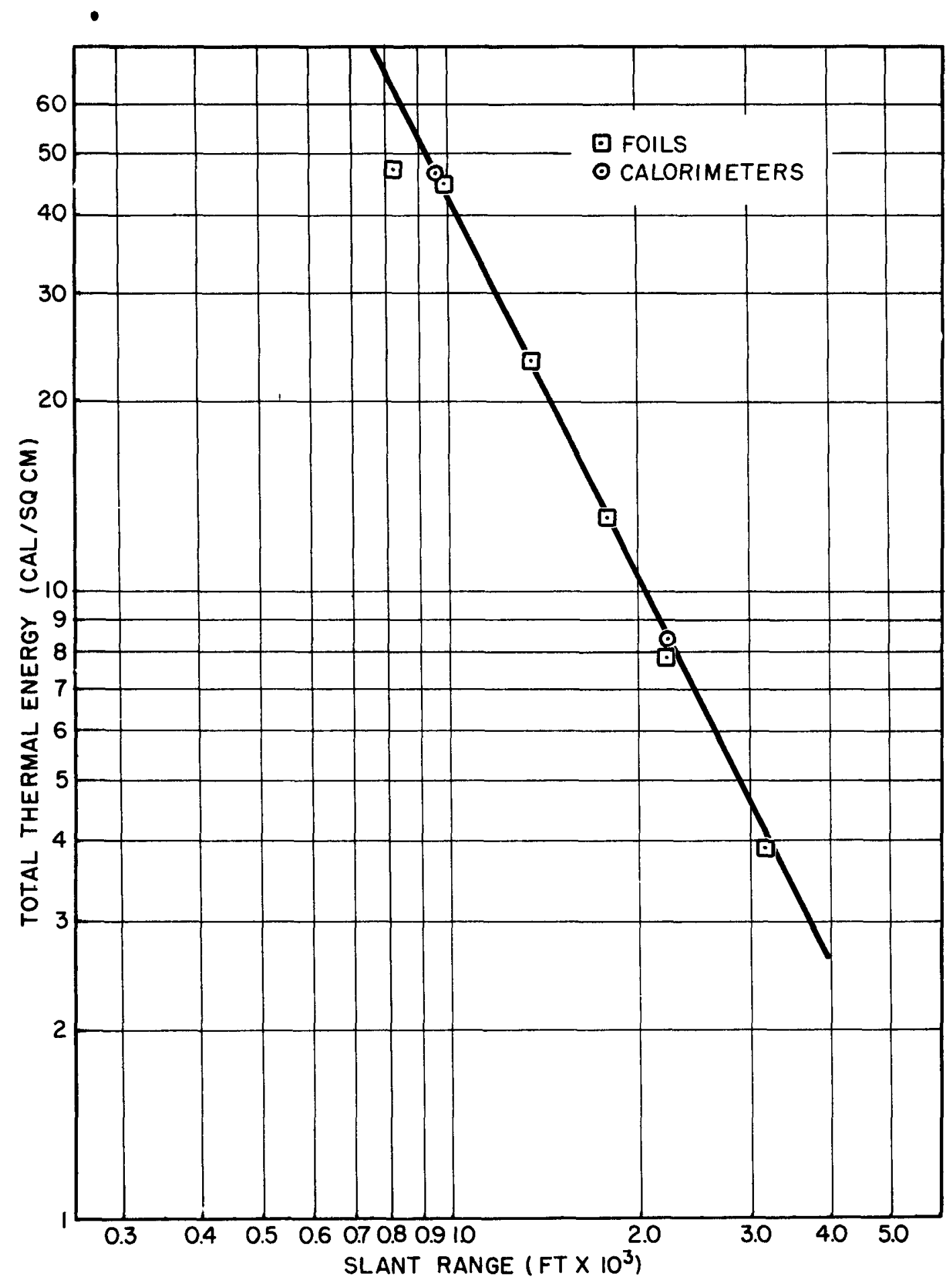

Fig. 5.1 Energy (Cormeted for Atmospheric Attenuation) vs Slant Range, (out ID Calorimeters and Foils 
information

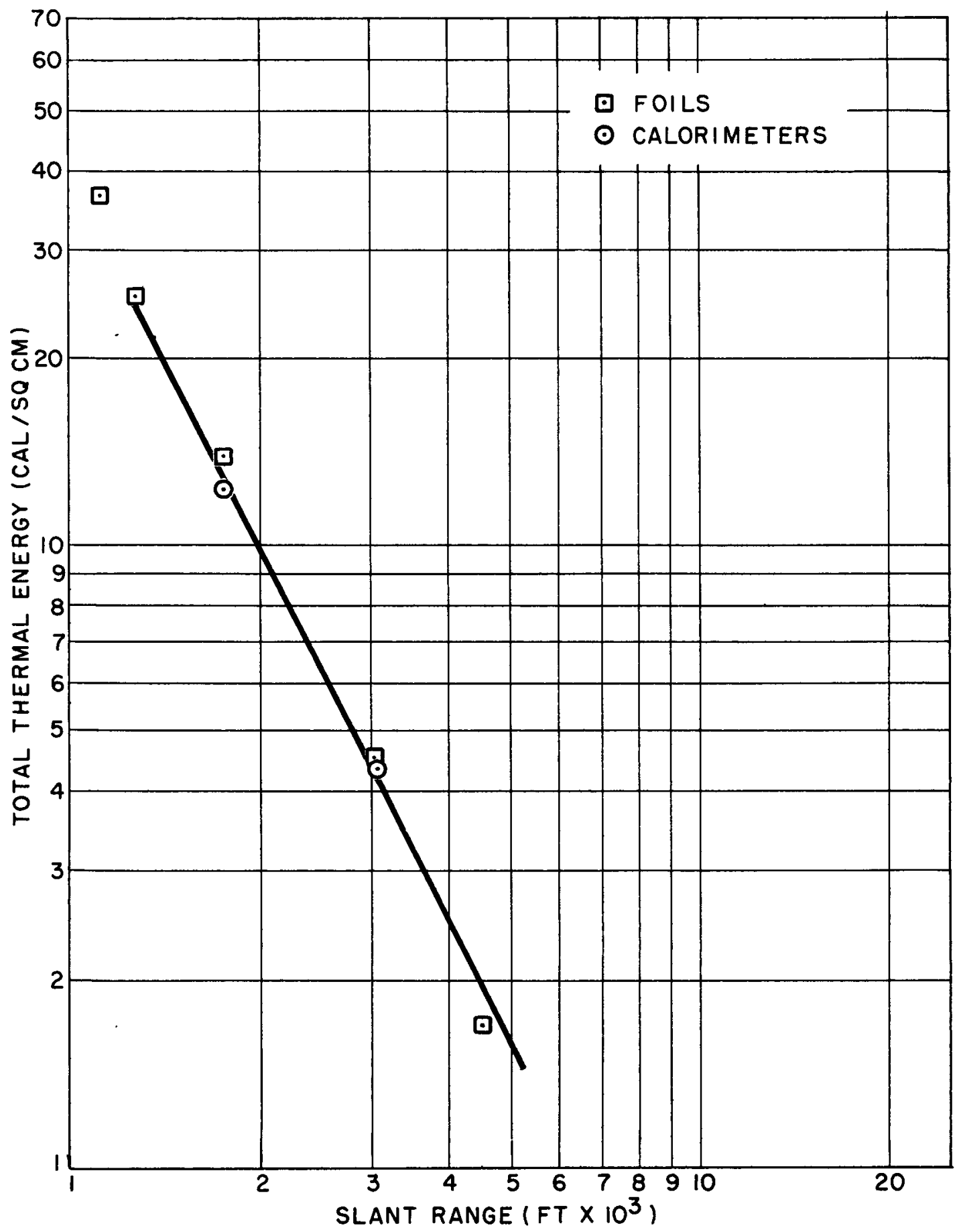

Fig. 5.2 Energy (Eomected for Atmospheric Attenuation) vs Slant Range, Shot 2. Calorimeters and Foils 


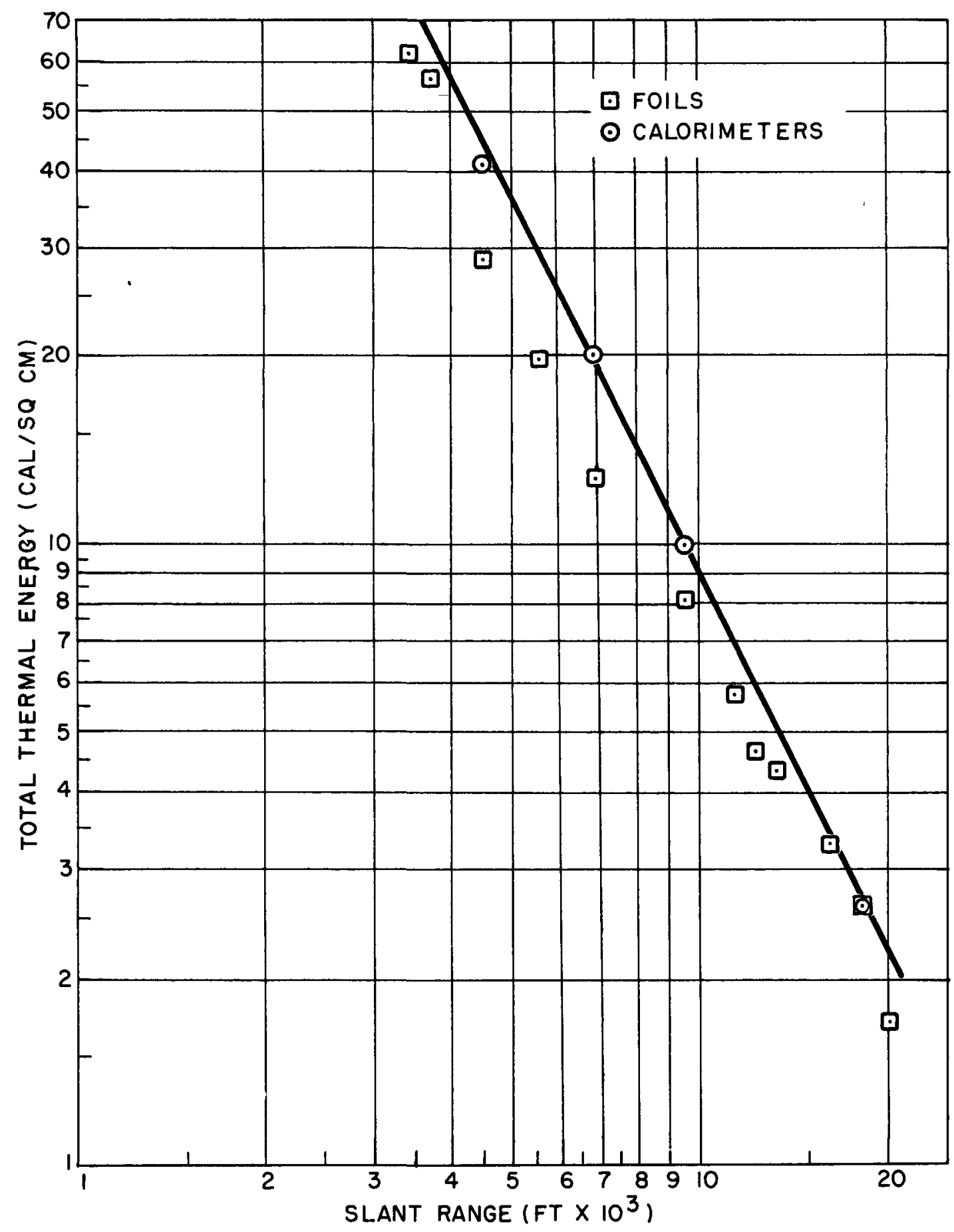

Fig. 5.3 Energy (Gonmeted for Atmospheric Attenuation) vs Slant Range, shot 3 . Calorimeters and Foils 


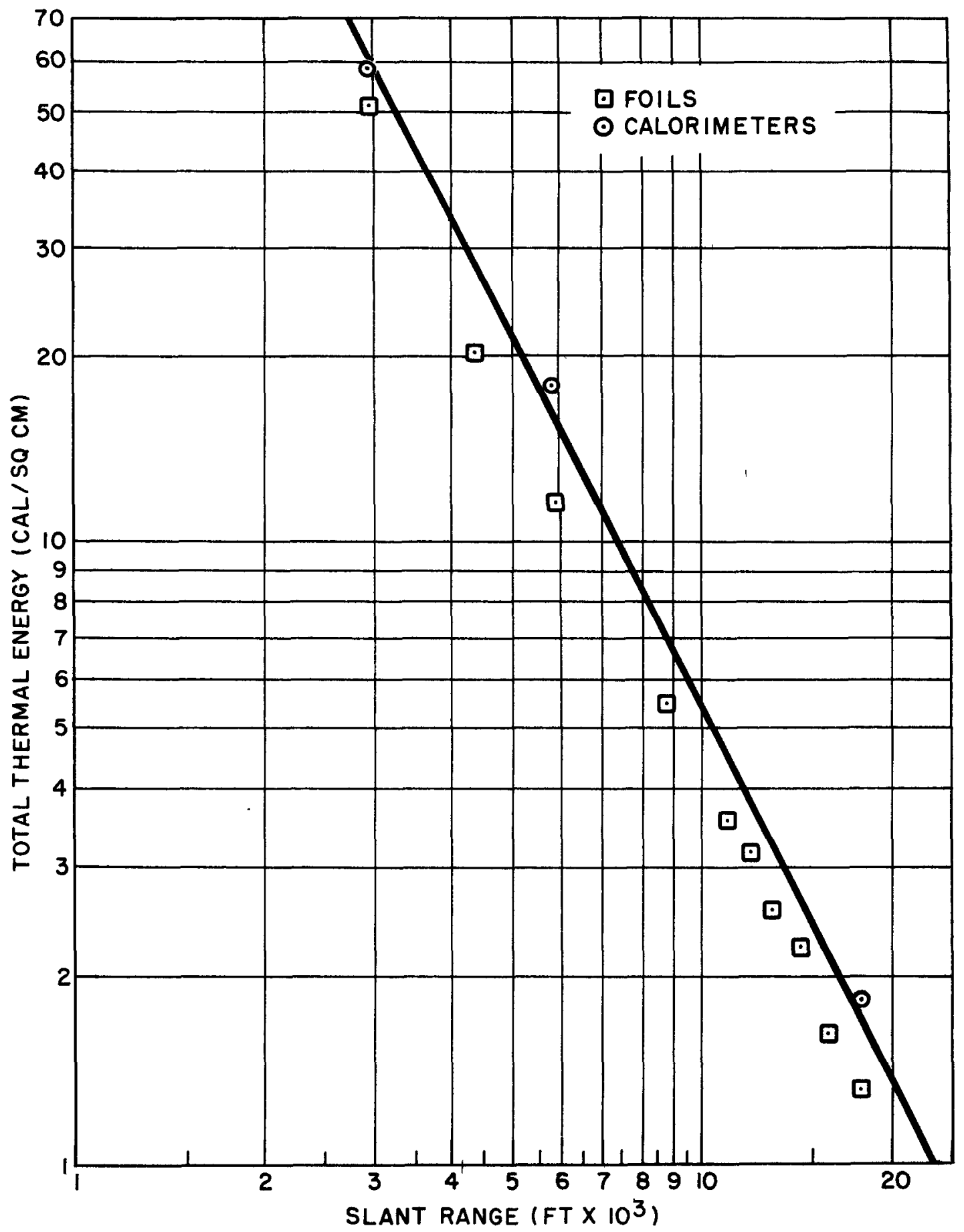

Fig. 5.4 Fnergy (Corrected for Atmospheric Attenuation) vs Slant Range, Shot 4. Calorimeters and Foils

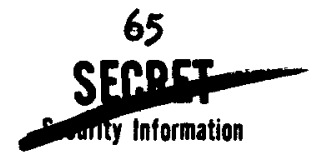




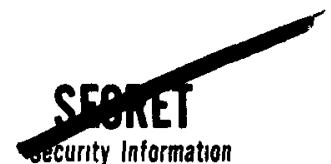

7 per cent and on the average is only a few per cent. Furthermore, as Equation 5.2 has been checked only for half-angles up to $12.5^{\circ}$ there is some doubt as to its validity at much greater angles. Because of the small size and uncertainty of this second-order correction, it was not applied, and the narrow beam transmission values quoted above were used for all fields of view.

An average normalized energy-vs-time curve and intensity-vs-time curve for each shot was obtained by averaging the results from the same calorimeters which were used in the energy-vs-distance plots. In each case the data from four or more calorimeters were used in obtaining the average curve. Figures 5.5 through 5.8, which are the set of individual curves used to obtain the average intensity-vs-time curve for shot 3 indicate the variation in the shape of the curves obtained Irom the various calorimeters.

The composite "best" total energy-vs-time curve for each shot is shown in Fig. 5.9 and the composite "best" intensity-vs-time curve for each shot is shown in Fig. 5.10. Intensity-vs-time curves from Operation BUSTER are given in Fig. 5.11 for comparison purposes. The intensity-vstime curves have been normalized by using the ratio (expressed in per cent) of the intensity at any time to the total energy measured. In addition to permitting comparison of the general shape of these curves, this method of plotting gives an indication of the bomb-to-bomb variation of the peak intensity to total energy ratio.

The curves in Fig. 5.10 indicate that the time to reach peak intensity increases with increasing yield while the ratio of peak intensity to total energy decreases. Although not completely shown in this figure, the larger bombs show much longer thermal talls, measurable energy being recorded out to 6 or $7 \mathrm{sec}$. The curve for shot 4 seems to crifler apprectabif in shape (Iroin the curves for the other three shots.) The peak rises to a higher value than would be expected for a bomb $6 I$ that size, and the intensity then drops rapidly to a long tail. Comparison with the Operation BUSTER data in Flg. 5.11 indicates good agreement between data for the two operations.

The agreement among the various calorimeter values for each shot was quite good, as can be seen from the total energr-vs-distance curves in Flgs. 5.1 through 5.4. An indication of the constancy of thermal vield may be obtained by plotting the log of the total thermal energy (corrected for atmospheric attenuation) per kiloton as a function of distance. This has been done in Fig. 5.12 for Shots 1 through 4, Operation TUMBLER-SNAPPER, and for Shots Baker through Easy, Operation BUSTER. The line drawn through the points has a slope of -2 . In general the fit is fairly good, although there is some indication that the bombs of lower yield gave points above the line while those of higher yield gave points on, or slightly below, the line. This variation can be seen more clearly in Fig. 5.13, which is a log-log plot of the thermal yield vs the total yield, and Fig. 5.14 which 

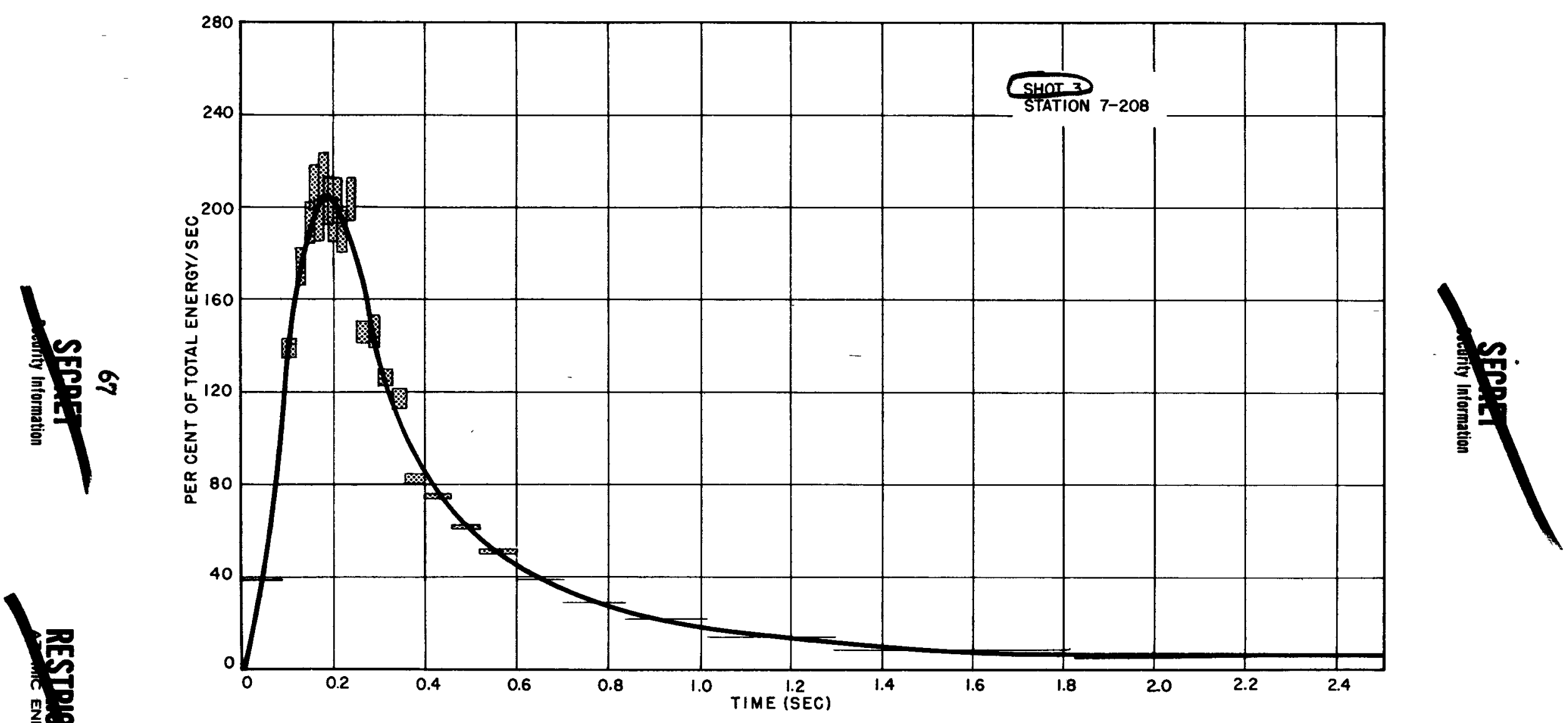

Fig. 5.5 Typical Individual Time Intensity Curved Shot 3 

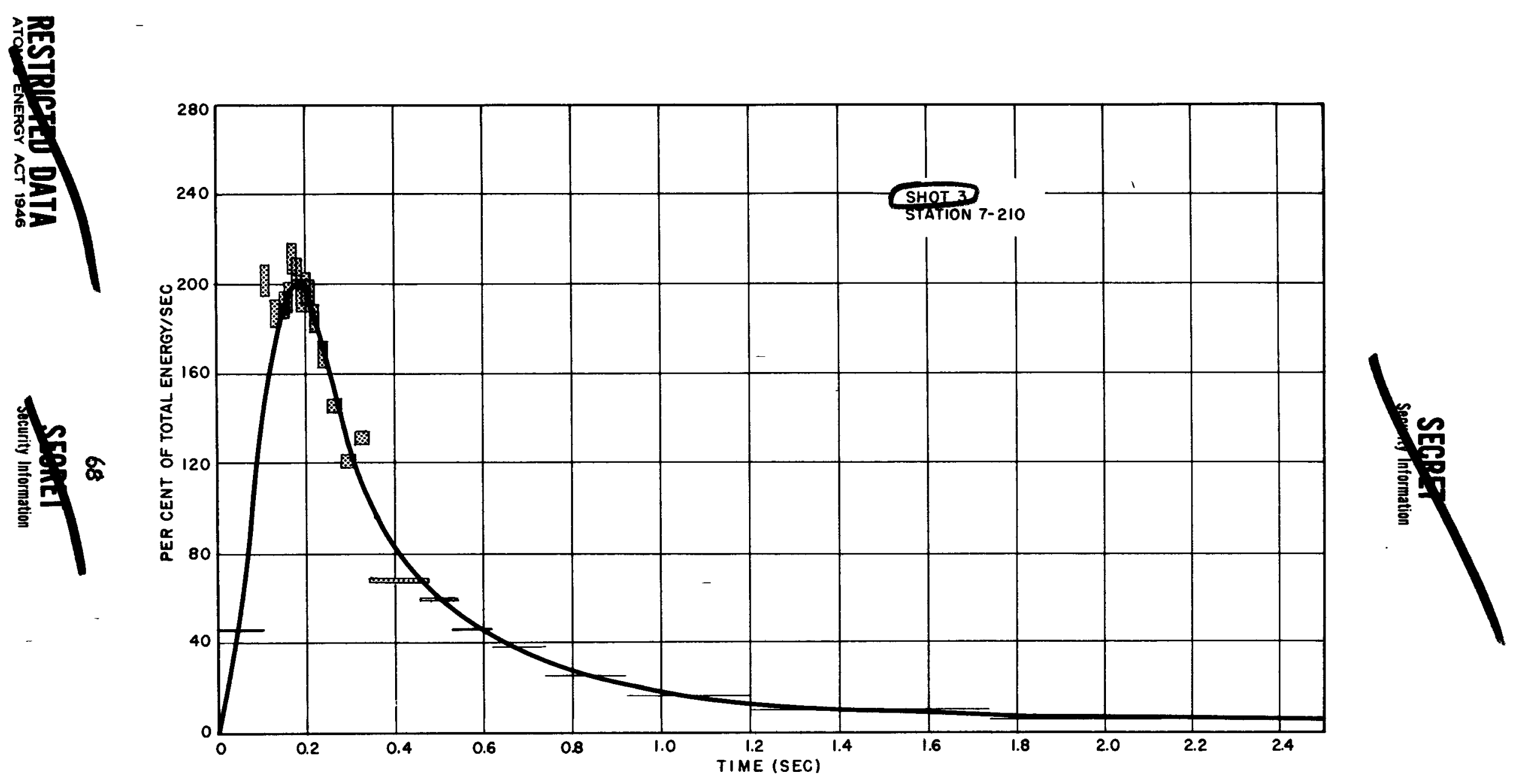

Fig. 5.6 Typical Individual Time Intensity Curves, Shot 3 


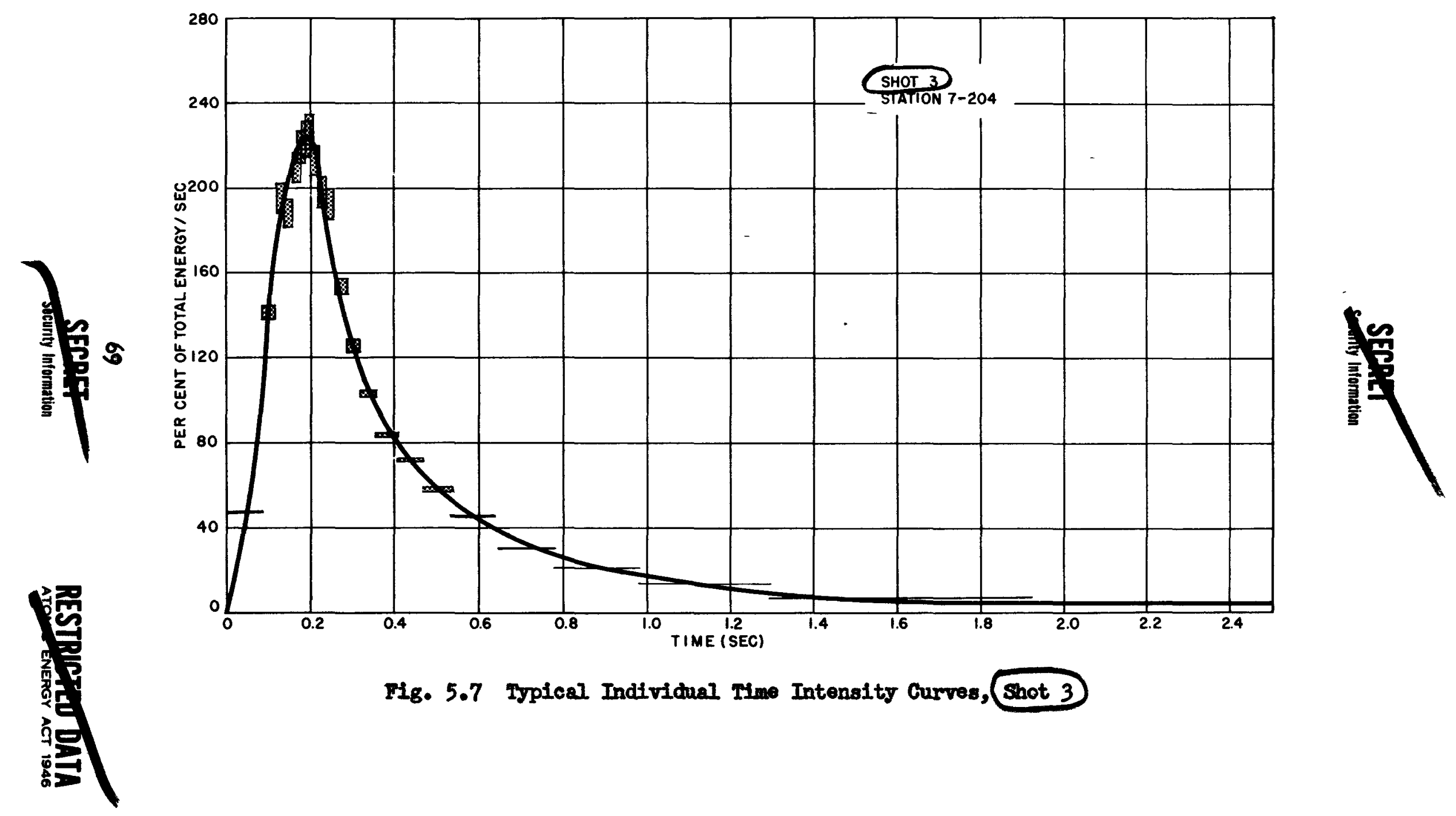




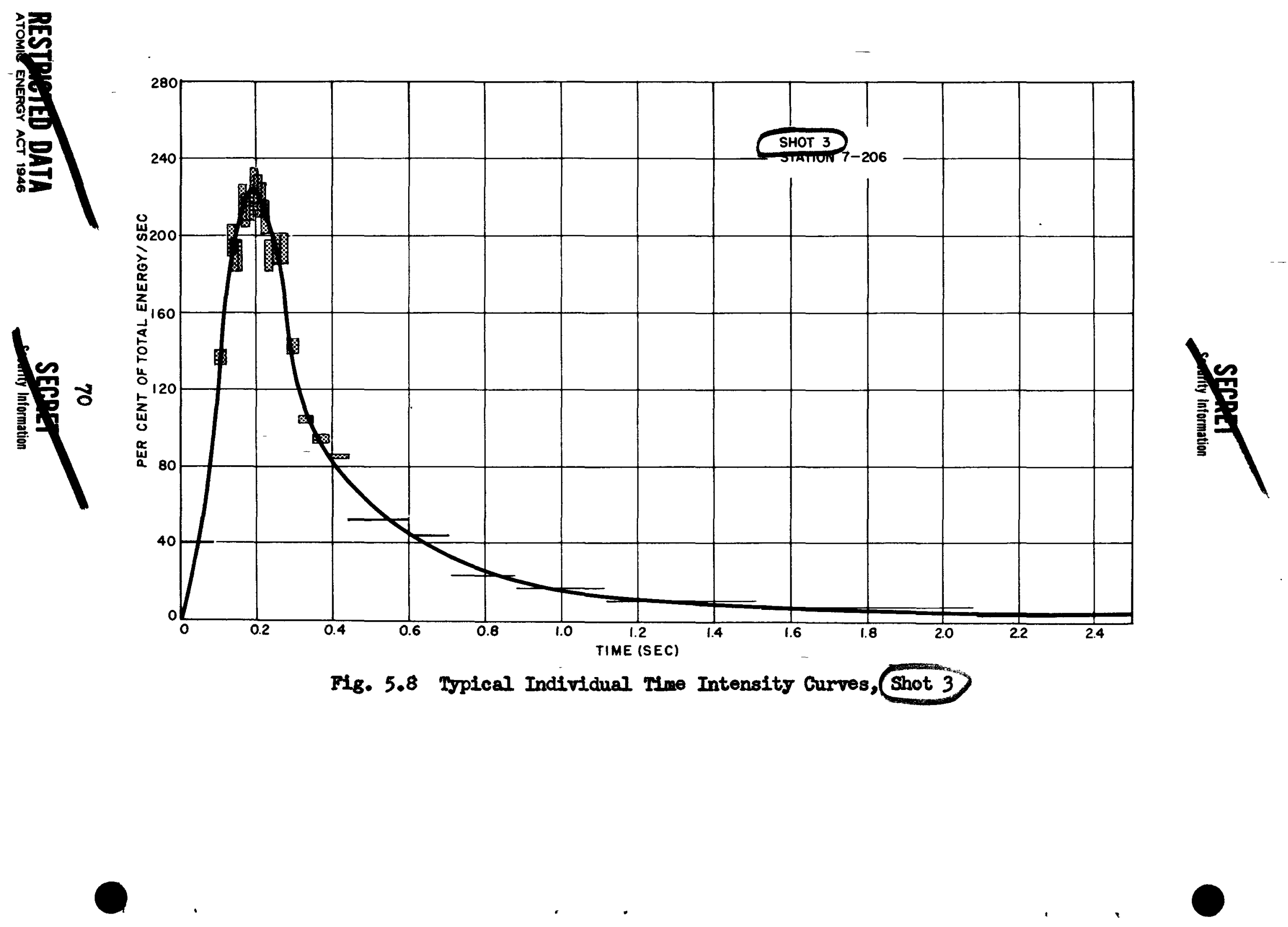




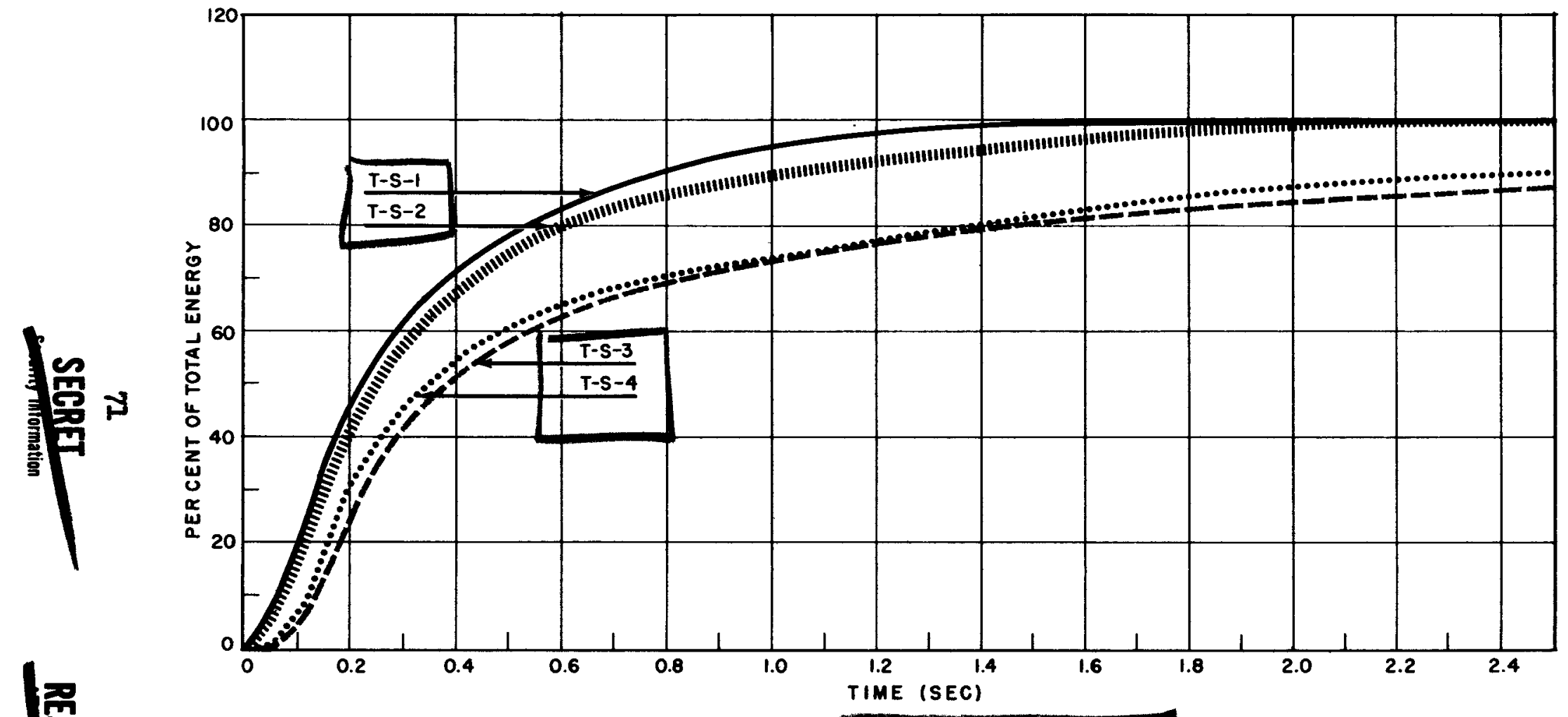

Fig. 5.9 Per Cent of Total Energy vs Time for Shots 1 through 4, Operation TULBLER-SNAPPER 

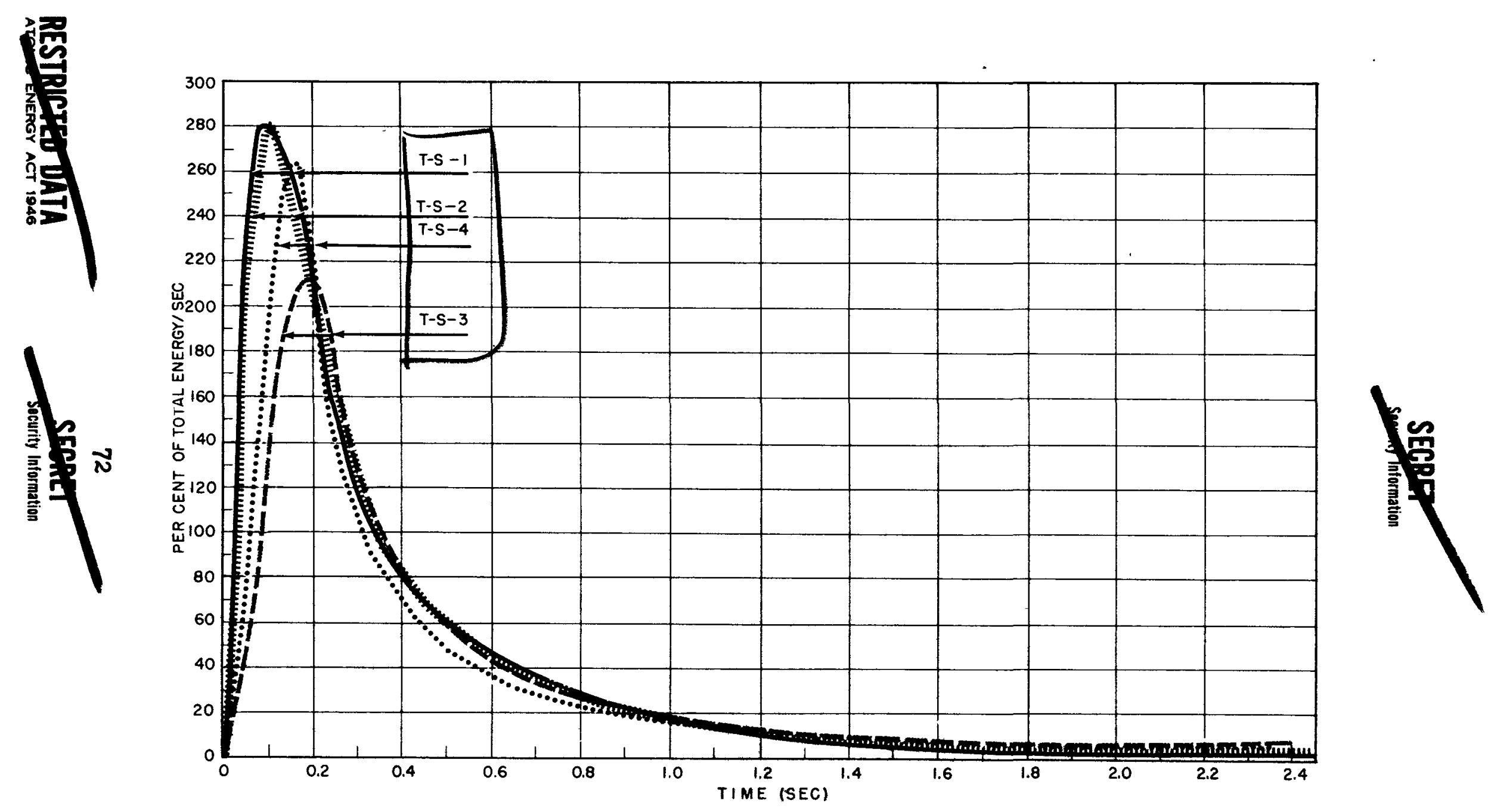
Pig. 5.10 Normalized Intensity vs Time [For Shots I through 4. Operation TUMBLER-
SNAPPER 


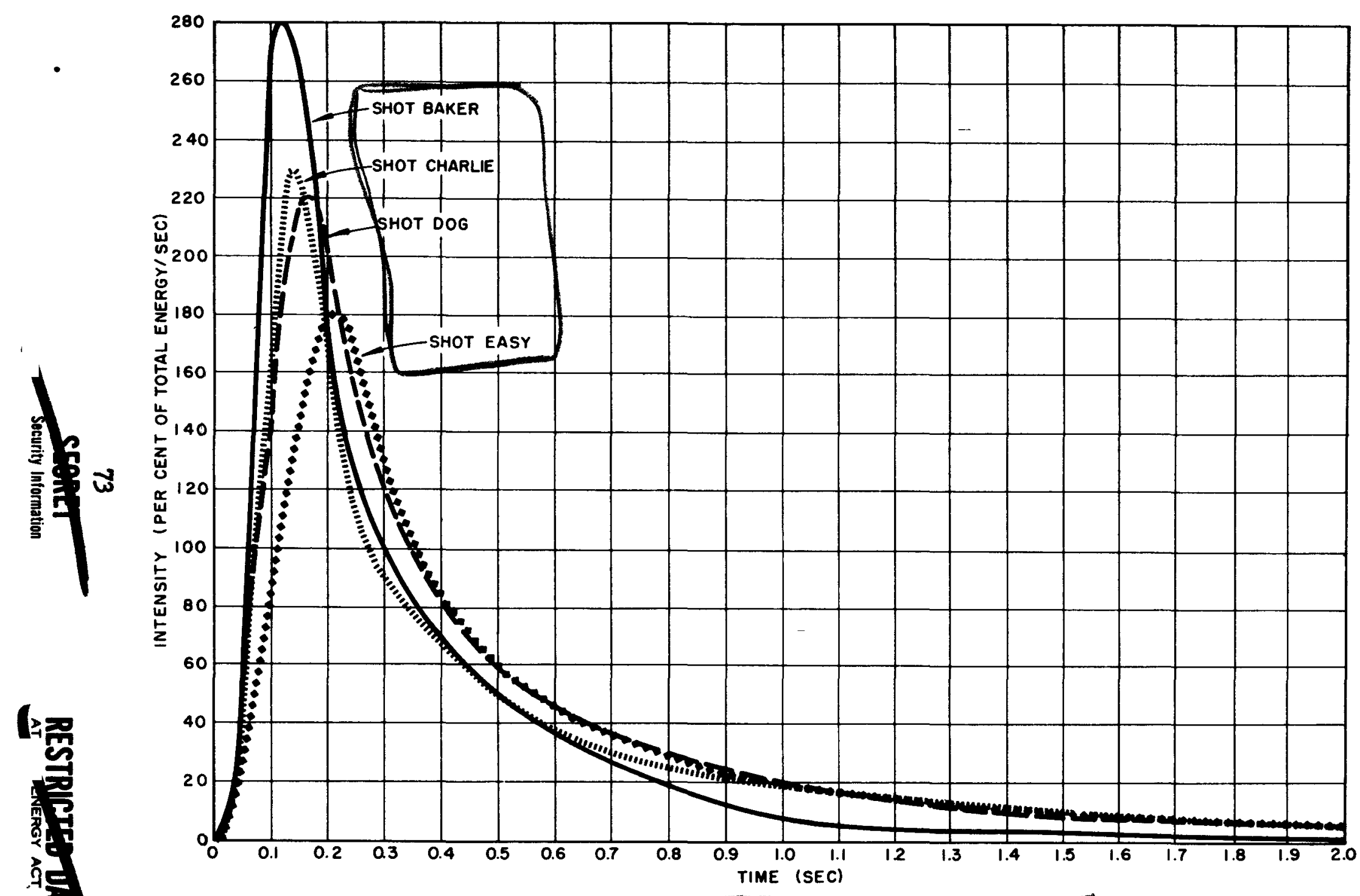

Fig. 5.11 Mormalized Intensity ve Iine for Shots Baker through Eaeg, Operation BUSTER 

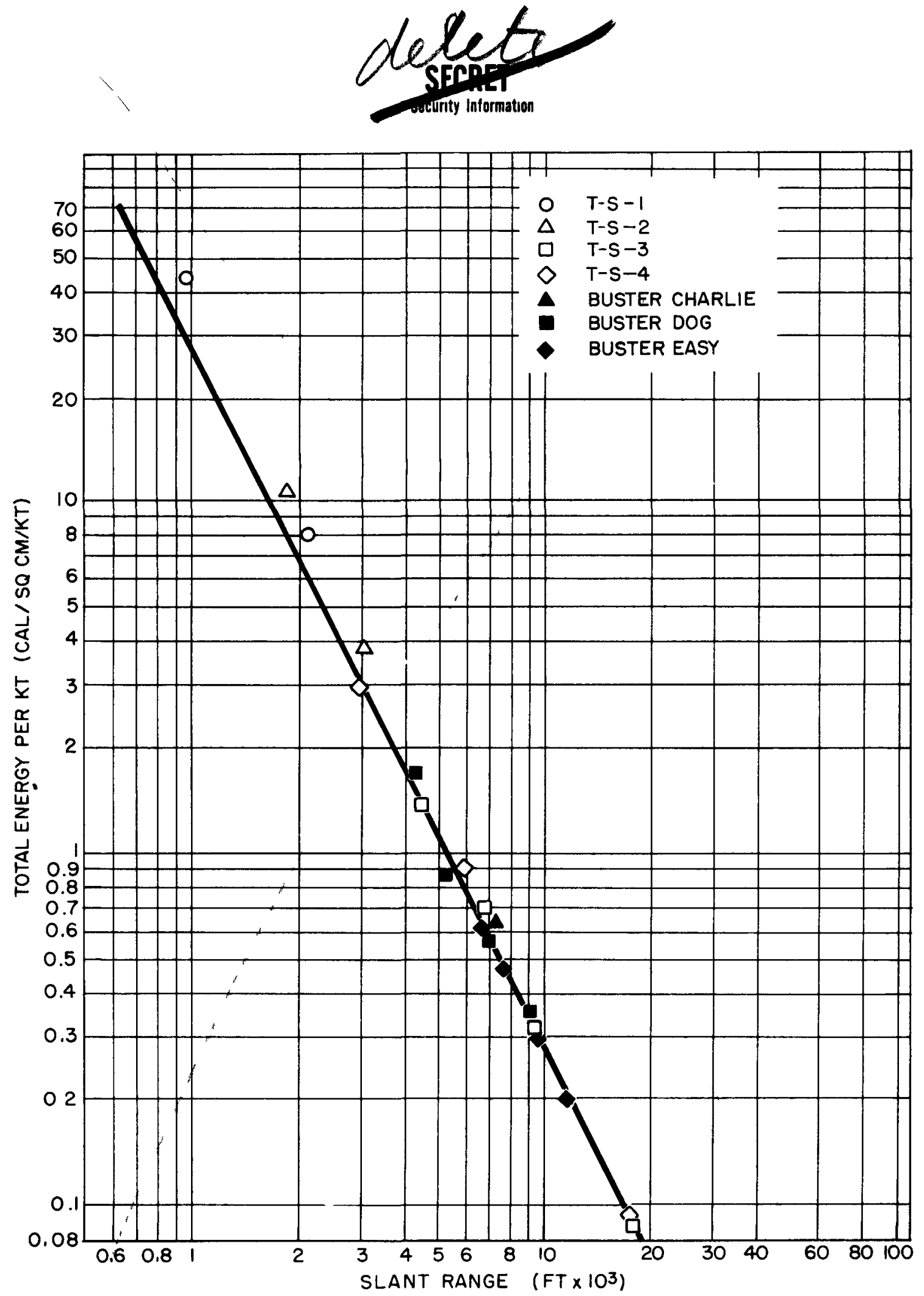

Fig. 5.12 Energy (Corrected for Atmospheric Attenuation) per kt ys Slant Range for Operation TUMBLER-SNAPPER, Shots 1 through 4, and Operation BUSTER, Shots Charlie through Easy
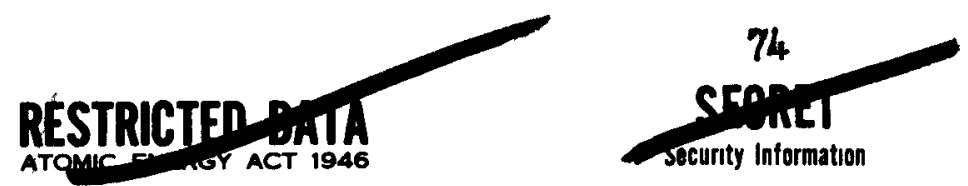


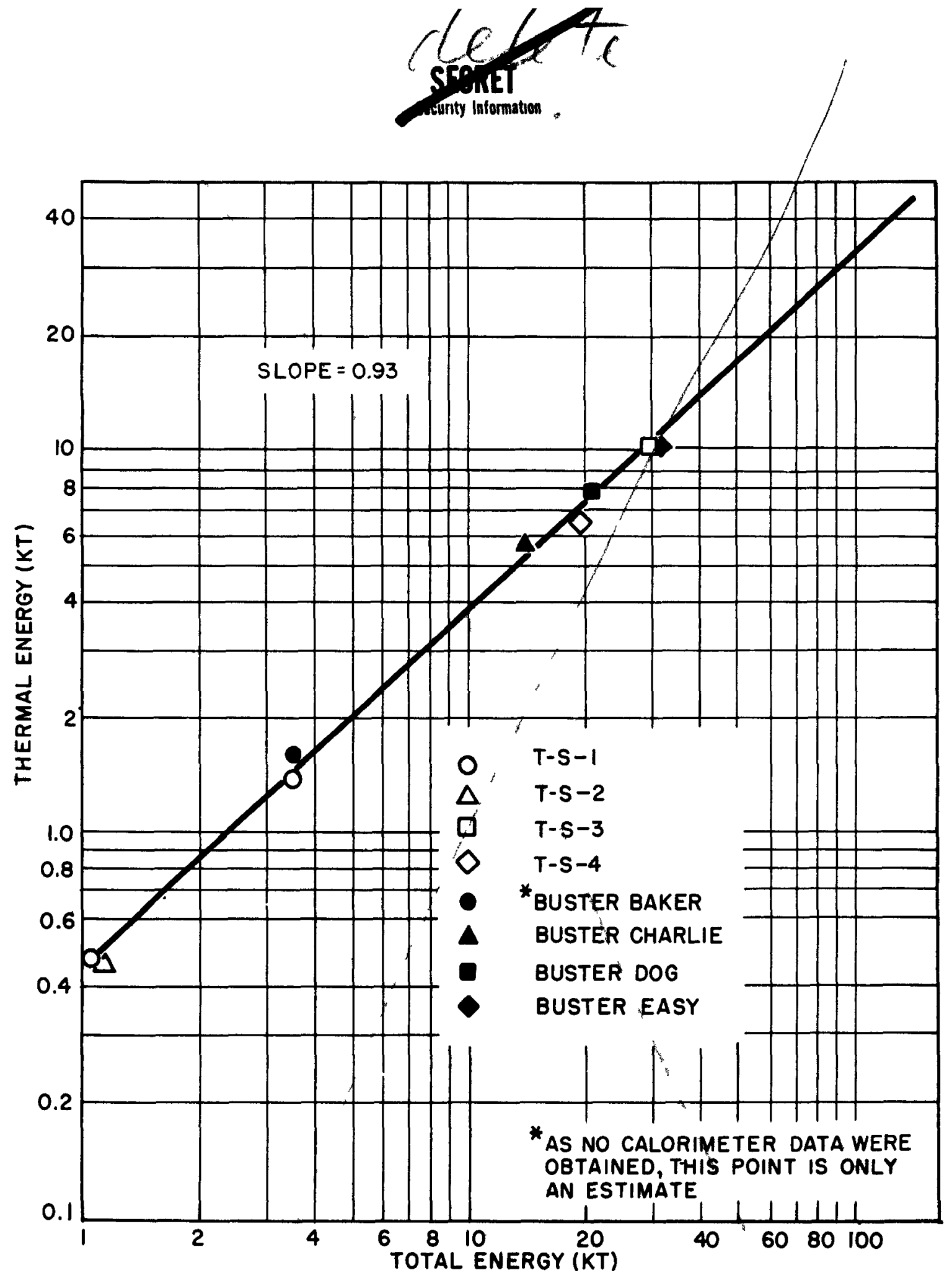

Fig. 5.13 Thermal Iield vs Total Iield for Operation TUBLrr, Shots 1 through 4 and Operation BUSTrR, Shots Baker through Bagy

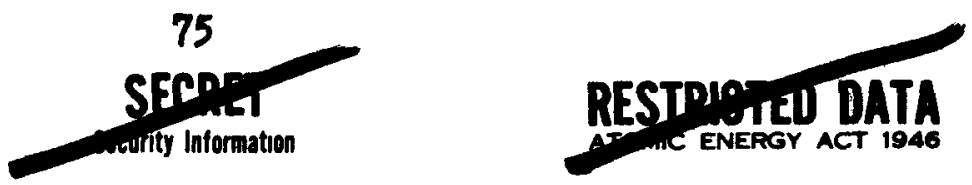




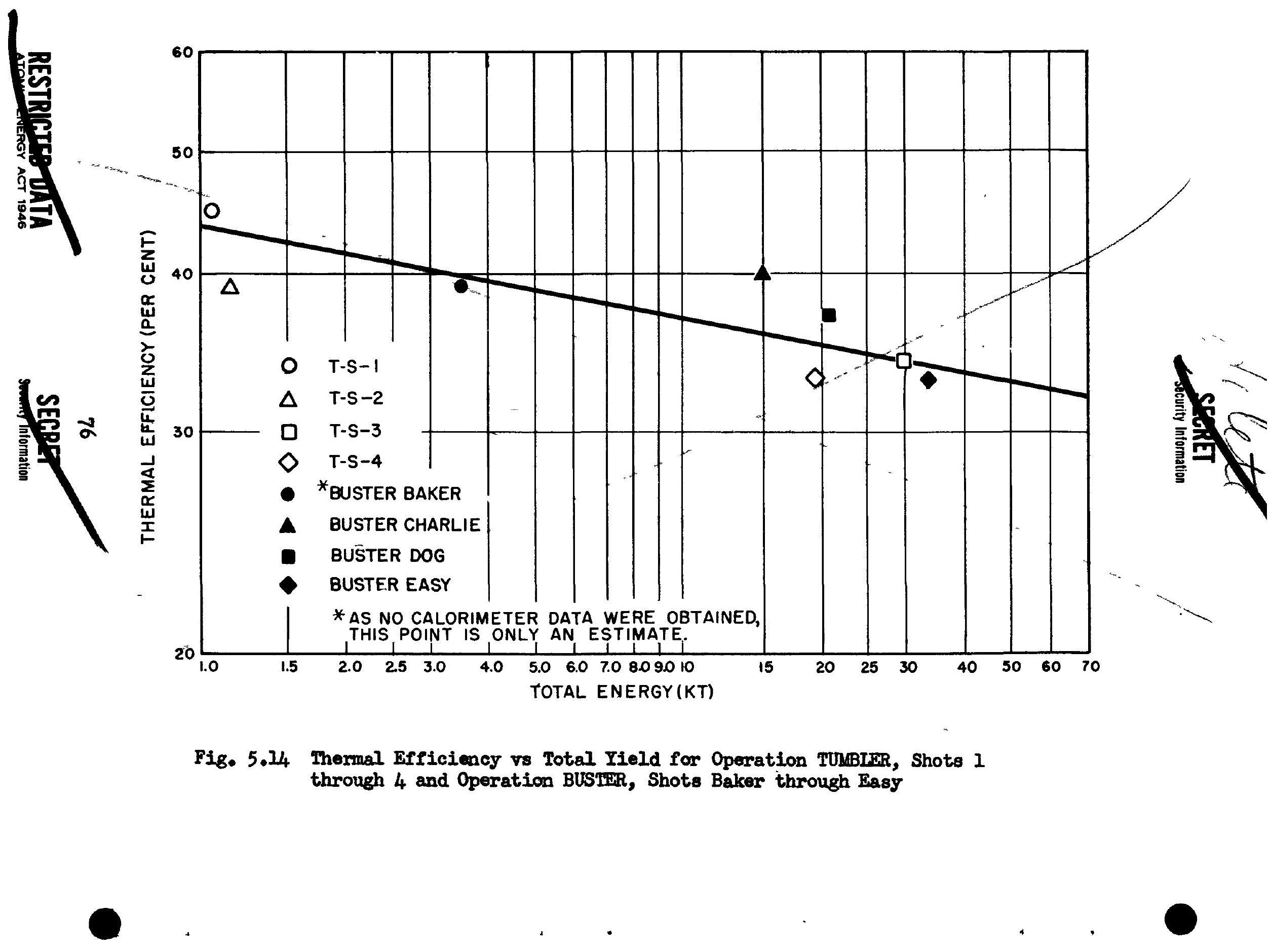




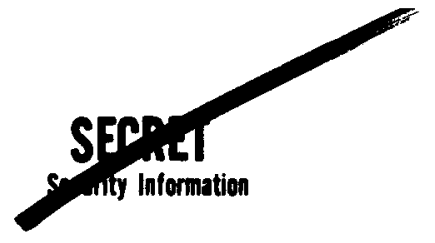

is a log-log plot of the thermal efficiency ro the total Jield. The best straight line through the points in Fig. 5.13 has a slope of 0.93 , and comrespondingly the Iine in Fig. 5.14 has a slope of -0.07 . The slope of these Iines and the individual points are abject to change frem time to time as new values of total glelds are quoted. The slope of the line in Fig. 5.14 is particularly sensitive to amall changes in this parameter. The total gields used in plotting these curves are show in Table 5.1.

MBLE 5.1

Total rields for Operations EOSTER and TUMLER-SUAPPER

\begin{tabular}{|c|c|c|}
\hline Operation & Shot & $\begin{array}{r}\text { Ileld } \\
\text { (kt) }\end{array}$ \\
\hline 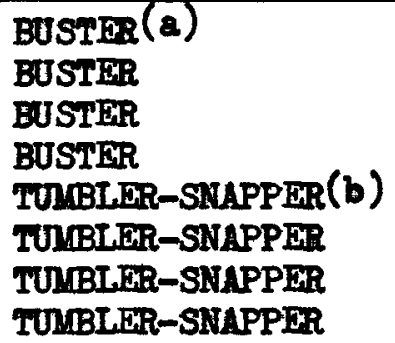 & $\begin{array}{l}\text { B } \\
\text { C } \\
\mathbf{D} \\
\mathbf{E} \\
1 \\
2 \\
3 \\
4\end{array}$ & $\begin{array}{l}3.48 \\
14.0 \\
20.98 \\
31.4 \\
1.05 \\
1.15 \\
30.0 \\
19.6\end{array}$ \\
\hline
\end{tabular}

(a) BUSTER jield data are final radiochemical ylelds and were obtained from letter dated 14 saguat 1952 from It. Col. G. B. Page, Chief, Reports Branch, AFSTP (FIIe Ho. SWRWT/I).

(b)

TULBLER-SWAPPER Jield data are preliminary radiocheaical ylelds and were obtained from letter dated 5 August 1952 fron It. Col. G. B. Page, Chier, Reports Branch, MFSIP (File Ho. SiFwi/i).

\subsection{RADIOMETERS}

Comparison of the thermal pulse ahapes of the bombs, as measured with the various calorimeters and radioneters, are shown in Figs. 5.15, 5.16, and 5.17 for shots 1,2, and 4 rospectively. No comprison was made on shot 3] vockuse of the cast obscuration at Station 7-202 and faflure of the timing mechanian at the 18,000-ft station, which caused the time seale to be uncertain. All curres have been normalized so that tho peak intensity is 100 per cent. It can be seen that, al though the general shape of the curve is eimflar for all instranents, the USIDDC. disk, radioneter and the fine-rire radiometer curvos appear to 1 ag bohind the differentiated calorineter and IIT radianeter curves. This result is reasonable, as the measured time constant of all but the thiekest calorineters is less than 15 msec, that of the VIT radioneter, 12 asce, and that of the USNRDL disk radianeters, 25 to 30 maec. While no laboratory
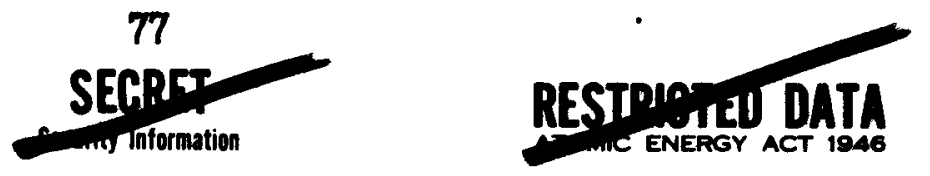

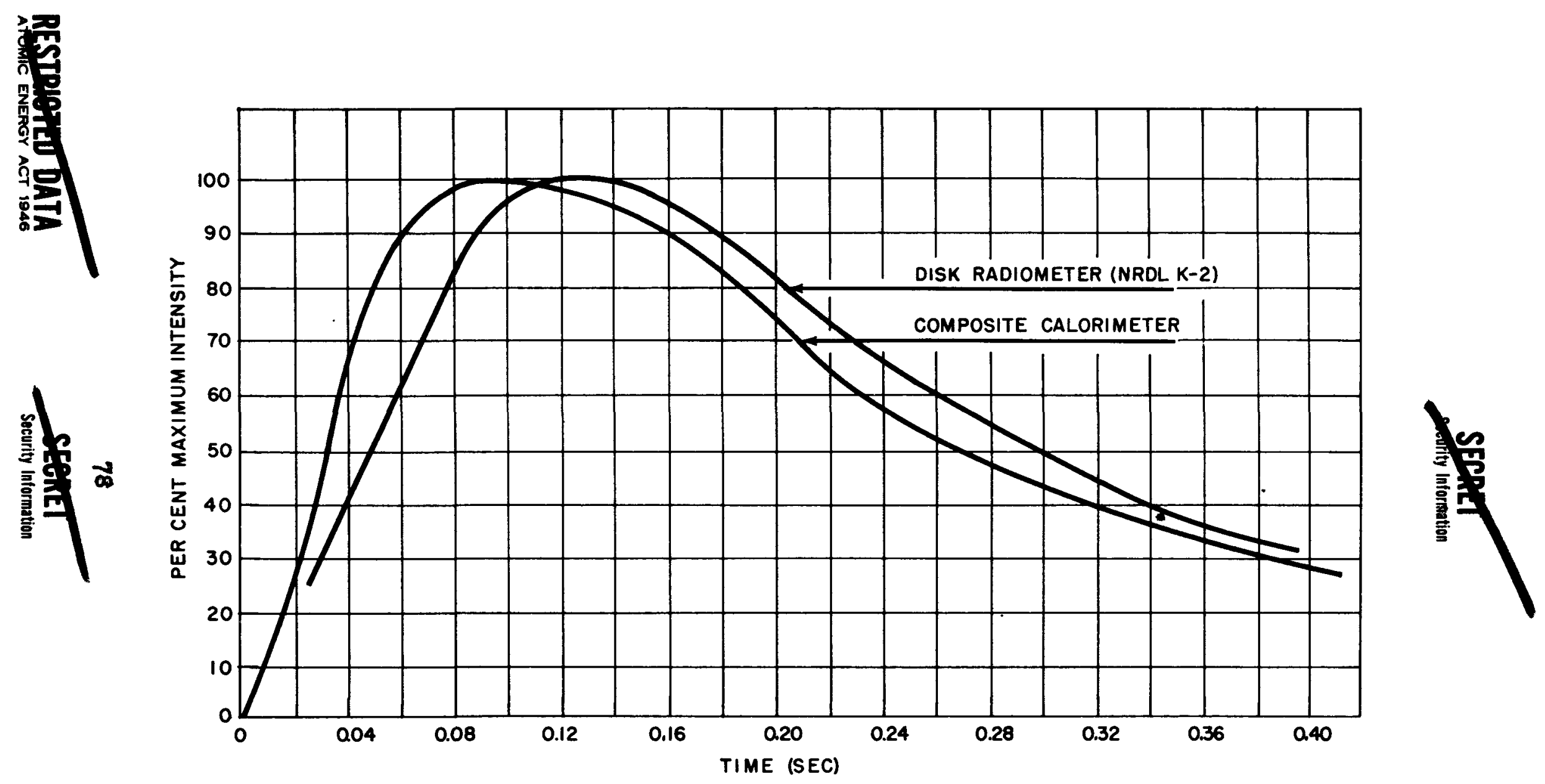

F1g. 5.15 Intensity-vs-time Curves from Various Instruments, Shot I 


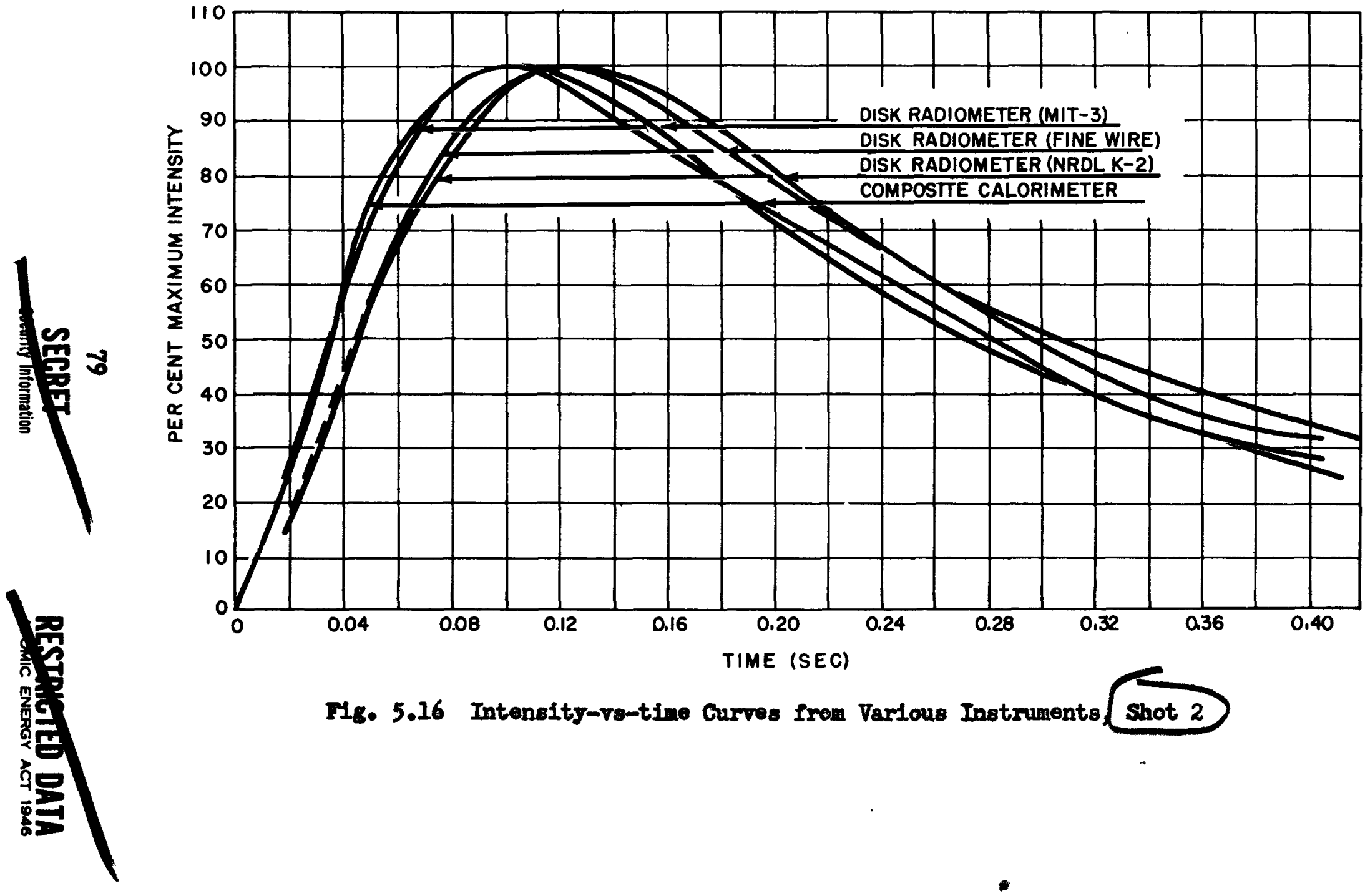



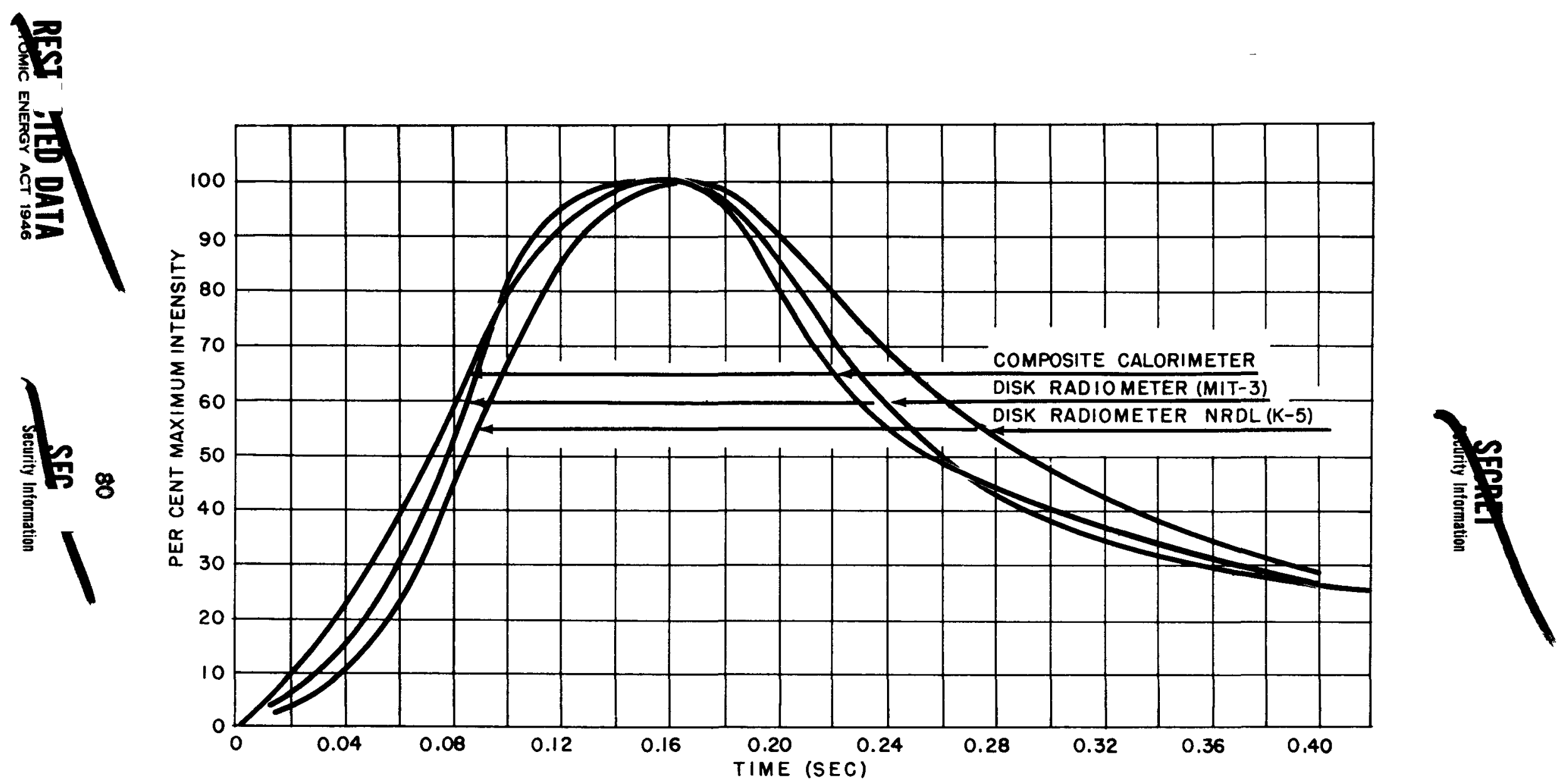

Fig. 5.17 Intensity-vs-time Curves from Various Instrunents, Shot 4 


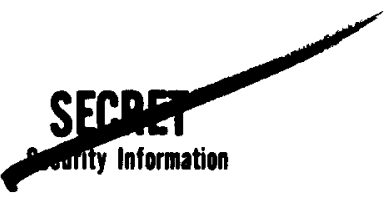

determination of time constant, of the fine-wire radiometer was obtained, the comparison curves for Shot 2 show that its response is very gimilar to that of the USTRWL disk radioneter.

\subsection{SPECTRAL ENERGY DISTRIBNTION}

The results of the spectral investigation are shown in Table 5.2 where the energy received under each filter is given as the percentage of the energy received under quartz. Also show in the table are sinilar results from Operations GREFUHOUSE and BUSTER, along with the percentages expected from a black body at $6,0000 \mathrm{~K}$. The spectral data obtained at Operation GRERHHOUSE, indicate appreciably less energy at,

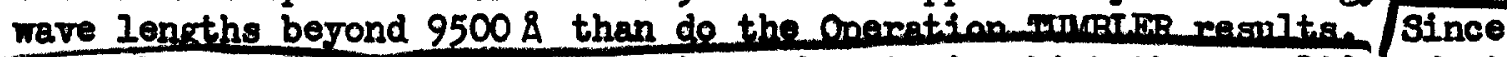
the cREFNHOOSS detonation was a tower burst, in wich the resulting dust clouds obscured the tail of the thernal pulse, and since the thermal tail is rich in the longer wave lengths, a not decrease in the contribution of the infrared would be expected for such a burst.

Figures 5.18 and 5.19 show the normalized intensity-rs-time curres for each of the calorimeters under the various filters. Normalization consisted in dividing the measured intensity by the total energy recelred under the particular filter. The expected gradual shift of the spectral distribution with time can readily be seen.

\section{TABLE 5.2}

Per Cent of Total Energy in the Tranamission Range of the Filters Used in Operation TUMBLER-SNAPPER

\begin{tabular}{|c|c|c|c|c|c|c|c|}
\hline \multirow[b]{2}{*}{$\begin{array}{l}\text { Filter } \\
\text { Type }\end{array}$} & \multirow{2}{*}{$\begin{array}{c}\text { Spectral Range } \\
\text { of Transmission } \\
\AA\end{array}$} & \multicolumn{5}{|c|}{ Per Cent of Energy Received under Quartz } & \multirow[b]{2}{*}{$\begin{array}{l}6.000^{\circ} \mathrm{x} \\
\text { Black Body }\end{array}$} \\
\hline & & $\frac{\text { GRETNHOUSE }}{\text { EAst }}$ & $\frac{\text { BUSTER }}{\text { DOG }}$ & $\begin{array}{l}\text { BUSTER } \\
\text { EASTY }\end{array}$ & $\begin{array}{c}\mathrm{T}-\mathrm{S} \\
3\end{array}$ & $\begin{array}{c}T-S \\
4\end{array}$ & \\
\hline Quartz & $2200-45000$ & 100 & 100 & 100 & 100 & 100 & 99 \\
\hline $0-52$ & $3600-25000$ & 100 & -- & -- & 91 & 91 & 88 \\
\hline 3-69 & $5300-25000$ & 75 & 72 & 79 & 70 & 70 & 66 \\
\hline $2-58$ & $6400-25000$ & 50 & 43 & 53 & 54 & 55 & $\mathbf{5 2}$ \\
\hline $7-56$ & $9500-25000$ & 10 & -- & -- & 25 & 25 & 26 \\
\hline
\end{tabular}

\subsection{LOCAL OBSCURATION: THE ESPECT OF ETEVATION OF YEASURTNG IHSTHUIEUT}

Examination of the energy received at each station (Tables 4.1 through 4.4) as a function of elevation shows that at the close stations, for the larger bombs, there is a noticeable decrease in energy at the grownd level and even at same of the 10-ft levels. Comparison of this parameter for all shots was accomplished by plotting the percentages of energy lost at the grade and 10-ft elevations as functions of the incident total energy (Fig.5.20). For this parpose the total energy was taken fram calorimeters at the 50-ft elevations. Figures 5.21, 5.22, and 5.23, which

81

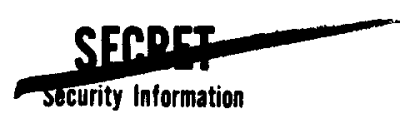




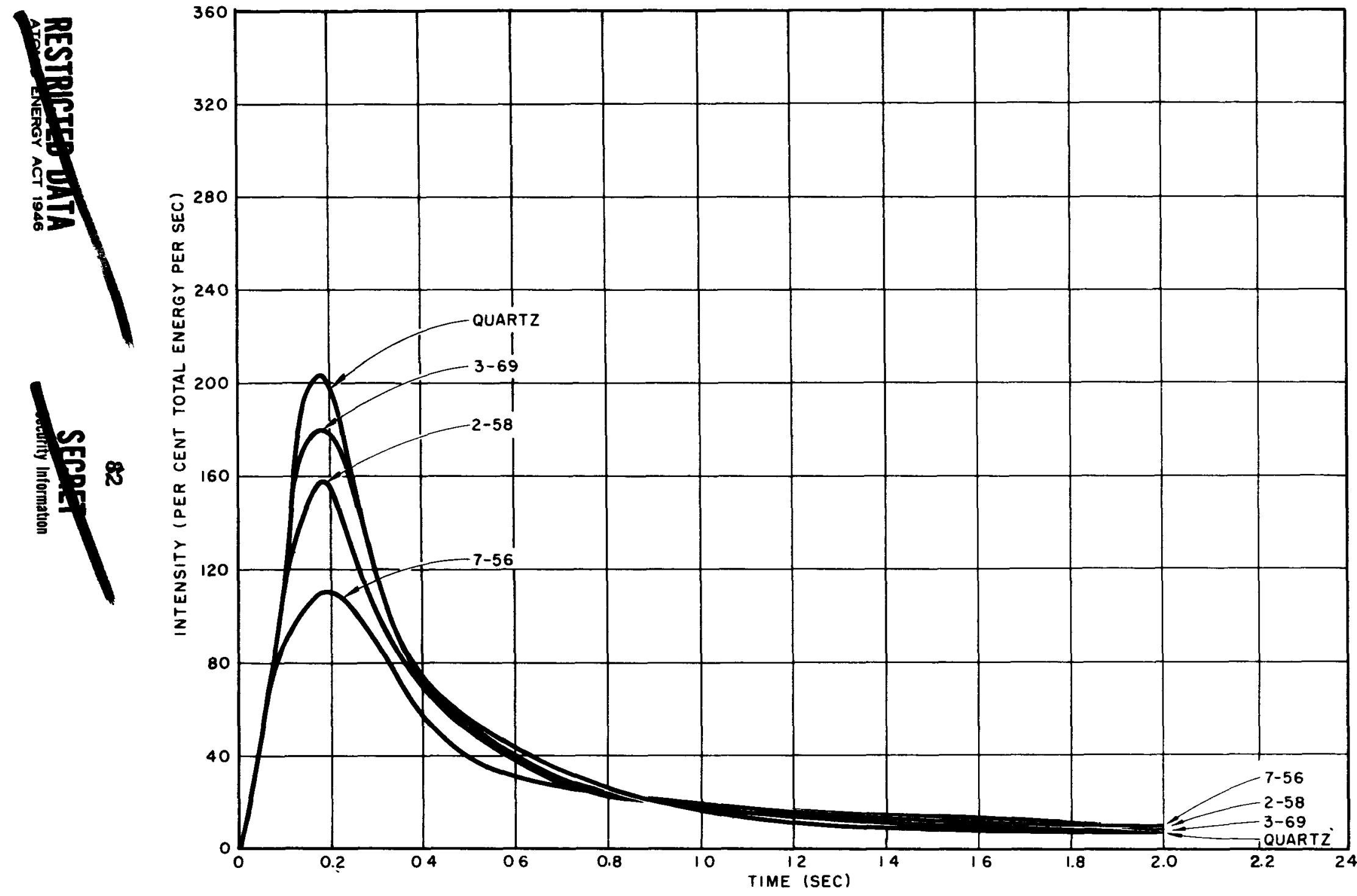

Fig. 5.18 Intensity-rs-time Curves for Calorimeters Used in Spectral Investigation, Shot 3 


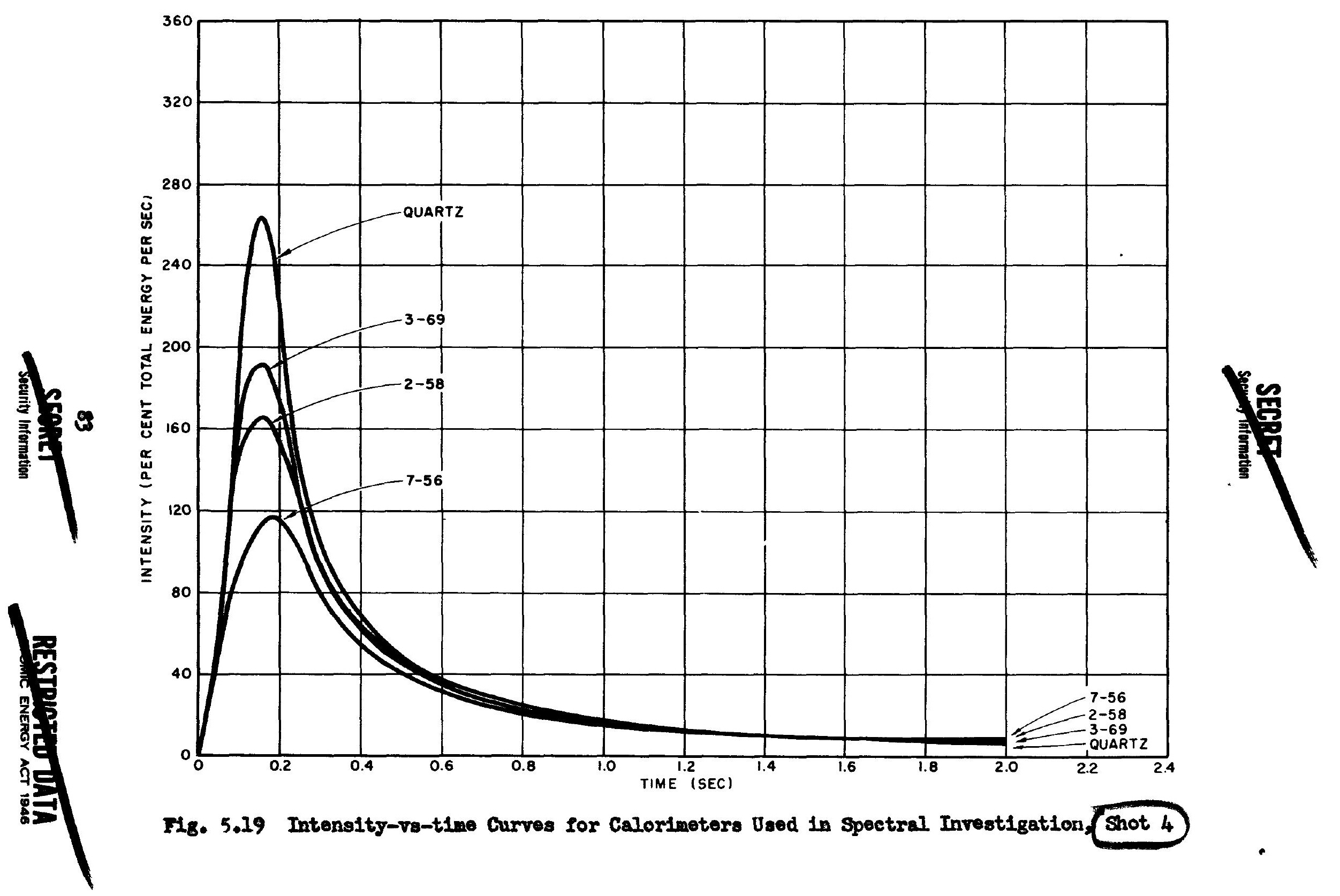




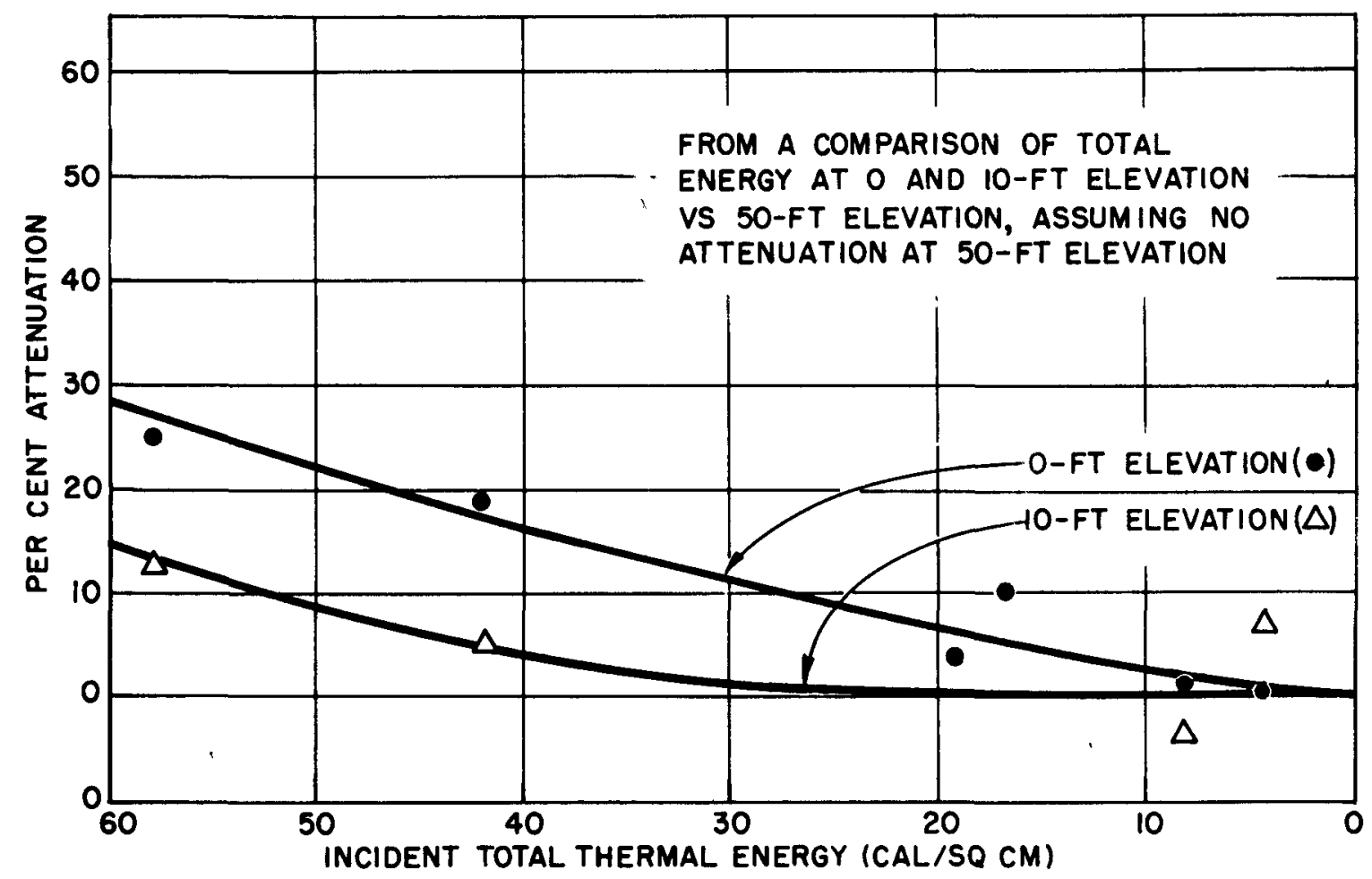

FI8. 5.20 Attemation Due to Iocal Obscuration for Air Bursts 

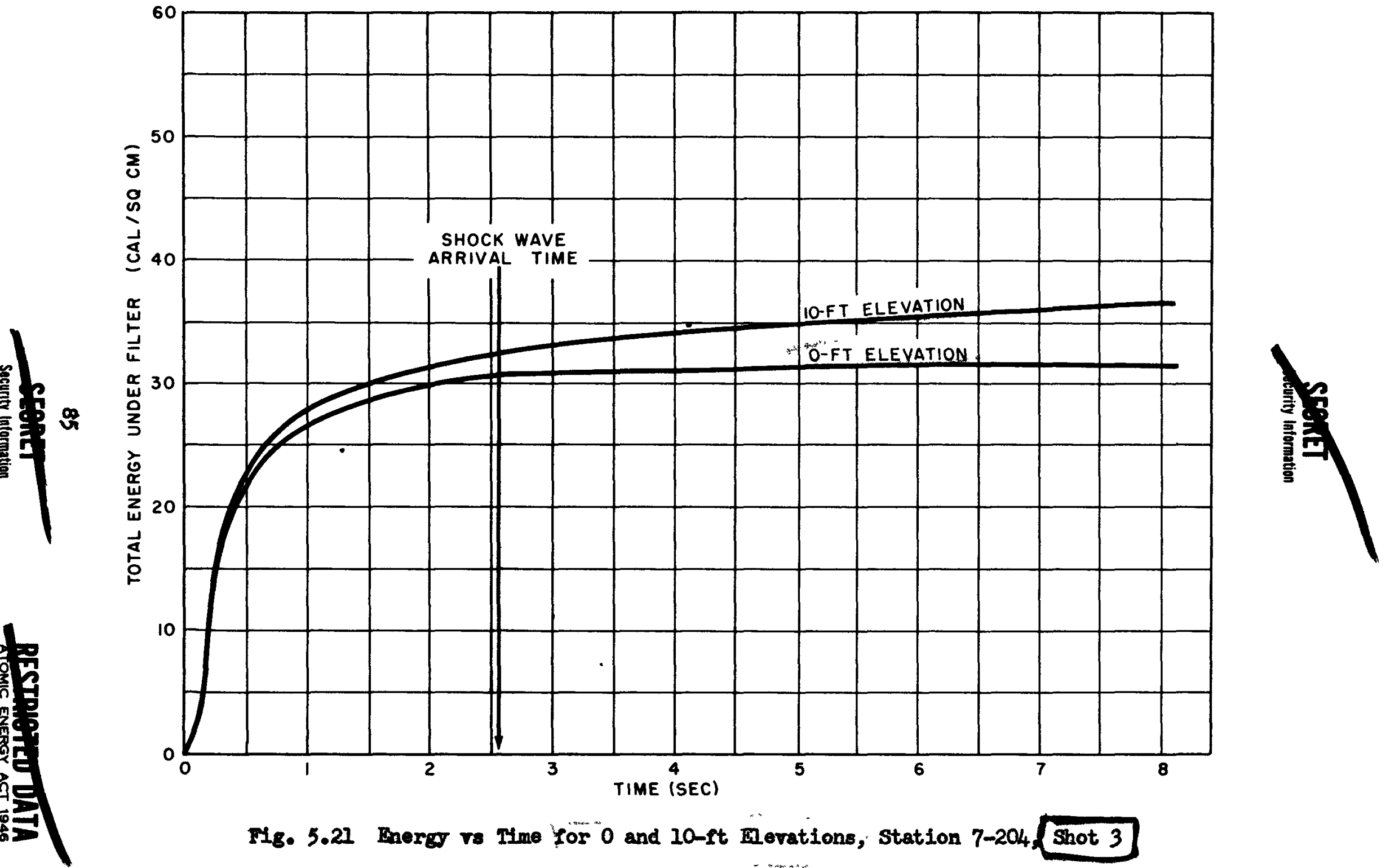

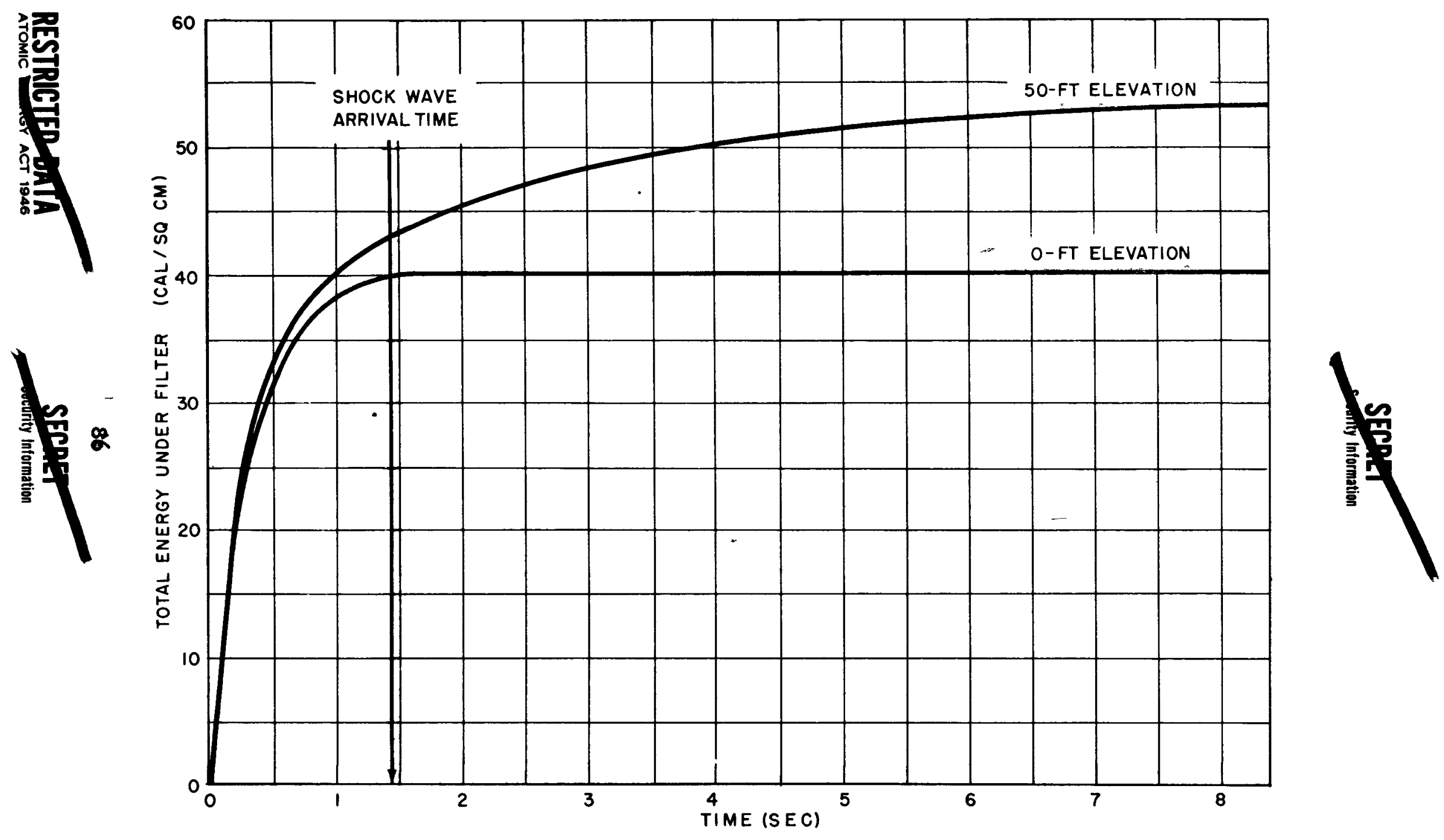

Fig. 5.22 Energy vs Time for 0 and 50-ft Elevations, Station 7-204 Shot 4 


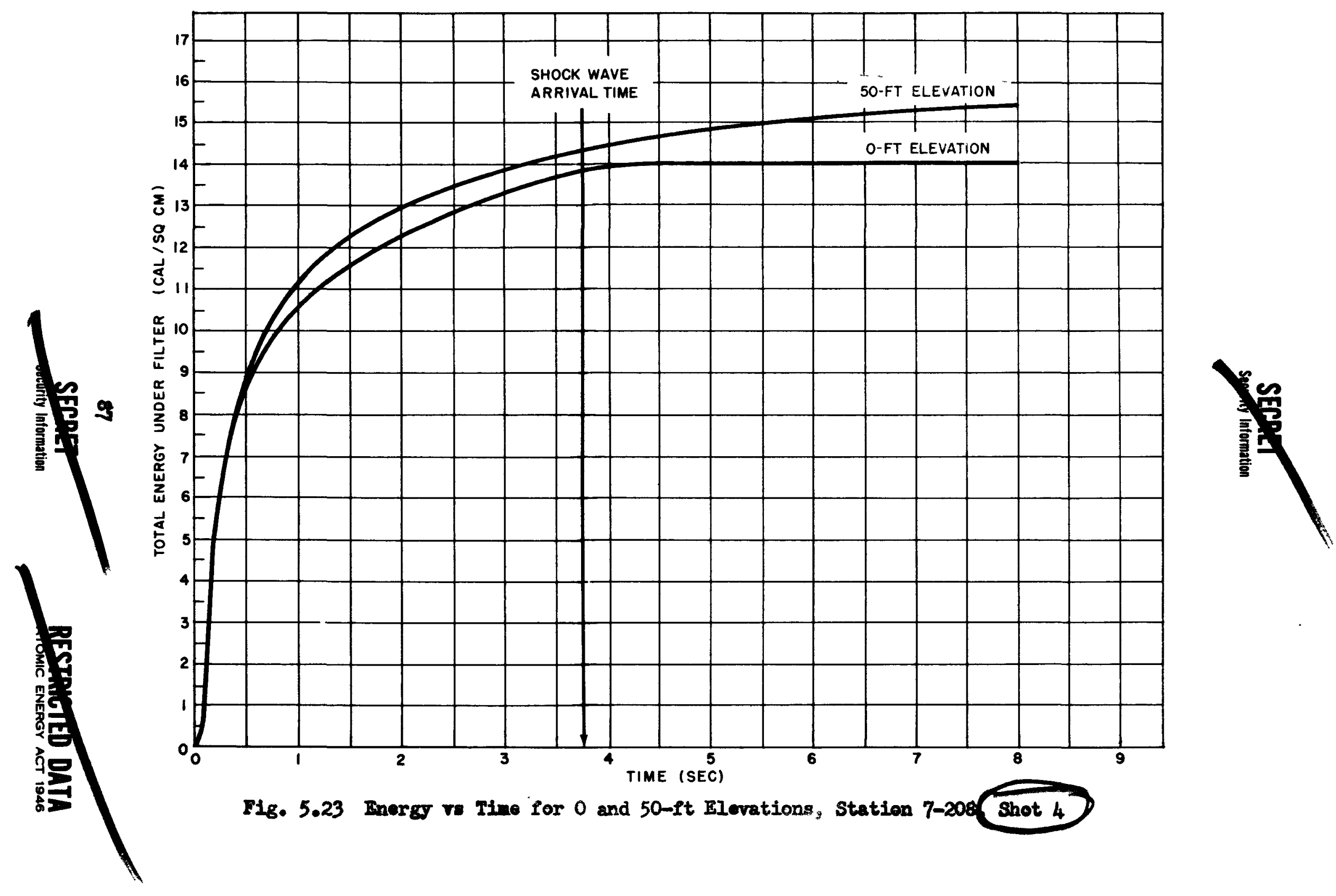




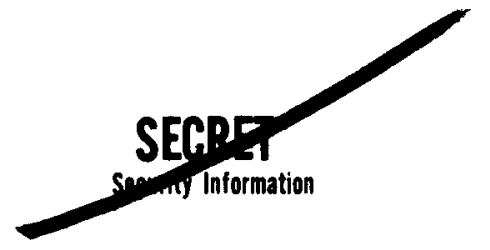

are curres of total energy vs time for various elevations at the three most severely obscured stations, indicate the time sequence of the obscuration. As would be expected, very little energy was received at grade level after arrival of the shock wave. The obscuration before the arrival of the shock wave can be attributed to "popcorning" of the sand and to smoke produced by the burning of ground litter.

\subsection{FIELD OF VIEW}

The results of the field-of-view investigations are shown in Table 5.3. The radius of the fire ball, column 6, was obtained by sealing the value for a nominal (20-kt) bomb, as given in the Effects of Atomic Mrapons, assuming that the radius is proportional to the If 3 power or tie yleld. The radial error in aliganent, colum 7, is the distance betwern the axis of the calorimeter and the expected point of detonation in a plane perpendieular to the axis of the calorimeter, due to an angular orror of $2^{\circ}$, which is the estimated maximum error in alignment. The error in the point of detonation, column 8, is the projected distance between the expected and actual points of detonation in the plane perpendicular to the ads of the cafgrimeter and was obtained from the Operation TUMBLER Preliminary Report1. The estinated maximam displacement of the center of the fleld of view from the center of the detonation, column 9, is the sum of the two errors given above.

\section{TABLE 5.3}

Ffect of Field of View

\begin{tabular}{|c|c|c|c|c|c|c|c|c|c|c|}
\hline $\begin{array}{l}\text { shoo } \\
\text { No. }\end{array}$ & Station & $\begin{array}{c}\text { Slant } \\
\text { Range } \\
\text { (ft) }\end{array}$ & $\begin{array}{c}\text { Elevation } \\
\text { (ft) }\end{array}$ & $\begin{array}{c}\text { Field-of-view } \\
\text { Radius at } \\
\text { Detonation } \\
\text { Point } \\
\text { (ft) }\end{array}$ & $\begin{array}{c}\text { Radius } \\
\text { of } \\
\text { ire oal } \\
\text { (ft) }\end{array}$ & $\begin{array}{c}\text { Radial } \\
\text { Error in } \\
\text { Alignment } \\
\text { (ft) }\end{array}$ & $\begin{array}{c}\text { Error in } \\
\text { Detonation } \\
\text { Point } \\
\text { (ft) }\end{array}$ & $\begin{array}{c}\text { Estimated } \\
\text { Maximum } \\
\text { Displacement } \\
\text { (ft) }\end{array}$ & $\begin{array}{r}\text { Per C } \\
\text { Energ } \\
\text { by C } \\
\text { for H } \\
6^{\circ}\end{array}$ & $\begin{array}{l}\text { Total } \\
\text { eceived } \\
\text { rimeter } \\
\text { Angle } \\
12^{\circ}\end{array}$ \\
\hline \multirow{7}{*}{$\begin{array}{l}1 \\
1 \\
3 \\
3 \\
3^{(b)} \\
4^{(b)} \\
4^{(b)}\end{array}$} & F-208 & 2,220 & 0 & 470 & 170 & 77 & 122 & 199 & $=$ & $o(a)$ \\
\hline & F-208 & 2,210 & 10 & 470 & 170 & 77 & 122 & 199 & $\cdots$ & 83 \\
\hline & $7-204$ & 4,510 & 0 & 960 & 520 & 154 & 124 & 276 & -- & 41 \\
\hline & $7-204$ & 4,500 & 10 & 960 & 520 & 154 & 124 & 276 & -- & 86 \\
\hline & $7-208$ & 6,830 & 0 & 720 & 520 & 240 & 124 & 364 & 46 & -- \\
\hline & $7-204$ & 3,020 & 0 & 640 & 450 & 106 & 153 & 259 & -- & 61 \\
\hline & $7-208$ & 5,920 & 0 & 620 & 450 & 208 & 153 & 361 & 40 & -- \\
\hline
\end{tabular}

(a) It is believed that this value is due to a faulty circuit.

(b) Fir ball could have been partly outside the fleld of view.

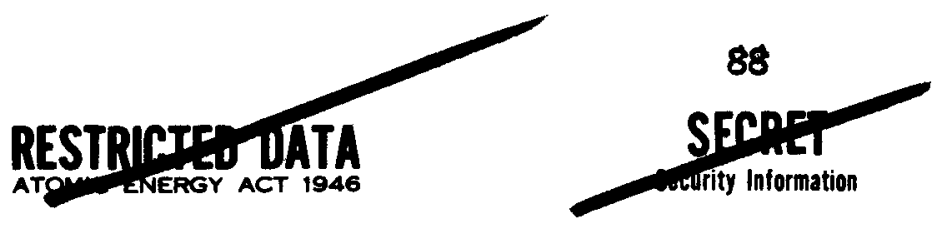




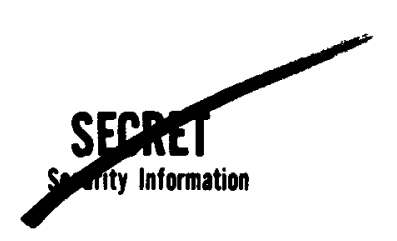

Bxamination of this table shows that the field of Vien should have included the entire fire ball in all but three cases. Fren in those three cases it appears that not more than about 20 or 30 per cent of the fire ball could have been outside of the fleld of view of the calorimeter. The data, however, do not agree with this conclusion, as some of the calorimeters gave values as 10 as 40 per cent of those measured with maximum field of view. It is apparent that important factors other than the errors in alignment and in point of detonation are influeneing the results. One trend that can be noted from the table is that the values obtained at the ground level seemed to shom much lower percentages than those obtained above grade. For example, |for shot 3. Station 7-204, the calorimeter at 10 ft with $12^{\circ}$ half-angle gur of pol cent of the energy measured by the standard calorimeter (half-angle $45^{\circ}$ ) at that elevation, and the one at grade gave 41 per cent of the energy measured by the standard calorimeter at grade. This indicates that dust obscuration might have sone influence on the results. Howerer, additional data must be obtained before the reason for the low results with restricted field of view can be confirmed.

As mentioned previously, the effect of field of view of the measuring device has little effect on the energy received for highly transmitting atmospheres and moderate distances. However, this is not necessarily true when instruments are obscured by smoke or dust, as in this case the collimated transmission could be very low. Using Equation 5.2 and assuming as a limiting case that the collimated transmission approaches zero, the calculated ratios of the energy recelved by the 6 and $12^{\circ}$ half-angle fieldof-view calorimeters to that receired by the $45^{\circ}$ half-angle field-of-view calorimeter would be 0.24 and 0.43 respectively. Bxamination of the data in Table 5.3 indicates that the "field-of-view" results fall within the Iimits set by Equation 5.2 for zero and 100 per cent transmission, and, qualitatively, that the greatest effects occur whenever the greatest obscuration is to be expected.

The values given in Table 5.3 are lower than expected, even considering the effects of dust. This fact leads to the conclusion that an instrument designed to measure the thermal efficiency of a malear reapon should have a field of view such that the radius at the point of detonation will be no less than about two times the sum of the fire ball radius, estimated as above, and the maximan displacement of the center of the field of view from the point of detonation.

As one proceeds to more distant stations and correspondingly amaller fields of view, the instrunents would measure less and less of the total energy arriving at the station (more of this energy arrives as scattered radiation). However, since transmission values are determined as narronbeam results, accuracy of direct correction of the measured values to trae thermal efficiency would improve as the measuring angle was decreased. Of course, if the measurements are being made to determine the total thermal energy, direct and scattered, received by an adjacent plane surface, a
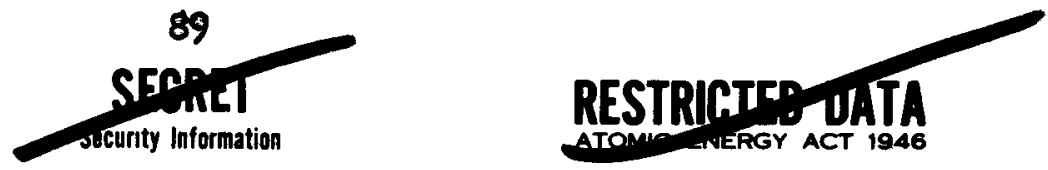


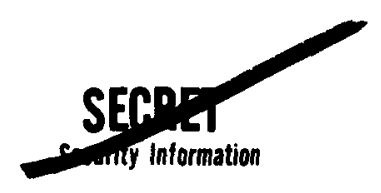

maximan field of view at all stations would be desirable.

Although additional data must be obtained before the reason for the low results with restricted field of view can be ascertained, one result of practical importance can be obtained from Table 5.3. It appears that any instrument designed to measure the total radiant energy should have a field of view such that the radius at the point of detonation will be greater than about three times the sum of the fire ball radius, calculated as above, and the estimated maximm displacement of the center of the field of view from the point of detonation.

\subsection{PASSIVE RECEIVERS}

The passive-receiver panels gave reasonably satisfactory results. In most cases the chosen effect was bracketed as expected and in some cases, where the energy was greater or less than anticipated, estimates of total energy could be made from the degree of effect on the last foil in the series of thicknesses. For the ground reflectance measurements, the energy ranges selected in designing the panels were usually too high and gave poor results, including one panel which produced no results. In addition, four panels from Shot 4) (those nearest ground zero) were not recoverable.

The agreement among panels at the same distance was better than 10 per cent at all but one station (at 18,000 ft on Shot 3) Howerer, agreement between different metals in the same panel was not as good. From Table 5.4 it can be seen that for the group-l panels the lead and tin agree with each other but differ from cadmium by about 14 per cent. Again, with the group-2 panels, silver and lead agree, while cadmiun differs by about 28 per cent. The metals used in the group-3 panels shon good agreement. Columns 3, 6, and 9 of Table 5.4, which give the standard deviations of the ratios of the energies from the different metals to the mean energy of the panel, indicate that the reproducibility of each metal is good. For this reason it appears that the disagreement between cadmium and the other metals is probably real and not due to random errors. No explanation can be given at the present time for this result.

The total energy values given in Tables 4.6 through 4.9 were corrected for atmospheric attenuation and plotted in Figs. 5.1 through 5.4 for comparison with the calorimeter results. Comparison of the foil and calorineter data in these figures shors one effect of the size of the tail in the thermal pulse. For Shots $I$ and 2, which had short tails the agreement between foil and calorimeter rosurts is good. For Shots 3 and 4, which had long tails relatively ineffective in producing damage to the folls, the calorimeter values were considerably higher than the foil values.
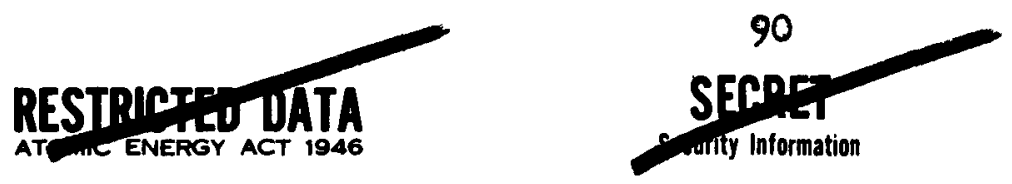


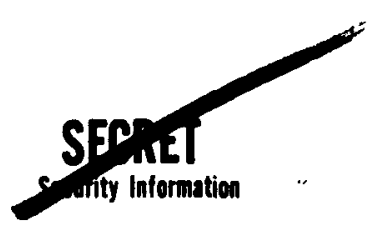

TABTE 5.4

Yean Ratios of Energy Values of Each Indicator to Energy Value of Panel

\begin{tabular}{|c|c|c|c|c|c|c|c|c|}
\hline \hline \multicolumn{3}{|c|}{ Group 1 } & \multicolumn{4}{c|}{ Group 2 } & \multicolumn{3}{c|}{ Group 3 } \\
\hline Metal & Mean Ratio & $\begin{array}{c}\text { Standard } \\
\text { Deviation }\end{array}$ & Metal & Mean Ratio & $\begin{array}{c}\text { Standard } \\
\text { Deviation }\end{array}$ & Metal & Mean Ratio & $\begin{array}{c}\text { Standard } \\
\text { Deviation }\end{array}$ \\
\hline $\mathrm{Cd}$ & 0.91 & 0.12 & $\mathrm{Cd}$ & 0.81 & 0.11 & $\mathrm{Cu}$ & 0.96 & 0.01 \\
$\mathrm{Sn}$ & 1.04 & 0.14 & $\mathrm{Ag}$ & 1.09 & 0.11 & $\mathrm{Ag}$ & 1.02 & 0.05 \\
$\mathrm{~Pb}$ & 1.05 & 0.12 & $\mathrm{~Pb}$ & 1.10 & 0.16 & $\mathrm{Ag}$ Strip & 1.03 & 0.04 \\
\hline
\end{tabular}

\subsection{SHIELDING OF RECORDER CABLES}

Because of lack of time and opportunity, no extensive or exhaustive Investigation has been made to date to find the cause of the umranted - lectrical signals in recorder cables that were so ovident during Operation BUSTER.

Operation TULBLER-SNAPPER afforded a limited opportunity to conduct a preliminary experiment. Four calorimeter circuits were installed with the electrical eircuits identical, except for the type of cable connecting the instrument to the recorder. The four cables were Ordnance cable, $*$ also used by USIRDL for all other recording circuits, Romex** in metallic armor, Romex without armor, and telephone wire.***

The results, which may well be complieated by the cross-feeding of the signal from one circuit to another, show that there was no pickup in the circuit using the Ordnance cable, but that the signal in the circuit using the telephone wire was of such magnitude that it caused the galvanometer to burn out. The circuits using Romex showed appreciable signals, although not enough to burn out the galvanometers. The signal in Ronex circuits may have been at least partially due to the adjacent telephone wire circuit.

* Navy type DHFTA-9 Ordnance cable consists of a twisted pair of insulated wres inside a water-tight rubber cover and a metallic, braided armor.

* Romex, Federal Spec. J-C-103, general purpose wire, consiats of tro No. 12 solid copper conductors insulated with plastic and a fibrous nonmetallic braid.

*** Telephone wire, Havy type MRI, consists of two stranded and twiated copper wires insulated with synthetic resin.

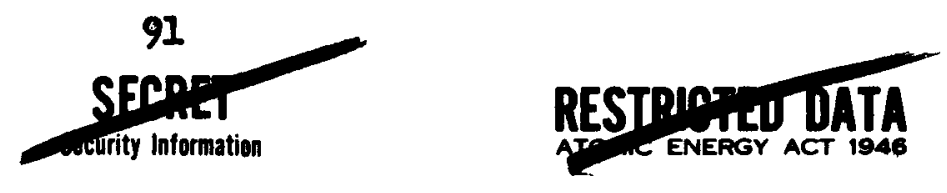




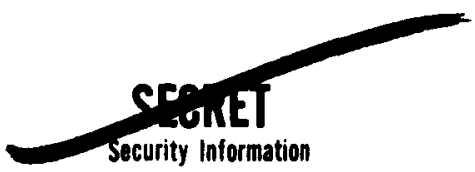

It is possible, with present knowledge, to eliminate the electrical pickup in nearly all cases by the use of extensive electrical shielding such as was used at Operation TUMBLER-SNAPPER. However, the data on hand are not sufficient to warrant any specific conclusions concerning the nature of the phenomenon.

\subsection{CONCLUSIONS}

While some small loss of data resulted from instrument failure, all objectives of this operation were fulfilled. Sufficient data were obtained to give confidence in the thermal energy-vs-distance and intensity-vs-time curves obtained for the various reapons. The spectral diatribution of the thermal energy probably was obtained to as great an accuracy as is possible through the use of the simple filter method employed. The data on energy rs elevation of measuring instrument gave a fair idea of the amount of local obscuration caused by thermal radiation. Although only preliminary nodels of the various radioneters were available for use in the field, these instruments gave good data concerning the intensity-vs-time relationship of the thermal output of the weapons. The passive receivers gave quite consistent date in most cases, and proved valuable for measurements where recorders were not available.

The major conclusions are summarized below:

1. Although the range of weapon glelds ( 1 - $30 \mathrm{KT}$ ) is not suffieiently great (because of uncertainties both in thermal and total jield) to completely rule out the possibility of constant thermal yield, the data reported here indicate a decrease in thermal efficiency with increasing weapon yield - ranging from about 44 per cent at 1 KT to about 34 per cent at $30 \mathrm{KT}$.

2. As expected, the thermal pulse lengthens with increasing vield. The time to second maximum ranges from about 100 msec for a 1 KT weapon to about 200 maec for a $30 \mathrm{kT}$ weapon. The range of weapon jields reported here is still not sufficiently great to allow accurate assessment of scaling lars.

3. The spectral measurements obtained curing this operation indicate appreciably more energy at wave lengths beyond 9500 \& (25 per cent) than was lound at Operation GREENHOUSE ( 10 per cent). Since the dust clouds produced loy the suriace detonation at GREDHOUSE obscured the later (cooler) pheses of the ilire ball this result is not surprising.

4. Care must be taken in interpreting data obtained near the ground, because measurements may be influenced by obscuration produced both by the shock wave and by effects of the thermal pulse itself. Obscuration realting from the thermal radiation precedes that produced by the shock wave, and is exemplified by "popcorning" of sand and by smoke produced by burning of ground litter.
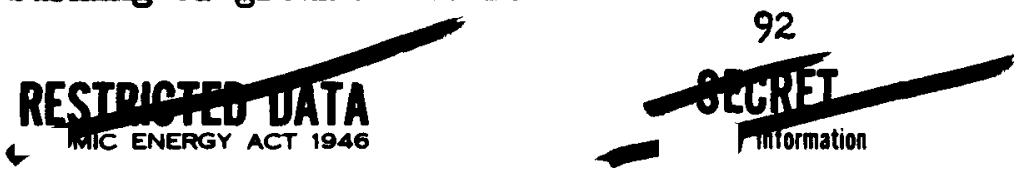


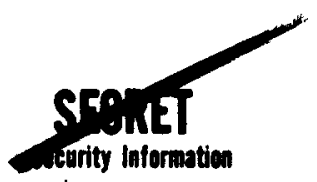

5. Because of uncertainties involved, it appears that any instrument designed to moasure the thermal efflciency of a weapon should have a field of view such that the radius at the point of detonation will be no less than about two times the sun of the fire-ball radius, calculated by scaling from values given in the Effects of Atomic Weapons, and the estimated maximum displacement of the center of the field of view from the point of detonation. On the other hand, instrumentation designed to measure the totel thermal energy, direct and scattered, received by an adjacent plane sample should have a field of view approaching $180^{\circ}$.

6. If properly interpreted, passive receiver panels can give reasonably satisfactory, self-consistent, results. For the 1 KrT reapons, with short thermal tails, the agreement between foil and calorimeter results is excellont. For the weapons of larger yield which have long thermal tails, relatively ineffective in producing damage to the foils, the calorimeter results are considerably higher than the foil values.

7. As can be seen from Appendix B, the thermal energy recelved by aircraft above the point of detonation may be considerably higher than that at the equivalent distances al ong the oround about 50 per cent

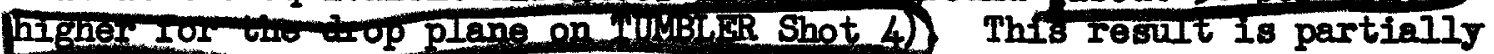

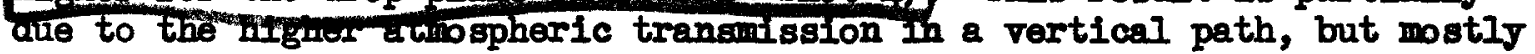
due to reflection of thermal energy by the ground.

However, it is to be emphasized that the results and conclusions are very Ifmited in their scope, and that great care mast be taken when applying them to other cases. The date presented pertain to air bursts over the Nevade desert, for certain particular altitudes of detonation, for a limited range of weapon sizes, and for particular types of weapons. Extrapolation to other conditions, particularly to weapons of meh lerger yields, me be extremely misleading.

\subsection{RECOANRADATIOAS}

On the basis of mosurements made at the TUMBLER-SIMPPER Operation and at previous operations the following recommendations are mede with regard to measurements which should be carried out at future tests of muclear weapons:

1. If the date obtained at previous tests are confirmed at Operation UPSHOI-KNOTHOLE, besic thermel moasurements should be made only at future tests in which the conditions are considerably different.

2. In order to determine the danger to aircraft from the thermal radiation, further above-griound measurements are necessary. Also, a theoretical and experimental program should be prosecuted in order to evaluate the contribution of radiation reflected from the surface of the earth and from clouds and to establish atmospheric attenuation along a non-horizontal path.

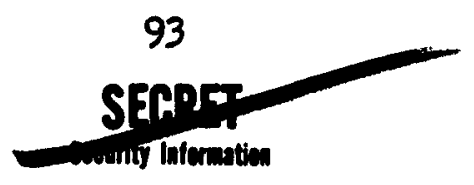




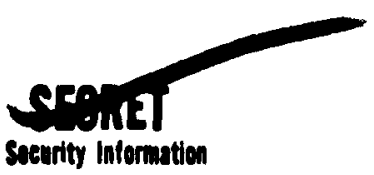

3. Further work should be done on the effect of field of view of the measuring instruments on the measurements, particularly at the larger fields of view.

4. For further rough estimates of the effectiveness of the thermal energy, passive receivers should be exposed at detonations which deviate appreciably in yield from those already measured.

5. Although the results are not compared in this report, certain discrepancies appear in comparing USNRDL date with data obtained by the Naval Research Laboratory. An attempt should be made to resolve these differences and to determine whether or not they are real. Assuming no obvious errors in either set of data, a further study of variation of the thermal pulse with distence from the detonation may be in order.

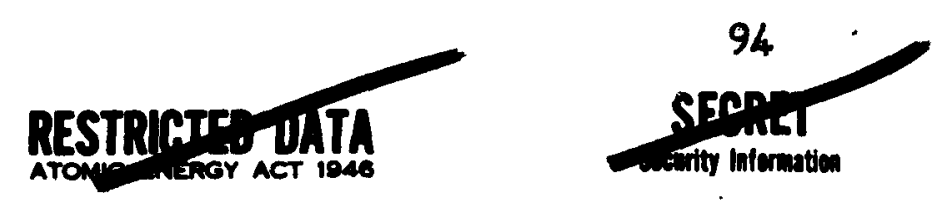




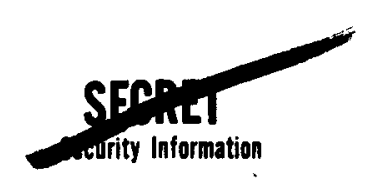

APPENDIX A

\section{MFASUREIENT OF THERMAL RADIATION INCIDENT UPON PARKGD ATHCRAFT}

USNRDL was asked to assist Project 3.1 personnel in the measurement of the thermal flux incident upon certain parked aircraft which were to be exposed to the effects of nuclear weapons for the purpose of determining damage repair criteria for the aircraft. Nino calorimeters were constructed and thermalir calibrated at DSRRIL. They were then delivered to the test site where they were installed and electrically calibrated by Project 3.1 personnel. A check electrical calibration was also made by USNRDL in the field.

Measurements were made at three locations ouring Shots 2, 3, and La Details concerning the location and mounting of the Instruments may be found in the Project 3.1 report.

Copies of the records were supplied to USARDL so that the data could be reduced along with similar data taken at Project 8.3 installations. The data presented in Table A.I were obtained by methods of analysis similar in all respects to those described for calorimeter data elsewhere in this report.

The total thermal energy-vs-distance data agree very well with USNRUL thermal line data under similar gircumstances, with the exception of the closest station on Shots 3 and 4 , and the 8,000-ft station on shot 4.7 The disagreement at the close stations is most probably due to Iocal aust and smoke obscuration.

Both Project 3.1 and Project 8.3 personnel analysed the data; and while the results obtained by the two groups agree fairly well, not all differences have been explained because time and distance considerations have prevented more than preliminary consultation to date. Care should be taken in application of these data, as the ralues are subject to change. 
TABTE A.I

TUMBLER-SNAPPER Calorimeter Data: (a) WADC Airplanes on Ground

\begin{tabular}{|c|c|c|c|c|c|c|c|c|}
\hline Station & $\begin{array}{l}\text { Slant Range } \\
\text { (ft) }\end{array}$ & $\begin{array}{c}\text { Half-angle of } \\
\text { Field of View } \\
\text { (deg) }\end{array}$ & Orientation(b) & $\begin{array}{c}\text { Elevation } \\
\text { (ft) }\end{array}$ & Ca1. No. & Filter & $\begin{array}{c}\text { Total Energy } \\
\text { under Filter } \\
(\mathrm{cal} / \mathrm{sq} \mathrm{cm})\end{array}$ & $\begin{array}{l}\text { Total Energy } \\
\text { Incident } \\
\text { (cal } / \mathrm{sq} \mathrm{cm)}\end{array}$ \\
\hline shot 27 & & & & & & & & \\
\hline$A$ & 2,490 & 45 & $A Z$ & 5 & $\operatorname{Red} 8$ & Quartz & \multirow{2}{*}{\multicolumn{2}{|c|}{$\begin{array}{l}\text { No record a vailable } \\
\text { No record available }\end{array}$}} \\
\hline$A$ & 2,490 & 45 & $A Z$ & 5 & $\operatorname{Red} 10$ & Quartz & & \\
\hline B & 8,060 & 45 & $A z$ & 5 & Black 8 & Quartz & 0.51 & 0.55 \\
\hline B & 8,060 & 45 & $\mathbf{A Z}$ & (c) & Black 9 & (d) & 0.14 & 0.15 \\
\hline $\mathbf{B}$ & 8,060 & 45 & $A Z$ & 5 & Black 10 & Quartz & 0.57 & 0.62 \\
\hline C & 10.538 & 45 & AZ & 5 & Gray 9 & Quartz & 0.26 & 0.28 \\
\hline C & 10,538 & 45 & $A Z$ & 5 & Gray 10 & Quartz & 0.30 & 0.33 \\
\hline $\boldsymbol{A}$ & 4,087 & 45 & $A z$ & 5 & Red 8 & Quartz & 27.3 & 29.7 \\
\hline $\boldsymbol{\Lambda}$ & 4,087 & 45 & $\Delta z$ & 5 & $\operatorname{Red} 10$ & Quartz & 27.2 & 29.6 \\
\hline B & 8,622 & 45 & $\mathbf{A Z}$ & 5 & Black 8 & Quartz & 10.3 & 11.2 \\
\hline B & 8,622 & 45 & $A Z$ & (c) & Black 9 & (d) & 3.2 & 3.5 \\
\hline B & 8,622 & 45 & $A Z$ & 5 & Black 10 & Quartz & 7.8 & 8.5 \\
\hline$c$ & 10,988 & 45 & $A Z$ & 5 & Gray 9 & Quartz & 5.9 & 6.4 \\
\hline C & 10,988 & 45 & $A Z$ & 5 & Gray 10 & Quartz & 5.5 & 6.0 \\
\hline $\boldsymbol{A}$ & 2,508 & 45 & $\mathbf{A Z}$ & 5 & Red 8 & Quartz & $\cdots$ & $\ldots$ \\
\hline $\mathbf{A}$ & 2,508 & 45 & $A Z$ & 5 & Red 10 & Quartz & 33.4 & 36.3 \\
\hline A4 & 3,960 & 45 & $\mathbf{A Z}$ & 5 & Black 8 & Quartz & 24.8 & 27.0 \\
\hline$\wedge 4$ & 3,960 & 45 & $\mathbf{A Z}$ & (e) & Black 9 & (d) & 19.7 & 21.4 \\
\hline 14 & 3,960 & 45 & $\mathbf{A Z}$ & 5 & Black 10 & Quartz & 24.9 & 27.1 \\
\hline D & 7,890 & 45 & AZ & 5 & Gray 9 & Quartz & 6.1 & 6.6 \\
\hline B & 7,890 & 45 & $\mathbf{A Z}$ & 5 & Gray 10 & Quartz & 7.1 & 7.7 \\
\hline
\end{tabular}

(a) Not corrected for atmospheric attenuation.

(b) $\mathbf{~} \mathrm{Z}$ = Calorineter aligned toward air zero.

(c) Inside B-17.

(d) Quartz and windshield.

(e) Inside $\mathrm{F}-47$. 


\section{MEASUREIENT OF THERMAL RADIATION IITIDENT ON DROP AIBCRAFI}

The 4925 th Air Bombardment Group asked USIRDL to assist in an attempt to measure the thermal radiation incident upon the drop aircraft.

Three standard disk ealorimeters, of the type described elsewhere in this report, were delivered to Capt. 0. R. Hill, USAF, Project Officer for the drop aircraft, at the test site. The calorimeters and the recorders were then mounted in the aircraft under his direction.

Calibration was carried out by USNRDL personnel at the Indian Springs Air Force Base on two occasions, and also when, at the conclusion of the operation, the complete circuits were returned to USWROL. Data were recuced and analyzed by the same procedure described in the body of this report.

Table B.l shows the results of the measurements taken on the B-50 aircraft in flight.

TABLE B.I

TUMLER-SWAPPER Calorimeter Data: (a) B-50 in Flight over Detonation

\begin{tabular}{|c|c|c|c|c|c|c|c|c|}
\hline Shot & $\begin{array}{c}\text { Slant Range } \\
\text { (ft) }\end{array}$ & $\begin{array}{c}\text { Half-angle of } \\
\text { Field of View } \\
\text { (deg) }\end{array}$ & Orientation(b) & $\begin{array}{c}\text { Elevation } \\
\text { (ft) }\end{array}$ & cal. No. & Filter & $\begin{array}{l}\text { Total Energy } \\
\text { under Filter } \\
(\mathrm{cal} / \mathrm{sq} \mathrm{cm})\end{array}$ & $\begin{array}{l}\text { Total Energy } \\
\text { Incident } \\
\text { (cal/sq cm) }\end{array}$ \\
\hline 1 & 18,700 & 45 & AZ & 19,000 & Brass 2 & Quartz & \multirow{3}{*}{\multicolumn{2}{|c|}{$\begin{array}{l}\text { No energy detected } \\
\text { No energy detected } \\
\text { No energy detected }\end{array}$}} \\
\hline & 18,700 & 45 & $\mathbf{A z}$ & 19,000 & Brass 5 & Quartz & & \\
\hline & 18,700 & 45 & AZ & 19,000 & Erass 7 & Quartz & & \\
\hline 2 & 18,020 & 45 & $\mathbf{A Z}$ & 19,000 & Trass 2 & Quartz & \multicolumn{2}{|c|}{ No energy detected } \\
\hline & 18,020 & 45 & $\mathbf{A z}$ & 19,000 & Brass 5 & Quartz & \multicolumn{2}{|c|}{ No energy detected } \\
\hline & 18,020 & 45 & $\mathbf{A Z}$ & 19,000 & Brass 7 & Quartz & No energ & detected \\
\hline 3 & Not & 45 & $\mathbf{A Z}$ & Not & Frass 2 & Quartz & \multirow{3}{*}{\multicolumn{2}{|c|}{$\begin{array}{l}\text { Timing fallure } \\
\text { Timing fallure } \\
\text { Timing fallure }\end{array}$}} \\
\hline & Avail- & 45 & $\mathbf{A Z}$ & Avail- & Frass 5 & Quartz & & \\
\hline & able & 45 & $\mathbf{A Z}$ & able & Brass 7 & Quartz & & \\
\hline \multirow[t]{3}{*}{4} & 18,885 & 45 & $\mathbf{A Z}$ & 19,800 & Frass 2 & Quartz & 2.2 & 2.3 \\
\hline & 18,885 & 45 & $\mathbf{A Z}$ & 19,800 & Brass 5 & Quartz & 2.0 & 2.1 \\
\hline & 18,885 & 45 & $\mathbf{A Z}$ & 19,800 & Fass 7 & Quartz & \multicolumn{2}{|c|}{ No energy detected } \\
\hline
\end{tabular}

(a) Hot corrected for atmospheric attenuation.

(b)

AZ = Calorimeter aligned toward air zero.

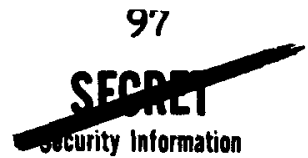




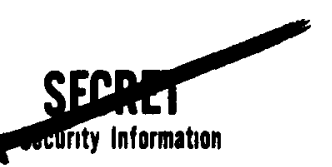

Though a small amount of energy was expected on Shots 1 and 2, no detectable energy was received. This could be due to errors in ariznment of the calorimeters or to condensation on the quartz filter, but no certain explanation has yet been found. No readings were obtained on shot 3, owing to a failure in the starting sequence for the recorder. On suow of the three calorimeters operated properly and gave values in good agreement with each other. These values have been raised 5 per cent to correct for the changes in the properties of the measuring system at the lover temperatures oncountered at high altitudes.

In order to compare the values measured from the $B-50$ with those measured at the ground installations, it is necessary to correct for the atmospheric attenuation. Since no measurements were made of the transmission in a rertical direction, an estimate of this value was obtained from the measured 95-per-cent-per-mile transmission for a horizontal path by assuming that the attenuation coefficient is proportional to the atmospheric density and that the change of density with altitude was that of a standard atmosphere ]. This results in an estimated average atmospheric transmission of 96.3 per cent per mile for the nearly vertical path between the point of detonation and the B-50. As the total correction for the atmospheric attenuation is less than 15 per cent, uncertainties in the value of the absorption coefficient should cause less than 5 per cent error in the energy values.

Using the value of atmospheric transmission given above, the energy value at the plane is about 50 per cent higher than the value on the surface at the same distance. This is most probably due to the reflection of energy from the ground. Preliminary calculations on the amount of onergy reflected from the ground, using a value of 45 per cent for the reflectivity of the soil (Appendix C), indicate that a value of 50 per cont is not unreasonable.

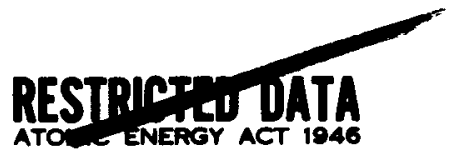




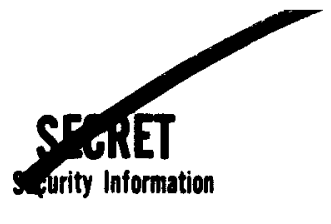

\section{APPENDIX C}

\section{REPLECTIVITY OF MEVADA PROVING GROUNDS SOIIS}

Due to the interest in the amount of thermal radiation absorbed by the ground during the detonation of a nuclear weapon, it seemed advisable to measure the reflectivity of the soil in the areas where thermal radiation and air temperatures were being measured.

Measurements of the reflagtivity of the soil, using the oun as a souran were made onl5 lay 1952 between hours 1130 and 1230, PDI. (in the

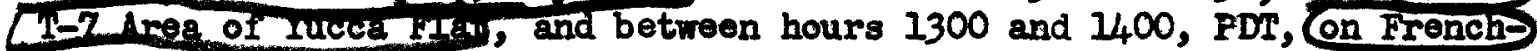
man Iakes Ithe Fellectometer used was made at USNRDL and has a fleld of view of half-angle $3^{\circ}$. The receiver consists of a Weaton Photronic cell, Type $856 \mathrm{RR}$. The instrument makes use of a test plate smoked with magnesiun exide as a reflection standard, and thus all reflection measurements are expressed as percentages of the reflectivity of the magnesium oxide.

Measurements were made, while the sun was noar apparent noon, wlth the receiver viewing the ground vertically, and at $10^{\circ}$ intervals up to $700 \mathrm{E}$ and $70^{\circ} \mathrm{W}$ from the vertical. The axis of the receiver was at all times in the vertical east-west plane. The angle between the zenith and the sun's rays was approximately 200. The measurements were made for areas in front of towers upon wich Project 8.2 and 8.3 instruments were mounted. The area on the ground seen by the instrument was approximately $10 \mathrm{sq}$ in. when the instrument was normal to the ground. The results of these measurements are tabulated in Table C.I. The $70^{\circ}$ measurements have questionable validity because the area viewed by the receiver approached the area of the standard plate.

These data are of value in correlating the amount of energy absorbed by the ground with the amount of energy incident, and in determining the increase in thermal energy received by objects due to ground reflection of the thermal pulse.

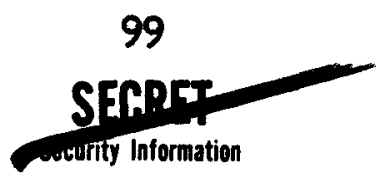


Soeutity Intomingurs

TABLE C.I

Reflectivity of Soils

\begin{tabular}{|c|c|c|c|c|c|c|}
\hline \multirow{2}{*}{$\begin{array}{c}\text { Angle } \\
\text { of } \\
\text { Observation(a) }\end{array}$} & \multicolumn{6}{|c|}{ Reflectivity Relative to Magnesium Oxide } \\
\cline { 2 - 7 } 70E & $7-210$ & $7-208$ & $7-206$ & F-202 & F-208 & F-210 \\
\hline $60 \mathrm{E}$ & 53 & 50 & 53 & 70 & 76 & 75 \\
$50 \mathrm{E}$ & 47 & 48 & 50 & 66 & 67 & 69 \\
$40 \mathrm{E}$ & 45 & 46 & 46 & 62 & 62 & 65 \\
30E & 44 & 46 & 45 & 60 & 61 & 64 \\
$20 \mathrm{E}$ & 44 & 45 & 44 & 58 & 60 & 63 \\
$10 \mathrm{E}$ & 44 & 45 & 43 & 58 & 59 & 62 \\
0 & 44 & 45 & 43 & 59 & 58 & 62 \\
$10 \mathrm{~W}$ & 44 & 45 & 43 & 58 & 58 & 62 \\
$20 \mathrm{~W}$ & 44 & 45 & 42 & 58 & 58 & 62 \\
30W & 42 & 44 & 42 & 58 & 59 & 62 \\
$40 \mathrm{~W}$ & 41 & 45 & 42 & 56 & 59 & 63 \\
$50 \mathrm{~W}$ & 41 & 45 & 42 & 57 & 59 & 63 \\
$60 \mathrm{~W}$ & 41 & 46 & 42 & 58 & 62 & 64 \\
$70 \mathrm{~W}$ & 43 & 48 & 45 & 62 & 66 & 67 \\
\hline & 47 & 51 & 49 & 66 & 71 & 71 \\
\hline
\end{tabular}

(a) Measured from vertical. 
